\title{
WHAT WORKS IN HUMAN RigHTS INSTITUTIONS?
}

\author{
By Katerina Linos ${ }^{*}$ and Tom Pegram ${ }^{\dagger}$
}

This is the final typeset and copyedited PDF version. The article should be cited as:

\author{
Katerina Linos and Tom Pegram, 'What Works in Human Rights Institutions?' The American \\ Journal of International Law, vol. 112, no. 3, July 2017, pp. 1-61.
}

\begin{abstract}
Since 1993, the United Nations has promoted national human rights institutions (NHRIs); these have spread to almost 120 countries. We assess what makes NHRIs effective, using quantitative and qualitative methods. We find that formal institutional safeguards contribute greatly to NHRI efficacy even in authoritarian and transition regimes. Complaint-handling mandates are particularly useful because they help NHRIs build broad bases of support. Our findings show how international organizations can wield great influence with soft tools such as recommendations and peer-review mechanisms.
\end{abstract}

* Professor of Law, University of California, Berkeley - School of Law. Correspondence: klinos@berkeley.edu. We thank Ryan Goodman and Derek Jinks for their extraordinary help in collecting NHRI data. For very helpful comments we thank Kenneth Abbott, Carlos Alza, Gabby Blum, Anu Bradford, Curtis Bradley, Rachel Brewster, Brian Burdekin, Richard Carver, Fernando Castañeda, Adam Chilton, Alberto Coddou, Colm O'Cinneade, John Crabtree, Christopher Elmendorf, Laurel Fletcher, Stavros Gadinis, David Gartner, Fabrizio Gilardi, Tom Ginsburg, Jack Goldsmith, Bert Huang, Ryan Goodman, Andrew Guzman, Laurence Helfer, Courtney Hillebrecht, Derek Jinks, Katrien Meuwissen, Abraham Newman, Chris Robertson, Eric Posner, Chris Sidoti, Kathryn Sikkink, Beth Simmons, Duncan Snidal, Holger Spamann, Matthew Stephenson, Erik Voeten, Laurence Whitehead, and Mark Wu. We are also very grateful to the five anonymous reviewers for their feedback on this piece. We would like to thank Caroline Brandt, Sonakshi Kapoor, Kim Twist, and Lauriane Wolfe for excellent research assistance. We are very grateful to the many individuals who gave of their time during the course of our investigation. We would also like to thank all of the participants at workshops held at University College London, University of California, Berkeley, at the University of Chicago, at Duke University, at Harvard University, at the University of Oxford and the University of Zurich. We also thank the Berkeley Hellman Fund, the Berkeley Miller Center, and the Berkeley Jean Monnet Center for Excellence for their generous financial support.

$\uparrow$ Senior Lecturer in Global Governance, Department of Political Science/School of Public Policy at University College London. Correspondence: t.pegram@ucl.ac.uk. 


\section{INTRODUCTION}

Human rights treaties articulate ambitious international standards, but in many parts of the world, domestic practices lag far behind. In the post-World War II period, the vast majority of governments across the world adopted the language of fundamental rights, ${ }^{1}$ signed and ratified key international human rights treaties; ${ }^{2}$ incorporated equality provisions in their constitutions; ${ }^{3}$ and developed domestic jurisprudence giving particular shape to these rights. However, human rights practices on the ground are at best uneven. ${ }^{4}$

To bridge the gulf between international law and domestic practices, in the early 1990s, the United Nations started promoting National Human Rights Institutions (NHRIs), independent national agencies specifically designed to protect and promote human rights. ${ }^{5}$ The UN defines an NHRI very broadly, as "a body which is established by a Government under the constitution, or by law or decree, the functions of which are specifically designed in terms of the promotion and protection of human rights." calling on all states to adopt an NHRI, provided a template for NHRI design and precipitated institutional reforms in dozens of countries. ${ }^{7}$ NHRIs spread very rapidly across diverse political systems, from an estimated twenty NHRIs in 1990 to approximately 121 active NHRIs in 2017, with more on the way. ${ }^{8}$

NHRIs are undoubtedly an important example of global administrative law and networked regulation more generally. ${ }^{9}$ As NHRIs take center stage as a possible "missing link" in a transnational human rights regime, increasing attention is being paid to how they actually work, and crucially, when and why they matter. ${ }^{10}$ Pioneering work by practitioners, ${ }^{11}$

1 See John Boli \& George M. Thomas, Constructing World Culture: International NONGOVERNMENTAL ORGANIZATIONS SINCE 1875 (1999).

${ }^{2}$ Beth A. Simmons, Mobilizing for Human Rights: International LaW in Domestic Politics 36-54 (2009).

${ }^{3}$ See Zachary Elkins, Tom Ginsburg \& Beth A. Simmons, Getting to Rights: Treaty Ratification, Constitutional Convergence, and Human Rights Practice, 54 HARV. InT'L L.J. 61 (2013); Francisco O. Ramirez, Yasemin Soysal \& Suzanne Shanahan, The Changing Logic of Political Citizenship: Cross-National Acquisition of Women's Suffrage Rights, 1890 to 1990, 62 AM. SOC. REV. 735 (1997).

${ }^{4}$ See, e.g., Emilie M. Hafner-Burton \& Kiyoteru Tsutsui, Justice Lost! The Failure of International Human Rights Law to Matter Where Needed Most, 44 J. PeACE ReS. 407 (2007); Oona A. Hathaway, Do Human Rights Treaties Make a Difference?, 111 YALE L.J. 1935 (2002); Christopher J. Fariss, Respect for Human Rights Has Improved Over Time: Modeling the Changing Standard of Accountability, 108 AM. POL. SCI. REV. 297 (2014); Ryan Goodman \& Derek Jinks, Measuring the Effects of Human Rights Treaties, 14 EUR. J. INT'L L. 171 (2003).

5 U.N. CENTRE FOR Human Rights, NATIONAL Human Rights Institutions: A HandBoOK ON THE Establishment and Strengthening of National Human Rights Institutions for the PROMOtion AND Protection of HuMAN Rights, U.N. SALES No. E.95.XIV.2 (1995).

${ }^{6} I d$., para 39.

${ }^{7}$ See Katerina Linos \& Thomas Pegram, The Language of Compromise in International Agreements, 70 INT'L ORG. 587 (2016).

${ }^{8}$ See Global Alliance of National Human Rights Institutions (GANHRI), ICC Accreditation, Office of the High $\begin{array}{lllll}\text { Commissioner for } & \text { Human } & \text { (OHCHR), ats }\end{array}$ http://nhri.ohchr.org/EN/AboutUs/GANHRIAccreditation/Pages/default.aspx; see also Katerina Linos \& Tom Pegram, Architects of Their Own Making: National Human Rights Institutions and the United Nations, 38 HuM. RTS. Q. 1109, 1110 (2016).

9 See Benedict Kingsbury, Nico Krisch \& Richard B. Stewart, The Emergence of Global Administrative Law, 68 LAW \& CONTEMP. PROBS. 15-61 (2005).

${ }^{10}$ Linos \& Pegram, The Language of Compromise, supra note 7 at 597-605. 
interventions by international non-governmental organizations (INGOs), ${ }^{12}$ recent scholarly contributions, ${ }^{13}$ and careful case study work on individual cases ${ }^{14}$ all suggest that at least some NHRIs are contributing significantly to the improvement of human rights in their countries. NHRIs have assisted torture victims in seeking redress before domestic and international courts, stewarded truth and reconciliation processes, improved legislation protecting vulnerable groups, mediated social conflicts, and mobilized public opinion on environmental rights. ${ }^{15}$ Some governments invested significant resources in building these institutions; case studies suggest that some employ hundreds of staff members, have dozens of regional offices, and operate on multimillion dollar annual budgets. ${ }^{16}$ Indeed, the one existing large-N study of NHRIs also offers reason for hope, as it concludes that adopting an NHRI reduces physical integrity violations. ${ }^{17}$ But in other countries, there are significant concerns that states built "sham" NHRIs in response to international pressure, without granting them the powers to carry out their monitoring tasks. ${ }^{18}$

To understand what makes some NHRIs particularly effective, and others less so, we start by focusing on formal institutional design safeguards. These formal safeguards include provisions intended to guarantee the body's independence (e.g., provisions for the appointment and removal of NHRI leaders), as well as provisions outlining specific tasks that fall within an NHRI's mandate (e.g., provisions that the NHRI can visit prisons or receive individual complaints). We term these features "safeguards" because they can help protect an active NHRI from efforts to change its leadership or structure, as well as from allegations that it exceeded its mandate. We term these features "formal" because they are found in writing in legal

${ }^{11}$ See, e.g., Richard CARVER, Performance \& Legitimacy: NATiOnal Human Rights Institutions (2001) [hereinafter CARVER 2001]; RICHARD CARVER, ASSESSING THE EFFECTIVENESS OF NATIONAL HUMAN RIGHTS INSTITUTIONS (2005) [hereinafter CARVER 2005]; BRIAN BURDEKIN \& JASON NAUM, NATIONAL HUMAN RIGHTS INSTITUTIONS IN THE ASIA-PACIFIC REGION (2007).

12 Amnesty International, NHRIs: Recommendations for Effective Protection and Promotion of Human Rights, AI Index: IOR 40/007/2001 (Oct. 2001), available https://www.amnesty.org/download/Documents/128000/ior400072001en.pdf.

13 Human Rights, State Complance, and Social Change: Assessing National Human Rights Institutions (Ryan Goodman \& Thomas Pegram eds., 2012); SoniA CARDENAS, Chains of JusticE: ThE Global Rise of STATE InstituTIONS FOR HuMAN Rights (2014); Sarah Spencer \& Colin Harvey, Context, Institution or Accountability? Exploring the Factors that Shape the Performance of National Human Rights and Equality Bodies, 42 POL. \& POLITICS 89-107 (2014).

${ }^{14}$ See Shedrack C. Agbakwa \& O.C. Okafor, On Legalism, Popular Agency and 'Voices of Suffering': The Nigerian National Human Rights Commission in Context, 24 HuM. RTS. Q. 662 (2002); Fredrik Uggla, The Ombudsman in Latin America, 36 J. LATIN AM. STUD. 423 (2004); Pilar Domingo, Weak Courts, Rights and Legal Mobilization in Bolivia, in COURTS AND SOCIAL TRANSFORMATION IN NEW DEMOcRACIES: AN INSTITUTIONAL VOICE FOR THE POOR? 233 (Roberto Gargarella, Pilar Domingo \& Theunis Roux eds., 2006); Jodi Finkel, Explaining the Failure of Mexico's National Commission of Human Rights (Ombudsman's Office) After Democratization: Elections, Incentives, and Unaccountability in the Mexican Senate, 13 HUM. RTS, REV. 473 (2012).

15 See Agbakwa \& Okafor, supra note 14; Domingo, supra note 14; Evgeny Finkel, The Authoritarian Advantage of Horizontal Accountability: Ombudsmen in Poland and Russia, 44 COMP. PoL. 291 (2012).

${ }^{16}$ See Thomas Pegram, National Human Rights Institutions in Latin America: Politics and Institutionalization, in Human Rights, State Compliance, AND Social CHANGE, supra note 13, at 210, 210-40.

17 See Wade M. Cole \& Francisco O. Ramirez, Conditional Decoupling: Assessing the Impact of National Human Rights Institutions, 1981 to 2004, 78 AM. SOC. REV. 702 (2013).

18 Simmons, supra note 2; Human Rights Watch, Protectors or Pretenders? Government Human Rights Commissions in Africa 14 (Jan. 1, 2001); CARVER 2001, supra note 11 at 59-63; Thomas Pegram \& Ryan Goodman, Introduction: National Human Rights Institutions, State Conformity, and Social Change, in HuMAN RIGHTS, STATE COMPLIANCE, AND SOCIAL CHANGE, supra note 13, at 1, 18. 
documents - typically in an NHRI's charter, which can in turn form part of a national constitution, legislation, or executive decree. We thus contrast formal safeguards with informal arrangements, oral agreements, and societal norms that could also contribute to institutional effectiveness. Based on extensive consultation with scholars and practitioners, we compiled a list of twenty-two such features that could contribute to NHRI effectiveness, and outline how each could operate in theory in Part I below.

We focus on formal design because a large literature in administrative law suggests that agencies with formal safeguards are often more effective than agencies that lack them. Administrative law scholarship suggests that politically independent bodies can potentially facilitate expert and nonpartisan decision making, stabilize policymaking against electoral cycle volatility, and protect politically disadvantaged minorities. ${ }^{19}$ In addition, institutional design safeguards provide the international community - the principal backer of NHRIs - with an important lever of influence. The UN can neither directly appoint NHRI staff members nor contribute significantly to NHRI budgets, but the UN has strongly recommended specific institutional safeguards, and has granted speaking rights and special status to select NHRIs. ${ }^{20}$ Finally, NHRI practitioners suggest and case study authors argue that certain configurations of safeguards are critical to the success of these bodies. ${ }^{21}$

That said, we need to learn a great deal more about which institutional design rules will matter, and under what circumstances. After all, designing effective institutions is challenging in any context; the compliance gap separating formal rules from their implementation on the ground has motivated a vast institutional literature across law, political science, sociology, and economics. ${ }^{22}$ The gap between formal design choices and organizational effectiveness could be especially severe in the human rights context. This is because NHRIs are intended to work as checks on the government that set them up; indeed, many countries set up NHRIs in response to severe international criticism of their human rights practices, and authoritarian leaders might be reluctant to set up too strong a monitoring body. ${ }^{23} \mathrm{~A}$ main theoretical contribution of our project is to marry general administrative law theories - often developed with a focus on industrialized

19 See David E. Lewis, Presidents and the Politics of Agency Design: Political Insulation in the United States Government Bureaucracy 1946-1997 (2003); David A. Hyman \& William E. Kovacic, Why Who What Matters: Governmental Design and Agency Performance, 82 GEO. WASH. L. REV. 1446 (2014); STEPHAN S. Haggard \& Robert Kaufman, The Politics of ECONOMic AdJustment: InTERnAtional Constraints, Distributive Conflicts And the State (1992); Matthew McCubbins, Roger G. Noll \& Barry R. Weingast, Structure and Process, Politics and Policy: Administrative Arrangement and the Political Control of Agencies, 75 VA. L. REV. 431 (1989); Jody Freeman \& Jim Rossi, Agency Coordination in Shared Regulatory Space, 125 HARV. L. REV. 1131 (2012).

${ }^{20}$ More specifically, "A" status National Human Rights Institutions (NHRIs) have speaking rights within the Human Rights Council; an NHRI peer review network, the Global Alliance of National Human Rights Institutions (GANHRI) awards "A" status. See infra Part II.A.1. for details. See also Linos \& Pegram, The Language of Compromise, supra note 7 (indicating how the UN Paris Principles shaped the establishment of dozens of NHRIs ) and Linos \& Pegram, Architects of Their Own Making, supra note 8 (explaining how the UN has included NHRIs in treaty mechanisms).

${ }^{21}$ CARVER 2001, supra note 11, at 111-12.

${ }^{22}$ See, e.g., Terry M. Moe, The New Economics of Organization, 28 AM. J. POL. SCI. 739 (1984); Kingsbury, Krisch \& Stewart, supra note 9; Paul Pierson, Not Just What, but When: Timing and Sequence in Political Processes, 14 STUD. AM. Pol. DeV. 72 (2000); Steven Levitsky \& María Victoria Murillo, Variation in Institutional Strength, 12 ANN. REV. POL. SCI. 115 (2009).

${ }_{23}$ See Dongwook Kim, International Nongovernmental Organizations and the Global Diffusion of National Human Rights Institutions, 67 INT'L ORG. 505 (2013). 
settings - with specific intuitions from the NHRI community, and to develop and test a range of theoretical conjectures.

In Part I, we develop three interconnected theoretical arguments, about whether, when, and why institutional safeguards matter. To develop theoretical claims, we draw heavily on the administrative law and politics literature, which is well-developed for industrialized settings, and in particular the United States, and build on it to explain how particular claims might or might not apply to the human rights setting in diverse types of countries. First, we theorize that NHRIs with more independence guarantees, with a broader formal mandate-including investigatory and promotional powers - and with greater inclusiveness provisions are more effective than those that lack these safeguards. Our second hypothesis is that context matters: formal institutional design is most likely to translate directly to improved outcomes in stable democracies that follow the rule of law, but should still influence decisions in authoritarian and transition regimes. Third, we try to explore theoretically why institutional design should matter for NHRI effectiveness, even in such challenging regime settings. We theorize that institutional design safeguards could influence NHRI priority-setting and staffing choices, shape modes of resistance toward independent agencies tasked with holding government to account, and contribute to positive (or negative) feedback loops, linking the NHRI to civil society and the media over time.

We then explore these claims empirically to understand variation in the effectiveness of NHRIs around the world. To offer the first systematic assessment of NHRI effectiveness, we triangulate across three types of measures. To assess NHRI effectiveness quantitatively, we start with the grade awarded to NHRIs by an NHRI peer review network. We supplement this grade with original expert survey data, in which thirty-six experts from around the world assessed the effectiveness of NHRIs with which they were familiar. Following past best practice in scholarship on administrative agencies, ${ }^{24}$ both our quantitative measures focus on the agency itself, rather than capturing country-level human rights performance that could be attributed to the executive, the legislature or the judiciary, among others. We supplement these aggregate measures of effectiveness with detailed qualitative case studies that can separate out different dimensions of agency effectiveness, by assessing, for instance, whether an NHRI was effective at resolving individual complaints but less effective at triggering legislative change, or perhaps attracted extensive publicity to certain human rights issues while shying away from matters the executive considered sensitive. Each of these measures has important advantages and limitations, which we develop below. Nevertheless, by collecting data that is much more extensive than prior work in comparative administrative law, and by triangulating across different types of source materials, we make significant progress on the question of agency effectiveness.

In Part II, we present quantitative analyses. To conduct quantitative analyses, we compiled an original dataset of twenty-two institutional design features of NHRIs in 107 countries. This reflects significant improvement on prior quantitative work that compares the presence of an NHRI to the absence of such a body, but has less to say about different types of NHRIs. ${ }^{25}$

In Part III, we assemble our case study evidence to assess the plausibility of various causal propositions and probe inductively the impact of specific design mechanisms on NHRI

\footnotetext{
${ }^{24}$ Chris Hanretty \& Christel Koop, Political Independence, Accountability, and the Quality of Regulatory Decision-Making, COMP. POL. STUD. (first pub. March 28, 2017), available at http://journals.sagepub.com/doi/10.1177/0010414017695329.

${ }^{25}$ See id.; Cole \& Ramirez, supra note 17.
} 
behavior and outcomes. ${ }^{26}$ To assess the importance of investigatory safeguards we compare Peru's NHRI, which has such mechanisms, with Chile's NHRI, which lacks such safeguards. To assess the importance of promotional safeguards, we compare Malaysia's NHRI which has this formal mandate, to the Philippine NHRI, which lacks many of these safeguards. Our case studies draw on over a decade of fieldwork, and are built on a wealth of original documentary sources and evidence. In addition, they are structured to follow best practices in qualitative methodology on case selection and within case analysis.

In both our quantitative and qualitative analyses, we find that NHRIs with formal safeguards are more effective than those that lack these features, especially among democratic states. We find that even in transitional and authoritarian settings, formal safeguards can have important intermediate effects: guiding initial NHRI staffing and activity choices, shaping the kinds of resistance that outspoken NHRIs are likely to confront, and helping to build media and societal support over time. In particular, NHRIs with strong investigatory capabilities, starting with the ability to receive and process individual complaints, are more effective than NHRIs without these features. In the short term, complaint-handling allows the NHRI to help address individuals' issues, while in the longer term, complaint-handling powers allow NHRIs to build community support based on their public profile as accessible and accountable institutions, and thus resist budget cuts and other challenges.

As we outline in our conclusion, these findings have important implications for many debates. We contribute to administrative law debates by exploring when and why formal institutional design corresponds to improved outcomes, even in developing countries. We show that formal mandates - which tend to be relatively stable over time-inform both the internal workings of these agencies, as well as how they relate to their external political and institutional environment. ${ }^{27}$ Over time, initially empowered NHRIs can more easily build coalitions and positive feedback cycles. We also contribute to human rights debates, by showing how NHRIs can serve as the missing link connecting ambitious international standards with practices on the ground across diverse regime settings. More specifically, we show that individual complainthandling powers - a controversial issue within the NHRI community-are linked to organizational effectiveness in a broad range of settings. We also help advance international law methodology, by combining cutting-edge quantitative and qualitative techniques, and showing how interviews and expert surveys can be effectively incorporated into legal scholarship. Finally, we contribute to debates on international organization efficacy, demonstrating how some of the limited levers that the United Nations has at its disposal-General Assembly resolutions, peer review, and participation rights - can translate into unexpected policy shifts at the national level.

\section{THEORETICAL CONJECTURES ON NHRI EFFECTIVENESS}

We seek to address two interrelated questions: whether NHRI institutional design matters, and if so, how. In this section, we develop theoretical claims; we turn to their empirical testing in Parts II and III. Whether, when, and why formal design matters are core questions for administrative law and public administration scholarship. Bureaucratic independence and

\footnotetext{
${ }^{26}$ See Alexander L. George \& Andrew Bennett, CASE Studies And TheOry Development in the Social SCIENCES (2005).

27 For a similar inquiry into the impact of external environmental factors on the variable authority of international courts see Karen J. Alter, Laurence R. Helfer \& Mikael Rask Madsen, How Context Shapes the Authority of International Courts, 79 LAW \& CONTEMP. PROBS. (2016).
} 
autonomy are emphasized in this scholarship. Formal design features intended to increase autonomy include provisions that make it hard to reverse agency decisions, replace agency personnel, and curtail the agency's mandate. ${ }^{28}$ However, much of this research agenda has principally focused on the United States and on industrialized world bureaucratic structures, so it is important to carefully consider how to adapt theories for the rest of the world.

Case studies of NHRIs yield a generally positive, but mixed picture, of these bodies' contributions. The one existing large-N study of NHRI effects also offers us some optimism: it finds that countries which adopted NHRIs have seen a persistent improvement in their physical integrity outcomes. ${ }^{29}$ We build on this important work by analyzing NHRI institutional design in much greater detail. Qualitative case studies suggest formal institutional design safeguards matter both in stable democracies, and in less democratic regimes. For example, the fact that the British Equality and Human Rights Commission was set up by legislation (rather than executive decree) helped ward off credible threats of dissolution in 2012 by a government which viewed it as a "relic of the past." 30 In Russia, when an independent and effective ombudsman confronted former President Boris Yeltsin over violations in Chechnya, the office persisted (although the head of the office was replaced), in part because the office was constitutionally entrenched. ${ }^{31}$

NHRIs are organized in highly diverse ways. Some are highly pluralistic, made up of multi-member commissions, while others are unitary, composed of a single ombudsman head. Some NHRIs handle complaints and have robust investigative powers, some serve principally an advisory function to the legislative and executive branches and others mainly conduct research. Some NHRIs have legal prerogatives, some have none at all. How, if at all, do these differences matter?

In the paragraphs that follow, we draw on general administrative law scholarship that emphasizes agency independence as a key prerequisite for effectiveness. We take general theoretical concepts developed primarily for industrialized contexts, and combine them with NHRI-specific literature, to develop testable hypotheses about how safeguards such as constitutional or legislative entrenchment, dismissal protections, immunity, and more could make an NHRI more effective. We then continue with conjectures that stem from more specialized literatures, to explain how investigatory functions, promotional capacities, and inclusion safeguards could also contribute to NHRI effectiveness. We focus especially on investigatory powers, including complaint-handling, as these powers continue to animate much debate within the NHRI community. Because ours is the first study to systematically assess a very broad range of NHRI safeguards around the world, we start with general theoretical claims, and see if they hold true across diverse countries, using cross-country regressions. We then turn to case studies, to explore how different formal design attributes work in different contexts.

\section{A. Independence}

28 See Daniel P. CArpenter, The Forging of Bureaucratic Autonomy (2001); Abraham L. Newman, Protectors of Privacy. Regulating Personal Data in the Global Economy (2008); Jacob E. Gersen, Overlapping and Underlapping Jurisdiction in Administrative Law, 2006 SUP. CT. REV. 201 (2007).

${ }^{29}$ Cole \& Ramirez, supra note 17 at $714-15$.

${ }^{30}$ Randeep Ramesh, Equality and Human Rights Commission Has Workforce Halved, GUARDIAN (May 15, 2012), at https://www.theguardian.com/society/2012/may/15/equality-human-rights-commission-cuts.

${ }^{31}$ Evgeny Finkel, The Authoritarian Advantage of Horizontal Accountability: Ombudsmen in Poland and Russia, 44 COMP. POL. 291, 304 (2012). 
The public administration and administrative law literature provides various reasons why, subject to qualification, one might want independent agencies. Scholars have highlighted how enacting coalitions can grant authority to independent agencies to "lock-in" politics and prevent undesirable policy drift. ${ }^{32}$ Echoing the desire to insulate agencies from unwanted interference, scholars asserts that independence can ensure more expert and impartial decision-making. ${ }^{33}$ Particular attention has been paid to protection from political capture by organized interests. ${ }^{34}$ Rachel Barkow specifies a raft of design elements that could influence capture, including an agency's funding source, personnel restrictions, the rule relationships between the agency and other agencies, and political resources. ${ }^{35}$ At the same time, however, public administration scholarship also highlights the hazards of insufficient oversight of public agencies ${ }^{36}$ and the ambiguous virtues of a bureaucracy increasingly insulated from presidential control. ${ }^{37}$

Moreover, in moving away from industrialized countries, to far more adverse political and security contexts, one could hypothesize that strong ties to the executive, and the concomitant lack of independence, might be paramount for effective NHRI operations. A number of NHRIs have been activated under autocratic conditions or in the midst of armed conflict. Under such conditions, close ties to the executive may be advantageous. As John Hatchard observed in Africa over three decades ago, "[u]nless the ombudsman is seen to have the blessing of the head of state it may well be very difficult for him to operate effectively." 38 Close ties to the executive might be especially important in the highly vertical political structures of presidential regimes in Latin America and Africa. ${ }^{39}$ Of course, an NHRI with close ties to the executive might also be fatally compromised and serve as a proxy for-rather than a check onthe government.

As the preceding discussion highlights, independence is a contentious issue informing the design of NHRIs. ${ }^{40}$ For this reason, we think it especially important to investigate this dimension empirically. According to Richard Carver, NHRI independence could be influenced by multiple factors, including "statutory basis, appointment process, criteria for membership, term of office, conflict of interest provisions, remuneration, immunities enjoyed by institution members, whether or not they can receive direct instruction from the government, and the procedure for removal of a member." 41 In our study, we have been able to collect systematic data on five of these features, which we list below. Each of these formal design safeguards, could, according to the administrative law literature, contribute to agency independence.

32 See Matthew McCubbins, Roger G. Noll \& Barry R. Weingast, Structure and Process, Politics and Policy: Administrative Arrangement and the Political Control of Agencies, 75 VA. L. REV. 431, 443 (1989).

${ }^{33}$ See generally HAGGARD \& KAUFMAN, supra note 19.

${ }^{34}$ See generally Mancur Olson, The Logic of Collective Action (1971).

35 See Rachel E. Barkow, Insulating Agencies: Avoiding Capture Through Institutional Design, 89 TEX. L. REV. 15, 42-64 (2010).

36 See Arjen Boin \& Robert E. Goodin, Institutionalizing Upstarts: The Demons of Deinstitutionalization and the Benefits of Recalcitrance, 42 ACTA POLITICA 40 (2007).

37 See David E. Lewis, The Adverse Consequences of the Politics of Agency Design for Presidential Management in the United States: The Relative Durability of Insulated Agencies, 34 BRIT. J. POL. SCI. 377 (2004).

${ }^{38}$ John Hatchard, The Institution of the Ombudsman in Africa with Special Reference to Zimbabwe, 35 INT'L \& COMP. L. Q. 255, 258 (1986).

${ }^{39}$ See Scott Mainwaring, Presidentialism in Latin America, 25 LATIN AM. RES. REV. 157 (1990).

40 See Katrien Meuwissen, NHRIs and the State: New and Independent Actors in the Multi-layered Human Rights System?, 15 HuM. RTS. L. REV. 441-84 (2015).

${ }^{41}$ Richard Carver, Measuring the Impact and Development Effectiveness of National Human Rights Institutions: A Proposed Framework for Evaluation, 22, UNDP, Bratislava Regional Ctr. (Feb. 2014) (on file with authors). 


\begin{tabular}{|c|c|}
\hline $\begin{array}{l}\text { Independence } \\
\text { Safeguards }\end{array}$ & Rationale \\
\hline $\begin{array}{l}\text { Constitutional or } \\
\text { Legislative Status }\end{array}$ & $\begin{array}{l}\text { Establishment by constitution or legislation makes NHRI charter } \\
\text { harder to amend, and NHRI more stable }\end{array}$ \\
\hline $\begin{array}{l}\text { No Dismissal Without } \\
\text { Cause }\end{array}$ & Dismissal only for good cause helps safeguard NHRI independence \\
\hline Immunity & $\begin{array}{l}\text { Immunity from prosecution helps safeguard the independence of } \\
\text { NHRI leaders }\end{array}$ \\
\hline $\begin{array}{l}\text { No Government } \\
\text { Representation }\end{array}$ & $\begin{array}{l}\text { Government representatives may compromise NHRI autonomy and } \\
\text { independence }\end{array}$ \\
\hline $\begin{array}{l}\text { Not Designated by } \\
\text { Executive }\end{array}$ & $\begin{array}{l}\text { NHRI officials appointed by the executive may have limited } \\
\text { independence. }\end{array}$ \\
\hline
\end{tabular}

\section{B. Investigatory Powers}

While the administrative law literature examines agency independence in significant depth, there is much less general theorization on investigatory powers, in part because these vary dramatically from issue area to issue area and from country to country. Nevertheless, significant variation among NHRIs on investigatory powers, and extensive practitioner debate leads us to develop theoretical conjectures about them. There are two NHRI archetypes: the ombudsman and the commission model. The ombudsman model typically involves a single appointee, empowered to investigate grievances of individual citizens against the administration. In contrast, a human rights commission is typically composed of multiple commissioners, including civil society representatives, and often conducts research on broad human rights situations and advises on legislation. Because investigatory powers, especially complaint-handling powers, are often found in NHRIs that follow the ombudsman model, but not in NHRIs that follow the commission model, they are controversial in the NHRI community.

Few design features provoke as much debate as complaint-handling powers. The UN standards on NHRI design (the "Paris Principles") leave complaint-handling as an optional feature. However, many NHRI practitioners argue that this provision should be mandatory. ${ }^{42}$ They contend that this provision directly enables an NHRI to enhance accessible and effective remedies (especially for those most vulnerable), uncover structural or systematic rights violations, and facilitate complaints by third parties on behalf of vulnerable groups. It also provides for a direct (and gratis) interface between the NHRI and the citizen, enhancing accessibility and potentially creating positive reputational feedback effects. Such an attribute is held to be particularly significant in settings where state structures are widely viewed as ineffective, dysfunctional and inaccessible. For example, the South African NHRI has linked complaint-handling to opening a door to securing redress, advancing constitutional jurisprudence, and legitimizing the amicus function of the office in ground-breaking cases,

42 Interview with Brian Burdekin, former Special Adviser on National Institutions to the UN High Commissioner for Human Rights (1995-2003) (Mar. 30, 2012). 
including the Grootboom decision by the South African Constitutional Court which ruled that the government was under an obligation to provide adequate housing. ${ }^{43}$

Nevertheless, other experts and practitioners strongly question this view. A prominent line of critique highlights the risks incumbent to complaint-handling, including capacity overload and loss of strategic focus on priority human rights issues. ${ }^{44}$ NHRIs often struggle to balance a statutory obligation to process all complaints received with a more strategic focus on the most urgent human rights issues. ${ }^{45}$ Resource concentration on complaint-handling diverts capacity away from effective monitoring of agencies and government operations that would reveal other important rights concerns. Carver concludes that "[t]he ombudsman model, driven as it is by individual complaints from members of the public, may not be the most effective way of tackling systemic human rights problems." 46 For example, most of the complaints received by the Ghanaian office concern employment disputes by public servants. ${ }^{47}$ The Ugandan NHRI has also been criticized for pursuing individual complaints to the exclusion of more urgent human rights issues afflicting the country. ${ }^{48}$

In short, because there is substantial debate on the impact of investigatory powers, and complaint-handling in particular, this question is a ripe one for empirical analysis. In the table below, we list some investigatory powers that are often found in NHRIs, as well as an enforcement prerogative that is quite rare, but characterizes some unusually powerful bodies. ${ }^{49}$ We have been able to collect data on each of these dimensions of investigatory functions.

\begin{tabular}{|l|l|}
\hline $\begin{array}{l}\text { Investigatory } \\
\text { Safeguards }\end{array}$ & Rationale \\
\hline Power to Investigate & $\begin{array}{l}\text { When NHRI can investigate on its own initiative, it can have } \\
\text { proactive role, in contrast to reactive role of judiciary }\end{array}$ \\
\hline $\begin{array}{l}\text { Can Compel Evidence } \\
\text { or Testimony }\end{array}$ & Strengthens investigation and complaint-handling powers \\
\hline Security Facilities & $\begin{array}{l}\text { The explicit power to oversee prisons allows NHRIs to monitor a } \\
\text { site of potentially grave human rights violations }\end{array}$ \\
\hline Can Refer Complaints & Facilitates access of vulnerable groups to courts \\
\hline $\begin{array}{l}\text { Individuals' } \\
\text { Complaints }\end{array}$ & $\begin{array}{l}\text { Power to hear individual complaints offers individuals direct access } \\
\text { to NHRI }\end{array}$ \\
\hline
\end{tabular}

43 The SOUTH AFrican Human Rights COMmission, CRITICALly REFLECTING ON AN INSTITUTIONAL JOURNEY 2002-2009, at 4 (2009), available at http://www.gov.za/sites/www.gov.za/files/critically_reflecting_report.pdf.

${ }^{44}$ See Carver, Measuring the Impact, supra note 41.

45 See CARVER 2005, supra note 11.

${ }^{46}$ Richard Carver, National Human Rights Institutions in Central and Eastern Europe: The Ombudsman as Agent of International Law, in HumAn Rights, StATE COMPlianCE, AND Social Change, supra note 13, at 181, 200.

${ }^{47}$ See Naefa Khan, The Commission on Human Rights and Administrative Justice in Ghana: Working in the Micro and Around the Macro, in NATIONAL HuMAN RightS INSTITUTIONS IN AFRICA. DEFENDERS OF HUMAN Rights, Managers of Conflict, Builders of Peace? 80 (Michelle Parlevliet, Guy Lamb \& Victoria Maloka eds., 2005).

${ }^{48}$ Peter Rosenblum, Tainted Origins and Uncertain Outcomes: Evaluating NHRIs, in HumAN RiGHTS, STATE COMPLIANCE, AND SOCIAL CHANGE, supra note 13, at 297, 313.

49 The most prominent example of judicial NHRIs are the Ghanaian, Kenyan, Ugandan, and Sierra Leonean offices which, to varying degrees, have court-like powers. 


\begin{tabular}{|l|l|}
\hline $\begin{array}{l}\text { Investigatory } \\
\text { Safeguards }\end{array}$ & Rationale \\
\hline Enforcement Powers & $\begin{array}{l}\text { Enforceable remedies help speed up implementation of any NHRI } \\
\text { decisions }\end{array}$ \\
\hline
\end{tabular}

\section{Promotional Functions}

As Barkow notes, "[o]ne of the most powerful weapons policy makers can give agencies is the ability to generate and disseminate information . . .." ${ }^{50}$ In the NHRI context, such powers are generally termed "promotional powers." Advocates for the commission model emphasize that NHRIs can effectively focus attention on human rights problems through their promotion work. For example, when an NHRI's mandate includes advising on legislation, the NHRI can criticize proposals with a view to securing their amendment, expansion, or withdrawal. ${ }^{51}$ Of course, the legislature would be under no obligation to defer to the NHRI's judgment. However, they may find it difficult to ignore the views of the NHRI when it is grounded in expert legal analysis and reinforced by supportive domestic and international constituencies.

Similarly, an NHRI's annual report could serve as a focal point, and shed (unwelcome) attention on a government's human rights practices. In the table below, we list three promotional safeguards commonly found in NHRIs.

\begin{tabular}{|l|l|}
\hline $\begin{array}{l}\text { Promotion } \\
\text { Safeguards }\end{array}$ & Rationale \\
\hline Advise on Legislation & $\begin{array}{l}\text { Helps make domestic legislation consistent with human rights } \\
\text { standards }\end{array}$ \\
\hline Annual Report & Helps focus public opinion on country's human rights situation \\
\hline $\begin{array}{l}\text { Education and } \\
\text { Promotion }\end{array}$ & $\begin{array}{l}\text { Promotes human rights among government agencies, educational } \\
\text { institutions, and civil society }\end{array}$ \\
\hline
\end{tabular}

\section{Inclusiveness}

Administrative law debates focus extensively on whether agencies should have broad or narrow mandates. ${ }^{52}$ NHRIs that have a broad mandate, and can receive inputs from domestic civil society and from international bodies, are sometimes considered more effective than NHRIs that have a narrower scope. For example, across a wide range of commonwealth countries, the ability of NHRIs to review claims concerning social and economic rights is widely considered a major advantage, because courts in these jurisdictions are often closed to such claims. For example, the Australian NHRIs' reports and recommendations on homeless children in 1989 and

\footnotetext{
${ }^{50}$ Barkow, supra note 35 at 59.

${ }^{51}$ Julie Mertus, Evaluating NHRIs: Considering Structure, Mandate, and Impact, in HuMAN RIGHTS, STATE COMPLIANCE, AND SOCIAL CHANGE, supra note 13, at 74, 84-86.

52 See Matthew McCubbins, Roger G. Noll \& Barry R. Weingast, Administrative Procedures as Instruments of Political Control, 3 J. L., ECON., \& ORG. 243 (1987); Tamar Gutner, Explaining the Gaps Between Mandate and Performance: Agency Theory and World Bank Environmental Reform, 5 GLoBAL ENVTL. Pol. 10 (2005); Young Han Chun \& Hal G. Rainey, Goal Ambiguity in US Federal Agencies, 15 J. PUB. AdmIN., ReS., \& THEORY 1 (2005); Geoffrey P. Miller, Independent Agencies, 1986 SuP. CT. REV. 41 (1986).
} 
the mentally ill in 1993 have been widely acknowledged as changing the protection landscape in Australia, and have been credited with changing laws, policies, programs and funding, as well as raising community awareness. ${ }^{53}$ The importance of a broad formal mandate can also be seen when political leaders restrict it. This happened in the widely criticized reform of the Mexican NHRI in 1992 when the NHRI was prohibited from intervening in electoral or labor issues. ${ }^{54}$

In addition to a broad mandate, inputs from diverse individuals and groups, both domestic and international, could help an NHRI identify and address pressing needs. Below are four relatively common NHRI institutional safeguards that provide for inclusiveness, and thus potentially affect efficacy.

\begin{tabular}{|l|l|}
\hline $\begin{array}{l}\text { Inclusiveness } \\
\text { safeguards }\end{array}$ & Rationale \\
\hline $\begin{array}{l}\text { Broad Rights } \\
\text { Mandate }\end{array}$ & $\begin{array}{l}\text { Protects human rights broadly, including social, economic, and } \\
\text { cultural rights }\end{array}$ \\
\hline $\begin{array}{l}\text { Harmonize } \\
\text { International Human } \\
\text { Rights Law }\end{array}$ & $\begin{array}{l}\text { Allows NHRI to help harmonize domestic law with international } \\
\text { human rights standards }\end{array}$ \\
\hline \begin{tabular}{l} 
Engage $\begin{array}{l}\text { International } \\
\text { Organizations }\end{array}$ \\
\hline $\begin{array}{l}\text { Civil Sith } \\
\text { Representation }\end{array}$
\end{tabular} & $\begin{array}{l}\text { Helps connect NHRI to international organizations } \\
\text { groups. }\end{array}$ \\
\hline
\end{tabular}

While NHRIs have not been extensively studied, literatures on courts, legislatures, constitutions, and other institutions suggest that formal safeguards matter more in democratic regimes. ${ }^{55}$ In democratic states, the public can hold their elected leaders to account for human rights abuses and thus the political elite have a greater incentive to support, rather than undermine, the NHRI's effectiveness. Furthermore, autocratic regimes may be able to mitigate the domestic and international repercussions of human rights violations by suppressing incriminating information. In contrast, the civil liberties upheld by democratic states make it much more difficult for democratic leaders to mitigate the political fallout from human rights violations committed by state agents. By studying democracies and authoritarian regimes separately, we are able to assess whether institutional safeguards matter more under democratic or authoritarian conditions. In so doing, we build on Beth Simmons's work, which emphasizes

${ }^{53}$ See Australian Human Rights Commission, Report of the National Inquiry into Youth Homelessness (Feb. 10, 1989); Australian Human Rights Commission, Report of the National Inquiry into the Human Rights of People with Mental Illness (Oct. 20, 1993); Chris Sidoti, Australian Human Rights Commissioner, Address at the National Conference on Mental Health Services, Policy and Law Reform into the Twenty First Century: Mental Health for All: What's the Vision? (Feb. 13-14,1997), available at https://www.humanrights.gov.au/news/speeches/mentalhealth-all-whats-vision.

54 JoHn ACKERMAN, ORganismos AutÓnOmos y DemOCRACIA: El CASO MEXICANO 130 (2007).

55 See Rule by Law: The Politics of Courts in Authoritarian Regimes (Tom Ginsburg \& Tamir Moustafa eds., 2008); Peter Solomon, Courts and Judges in Authoritarian Regimes, 60 World POL. 122 (2007); Beatriz Magaloni \& Ruth Kricheli, Political Order and One-Party Rule, 13 ANN. REV. POL. ScI. 123 (2010); Tom Ginsburg \& Mila Versteeg, Why Do Countries Adopt Constitutional Review?, 30 J. L. ECON. \& ORG. 587 (2014). 
that human rights treaties are likely to have different effects depending on a country's democracy level. ${ }^{56}$

Why might formal institutional design matter, even when an agency is intended to constrain an authoritarian leader in a country with mixed respect for the rule of law? Formal institutional design can help guide the agency itself - its ambition, the areas which it might prioritize, and fields from which it might steer clear. For example, if an NHRI is explicitly given diverse promotional powers, its head might decide to hire public relations personnel, whereas if an NHRI is explicitly given diverse investigatory powers, its head might instead decide to hire lawyers. Formal institutional design is also likely to shape resistance to the NHRIs activity. If an NHRI head embarrasses the executive, but is constitutionally entrenched, given a long mandate, immunity, and other independence safeguards, this person may stay in office for longer than an NHRI head that lacks these safeguards. Similarly, if NHRI activity clearly falls within its formal mandate, litigation challenging this activity might never be initiated, or might fail. In the longer term, an NHRI that is empowered and makes use of its broad mandate in opportune moments might build up allies, who in turn can help it to resist pressure in hard times. In a similar vein, Barkow argues that policy diversification can increase an agency's resistance to capture. ${ }^{57} \mathrm{In}$ contrast, an NHRI with a narrow mandate might not get the chance to build a track record of effective contributions, and might become more vulnerable to criticism that its budget should be cut or that an alternative institution should be built in its place.

\section{ASSESSING NHRI EFFECTIVENESS: QUANTITATIVE ANALYSES}

To investigate whether NHRI institutional design matters, we combine qualitative and quantitative methods, and pay attention to alternative explanations and to diverse sources of bias. We flag some lessons on combining qualitative and quantitative methods to study international law problems and elaborate more fully on these techniques in other writing. ${ }^{58}$

This section begins by discussing our two quantitative measures of NHRI effectiveness: grades awarded by an NHRI peer review network, and an original expert survey. We then elaborate on our dataset we constructed. While previous scholarship only examines whether a country has or has not adopted an NHRI, ${ }^{59}$ we identified twenty-two distinct institutional features of NHRIs, based on extensive scholarly and practitioner consultation, and compiled an original dataset of these features in 107 NHRIs. ${ }^{60}$ We then present our findings, which assess quantitatively whether particular institutional design features are linked to greater effectiveness. We find tentative support for the hypothesis that more institutional safeguards lead to more effective institutions. We find strong support for the hypothesis that investigatory features in particular contribute to NHRI effectiveness. We also find strong support for the hypothesis that formal institutional safeguards are especially likely to contribute to organizational effectiveness in democratic settings (although we also observe some effects across transition and authoritarian

${ }^{56}$ See Simmons, supra note 2.

57 Barkow, supra note 35 , at 50.

${ }^{58}$ See Katerina Linos, How to Select and Develop International Law Case Studies: Lessons from Comparative Law and Comparative Politics, 109 AJIL 475 (2015); Katerina Linos \& Melissa Carlson, Qualitative Methods for Law Review Writing, 84 U. CHI. L. REV. 213 (2017).

${ }^{59}$ See Kim, supra note 23; Cole \& Ramirez, supra note 17.

${ }^{60}$ For details on the dataset and data collection process see Linos \& Pegram, The Language of Compromise, supra note 7. We are immensely grateful to Ryan Goodman and Derek Jinks for their invaluable assistance in this data collection effort. 
regimes). We present additional details, as well as robustness checks, for our quantitative analyses, in an online appendix.

\section{A. Measuring NHRI Effectiveness}

To assess NHRI effectiveness, we turn to two measures specific to NHRIs, NHRI grades and expert survey scores, rather than studying a country's overall human rights situation before and after the NHRI was adopted. In selecting agency-specific, rather than country-level assessments, we follow best practice in the comparative study of other types of administrative agencies. ${ }^{61} \mathrm{NHRI}$-specific measures are preferable to more general country-wide human rights scores, because many bodies and individuals - including the executive, the legislature, and the judiciary - contribute to a country's overall human rights situation. Therefore, improvements correlated with the adoption of an NHRI might be due to other factors. For example, when a new reform-minded president is elected, he might set up an NHRI and also change police leadership. A country's police practices could improve shortly after the NHRI is established, even if this NHRI does nothing at all, because the reform-minded president has also improved other institutions. In more technical terms, NHRI-specific ratings are less likely to capture noise, and, in addition, are less likely to give rise to endogeneity concerns.

At the same time, both of our measures have important limitations, which we detail below. The biggest problem with using NHRI grades as measures of NHRI effectiveness is that grading is based in part on formal compliance with the Paris Principles. Thus, if our quantitative results suggested that features emphasized in the Paris Principles contributed to greater NHRI effectiveness, we would not be able to tell whether this was an artifact of the grading process. As our main quantitative finding is that certain investigatory features-notably individual complaint-handling - contribute to NHRI effectiveness, and these investigatory features are not emphasized in the Paris Principles, we are less concerned about this bias. The biggest limitation with using expert survey scores as a measure of NHRI effectiveness is that experts assess the reputation, rather than the actual performance, of an NHRI; these are often, but not always, correlated. We address this limitation in part by combining expert survey scores (which are based on a quick overall assessment of an institution) with NHRI grades (which are based on very detailed formal assessments of NHRI performance). We also address this limitation by turning, in the next section, to carefully selected qualitative studies of specific NHRIs, an approach that allows us to study multiple dimensions of NHRI performance, such as success in attracting individual complaints, success in resolving individual complaints, success in attracting media attention to particular human rights issues, and success in changing legislation. While none of the measures we use are perfect, by triangulating across measurements and sources, and by building significantly more nuanced measures of effectiveness than are typically used in comparative studies, we make significant progress in the assessment of NHRI effectiveness.

\section{NHRI peer review grades}

Our first measure to assess NHRI effectiveness is the average grade an NHRI has received by their NHRI peer review network. Since 1999, an independent, but UN-affiliated, NHRI peer review network, the Global Alliance of National Human Rights Institutions (GANHRI) (formerly the International Coordinating Committee of NHRIs), and specifically its

\footnotetext{
${ }^{61}$ Hanretty \& Koop, supra note 24, at 7-10.
} 
Sub-committee on Accreditation (SCA), has given letter grades to individual NHRIs indicating compliance with the Paris Principles. ${ }^{62}$ The SCA is unique within UN structures, serving as the gatekeeper of these international standards, independent of UN member states. Significantly, "A" status NHRIs are granted participation rights in the UN Human Rights Council. ${ }^{63}$ The UN Office of the High Commissioner for Human Rights (OHCHR) serves as a permanent observer and secretariat to the SCA and the Sub-Committee invites information from third parties to inform its work. We have collected historical grading data from GANHRI reports, with countries given a score of four for an A (full compliance), three for an A(reserved), two for a B (partial compliance), one for a C (non-compliance), and zero if the NHRI was suspended or accreditation was revoked. ${ }^{64}$

Preliminary research shows that this peer-grading system, promoted by the UN, has had significant policy effects, leveraging both Paris Principles compliance and - most significantlyenhanced NHRI performance. ${ }^{65}$ Information on SCA composition, methods of assessment, and criteria for grading can be found in its Rules of Procedure. ${ }^{66}$ In recent years, the SCA has sought to fill important gaps in the interpretation of the Paris Principles, ${ }^{67}$ as well as enhance transparency of its grading decisions. ${ }^{68}$ According to the SCA, NHRI grades reflect an applicant's compliance with the Paris Principles "in both law and practice," including whether "an applicant's actions demonstrate that it is effectively fulfilling its mandate to promote and protect human rights." ${ }^{\prime} 9$ To this end, the Sub-Committee has recently issued guidance on assessing the performance of NHRIs and is investigating further instruments for evaluating actual performance in order to strengthen the accreditation mechanism. ${ }^{70}$

SCA assessment therefore focuses on both technical compliance and actual NHRI performance. Observers disagree on whether accreditation is sufficiently strict. ${ }^{71}$ As of May 2017, 78 of 121 accredited NHRIs, or 64 percent, are classified as "A" status. ${ }^{72}$ Although this represents a decline from 74 percent of the total population in $2004,{ }^{73}$ the SCA continues to

\footnotetext{
${ }^{62}$ See GANHRI, supra note 8.

${ }^{63}$ See Linos \& Pegram, Architects of Their Own Making, supra note 8 (for analysis of significance of the GANHRI and Sub-committee on Accreditation (SCA) for Paris Principles compliance).

64 "A(reserved)" was retired in 2010 and "C" status in 2017.

${ }^{65} \mathrm{We}$ are developing a project investigating the significance and impact of the SCA, emblematic of peer review and global performance assessments as important new tools in global governance. See Judith G. Kelley \& Beth A. Simmons, Politics by Number: Indicators as Social Pressure in International Relations, 59 AM. J. POL. SCI. 55 (2015).

${ }^{66}$ GANHRI Rules of Procedure for the GANHRI Sub-Committee on Accreditation, adopted 6 March 2017, at http://nhri.ohchr.org/EN/AboutUs/GANHRIAccreditation/Pages/SCAGeneralObservations.aspx.

67 GANHRI General Observations of the Sub-Committee on Accreditation, adopted 6 March 2017, at http://nhri.ohchr.org/EN/AboutUs/GANHRIAccreditation/Pages/SCAGeneralObservations.aspx.

${ }^{68}$ GANHRI Rules of Procedure, supra note 66.

${ }^{69} I d$., Rule 8.1.

70 See GANHRI Bureau, Practice Note 3: Assessing the Performance of NHRIs, 6 March 2017, at http://nhri.ohchr.org/EN/AboutUs/GANHRIAccreditation/Pages/SCAGeneralObservations.aspx.

${ }^{71}$ See Meg Brodie, Progressing Norm Socialisation: Why Membership Matters. The Impact of the Accreditation Process of the International Coordinating Committee of National Institutions for the Promotion and Protection of Human Rights, 80 NoRdic J. INT'L L. 143, 160 (2011); Peter Rosenblum, Tainted Origins and Uncertain Outcomes, in Human Rights, StATE COMPLiAnCE, AND SOCIAL CHANGE, supra note 13, 297.

72 Data from Reports of the SCA, available at http://nhri.ohchr.org/EN/Documents/Status\%20Accreditation\%20Chart\%20.pdf (includes all accredited and reaccredited NHRIs).

${ }^{73}$ See Linos \& Pegram, Architects of Their Own Making, supra note 8, 1124.
} 
generally rule an NHRI to be "full compliance." Grounds for grading and downgrading have increasingly focused upon performance rather than design. ${ }^{74}$ While some NHRIs may not technically comply with the Paris Principles, widely documented effective performance appear to override such concerns. ${ }^{75}$ However, in other instances, external observers do raise concerns over "A" status designation of poor-performing NHRIs. ${ }^{76}$ Growing reliance by the SCA on accreditation deferrals is indicative of difficulties, ${ }^{77}$ including resistance by NHRIs themselves to more stringent review, especially where government obstruction is at fault. A recent rash of challenges to SCA decisions by NHRIs threatened with downgrading speaks to the fraught internal politics associated with efforts to "give teeth" to this peer review mechanism. ${ }^{78}$

As the above indicates, NHRI grades are imperfect measures of efficacy and it is important to acknowledge potential biases in the grading process. Effectiveness should be measured not by adherence to a script of globally preferred design features, but on assessment of the extent to which an NHRI has improved human rights protections. Grading based on formal compliance does risk bias. Specifically, the grading process places special weight on the Paris Principles, which emphasize promotional NHRI features and deprioritize investigatory features. ${ }^{79}$ If we observed a strong correlation between promotional features and high grades, we would not be able to tell whether this was an artifact of the grading process. As it turns out, we observe that NHRIs with investigatory features tend to receive higher grades. As these are not emphasized in the grading process, we are less concerned about possible bias.

Another concern stems from the political nature of SCA decision-making. Historical grading patterns do indicate some grade inflation, with "A" status spanning very effective, moderately effective, and even potentially non-effective NHRIs. However, while individual SCA assessments will not be entirely free of noise, this should not lead us to find insignificant effects in our regression analysis when there are true significant effects. Too much noise in the grading process could prevent us from identifying effects that actually exist. While "A" status designation includes both highly effective and modestly effective NHRIs, we are relatively confident that designations below "A" status indicate problems in NHRI effectiveness; this demarcation between " $A$ " and below "A" allows us to distinguish somewhat effective from somewhat problematic NHRIs. At the same time, because the grading process is noisy, the quantitative analysis groups together NHRIs from around the world, and the grading process summarizes a lot of information in a single score, we supplement our quantitative analysis with careful qualitative work, to study whether particular safeguards might have particular effects in specific contexts.

\footnotetext{
74 See cases of downgrading in Honduras (2010), Sri Lanka (2007), Thailand (2014), and Venezuela (2015).

${ }^{75}$ See, e.g., Palestine Review, in GANHRI Report and Recommendations of the Session of the Sub-Committee on Accreditation, at 34 (Nov. 2015) ("PICHR continues to be an effective" NHRI, despite concerns expressed over lack of primary legislation); see also Australia Review, in GANHRI Report and Recommendations of the Session of the Sub-Committee on Accreditation, at 10-13 (Nov. 2016) (concerns expressed over selection and appointment).

${ }^{76}$ Qatar: National Human Rights Committee to Keep Status A Despite Lack of Independence from the Executive, AlKARAMA (Feb. 1, 2016), at https:/www.alkarama.org/en/articles/qatar-national-human-rightscommittee-keep-status-despite-lack-independence-executive. See also AiNNI, An NGO Report on the Compliance with the Paris Principles by the National Human Rights Commission of India (Jan. 22, 2011), available at http://www.peopleswatch.org/dm-documents/HRD/NGO\%20Report_Paris\%20Principles_NHRC_India.pdf.

77 UN Body Defers NHRC Accreditation, INDIAN EXPRESS (Feb. 12, 2017), at http://indianexpress.com/article/india/un-body-defers-nhrc-accreditation-4520132.

78 See Preface Note in GANHRI Report and Recommendations of the Session of the Sub-Committee on Accreditation (May 9-13, 2016; Mar. 13-17, 2017).

${ }^{79}$ Linos \& Pegram, The Language of Compromise, supra note 7, at 615-16.
} 


\section{Expert survey scores}

Second, we combine the above measure with an expert survey - a tool that prior work on political parties suggests can be particularly valid for cross-country comparisons. ${ }^{80}$ Sixty experts with in-depth knowledge of NHRI activities and impact on human rights protection within their own country, region, and beyond, including policy makers, human rights practitioners, civil society representatives, and former NHRI officials, were identified by the project principals. Experts were asked to rank the effectiveness of individual NHRIs on a five-point scale. More specifically, experts were asked to what extent an NHRI "positively improved and alleviated the human rights situation of individuals and groups in a given society," broadly following the general definition of effectiveness offered by the UN Office of the High Commissioner for Human Rights. ${ }^{81}$ Experts were instructed to evaluate only those NHRIs with which they were familiar.

The survey was piloted among two experienced NHRI practitioners prior to general circulation, with their feedback incorporated into the final document. An expert survey targeted at individuals with access to multiple sources of information is particularly appropriate to this study given the complexity of assessing NHRI effectiveness in diverse contexts. It was also important to ensure a cross section of regional expert representation to reduce referent group bias. Thirty-six of the sixty experts we contacted (60 percent), drawn from five continents (Africa, the Americas Asia-Pacific, Europe, and the Middle East and North Africa), completed the survey. This survey represents our original data collection effort, which we administered in 2013.

Expert surveys are not yet widely used by legal academics, but are particularly promising tools as legal scholars are well-positioned to draft appropriate questions about agency design and are often well-connected within expert communities, thus can expect to get a high response rate. Nevertheless, expert surveys are also not immune from bias. As with NHRI grades, there is a risk that expert judgment will be influenced by the dominant formal model. This form of bias could lead experts to inflate their ratings for Paris Principles-compliant NHRIs displaying the full suite of strongly recommended promotional features. However, this is not what we find, with our expert ratings correlating with a different set of NHRI structural profiles. As such, we are less worried about this form of bias. Another concern with expert surveys is that they may measure perceptions of efficacy, rather than actual efficacy. Notwithstanding, we follow studies of other types of administrative agencies, such as antitrust authorities, in suggesting that expert ratings are one of the best available ways to assess agency effectiveness. ${ }^{82}$ Experts were also carefully selected to ensure familiarity with the actual practice of these organizations.

There is no perfect measure of NHRI effectiveness, nor is a single indicator which can fully encapsulate it likely to emerge. Combining these measures with detailed case studies helps counteract, but cannot eliminate, the concerns identified. We hope that this research effort will encourage scholars to further advance the state-of-the-art on organizational effectiveness.

\footnotetext{
${ }^{80}$ See Online Appendix 1 in AJIL Unbound.

${ }^{81}$ See Office of the High Commissioner for Human Rights (OHCHR), The 20th Anniversary of OHCHR: 20 Human Rights Achievements,

http://www.ohchr.org/EN/NewsEvents/OHCHR20_Backup/Pages/Achievements.aspx.

${ }^{82}$ Hanretty \& Koop, supra note 24, at 7-10.
} 


\section{Controlling for alternative explanations}

NHRI institutional design is quite stable over time. Stability in NHRI safeguards is important theoretically, as it suggests that governments hostile to NHRIs cannot significantly overhaul their institutional structure in times of crisis. Empirically, this requires us to present cross-sectional models, where we compare one country to other countries (rather than comparing one country to itself in different moments in time). Cross-sectional models require carefully specified controls, so we run multiple model specifications, to ensure that the inclusion (or exclusion) of certain control variables are not driving our results. There are occasional changes in NHRI safeguards over time. As these are rare, we examine them through qualitative case studies.

We utilize a variety of control variables, including a country's political system, human rights performance and level of wealth, as it is possible that it is easier for NHRIs to perform effectively in rich, democratic states that experience lower levels of human rights abuse. It is also possible that external pressure influences NHRI performance; therefore, we control for how much a country is criticized for its human rights performance, and how many INGOs it hosts. Finally, we include a binary variable, coding whether or not the NHRI was established before or after the UN promulgated the Paris Principles on NHRIs.

These control variables are based on the human rights literature generally, and on the literature on NHRIs in particular. ${ }^{83}$ Controls are listed in Table 1. In online appendix 1, we investigate alternative specifications, with more and fewer control variables; results are quite consistent across specifications. Additional control variables that we investigate (in online appendix 1) include the population of the country, whether the state experienced a civil war within ten years of the establishment of an NHRI, and how open a country is to international trade (see online appendix 1, Tables A9 and A10). We also run models with fewer control variables, in order to retain more countries in the models, and again results do not change (see online appendix 1, Tables A11 and A12).

TABLE 1

CONTROL VARIABLES

\section{Control Variables in Main Specifications}

Democracy Score - A score that indicates how democratic or authoritarian a state is in the year prior to establishing an NHRI (based on polity data). ${ }^{84}$

Human Rights Score - A score that indicates the state's protection of human rights in the year prior to establishing an NHRI (based on physical integrity scores). ${ }^{85}$

Logged GDP per Capita - The log of a country's GDP per capita in the year prior to the establishment of the country's NHRI ${ }^{86}$

83 See Kim, supra note 23; Emilie HafNer-Burton, MAKIng Human Rights A Reality (2013); Emilie Hafner-Burton, Trading Human Rights: How Preferential Trade Agreements Influence Government Repression, 59 INT'L ORG. 593 (2005); Linos \& Pegram, The Language of Compromise, supra note 7.

${ }^{84}$ Monty G. Marshall \& Keith Jaggers, Polity IV Project: Political Regime Characteristics AND TRANSITIONS, 1800-2002, DATASET USERS' MANUAL (2002), available at http://www3.nd.edu/ mcoppedg/crd/PolityIVUsersManualv2002.pdf. (2004).

${ }^{85}$ See David L. Cingranelli, The Cingranelli-Richards (CIRI) Human Rights Data Project, 32 HuM. RTS. Q. 395 
Naming and Shaming - An index that reflects the attention a country receives for human rights abuses, from general media (e.g., Newsweek), advocacy groups (e.g., Amnesty International), and the United Nations Commission on Human Rights in the year prior to the establishment of an NHRI. ${ }^{87}$

INGO Score - Active INGOs often correlate with better human rights practices. Total number of INGOs that count at least one citizen or domestic organization as a member, from the Union of International Associations. Score reflects the number prior to NHRI establishment. $^{88}$

NHRI After 1992 - A binary variable that takes the value of one if the NHRI was established after the United Nations' adoption of the Paris Principles, which outlined recommendations for NHRIs.

\section{Additional Control Variables in Alternative Specifications}

Population - The size of the country's population in the year prior to the NHRI's enactment. $^{89}$

Civil War - A binary variable that takes the value of one if the state if the country experienced a civil conflict within ten years of an NHRI's enactment. ${ }^{90}$

Trade as a Percent of GDP - Countries that are more economically dependent on other states may be more susceptible to international human rights pressure. This variable records trade as a percentage of a country's GDP in the year prior to the establishment of its NHRI. ${ }^{91}$

\section{B. Quantitative Findings on NHRI Effectiveness}

Our first hypothesis is that NHRIs with more institutional safeguards of any type are more likely to obtain high grades and high expert survey scores. Our first independent variable is a simple count of formal institutional safeguards; it could theoretically range from zero to twenty-two, but in our dataset it ranges from six to nineteen. We find a positive and statistically significant correlation between the number of safeguards an NHRI has, and higher NHRI grades, even when including controls. In contrast, when we include control variables, we do not find a

${ }^{86}$ The World Bank, World Bank National Accounts Data and OECD National Accounts Data Files: GDP Per Capita (1960-2015), at http://data.worldbank.org/indicator/NY.GDP.PCAP.CD.

87 See Wade M. Cole \& Francisco O. Ramirez, Conditional Decoupling Assessing the Impact of National Human Rights Institutions, 1981 to 2004, 78 AM. SOC. REV. 702 (2013).

${ }^{88} \mathrm{Id}$.

${ }^{89}$ See Kristian S. Gleditsch, Expanded Trade and GDP Data, 46 J. ConfliCT RESOL. 712 (2002).

90 See Nils Petter Gleditsch, Peter Wallensteen, Mikael Eriksson, Margareta Sollenberg \& Håvard Strand, Armed Conflict 1946-2001: A New Dataset, 39 J. PEACE RES. 615 (2002); Therése Pettersson \& Peter Wallensteen, Armed Conflicts, 1946-2014, 52 J. PEACE RES. 536 (2015).

${ }^{91}$ The World Bank, World Bank National Accounts Data and OECD National Accounts Data Files: Trade (\% of GDP) (1960-2015), at http://data.worldbank.org/indicator/NE.TRD.GNFS.ZS. 
statistically significant correlation between more NHRI safeguards and higher NHRI survey scores (see Table 2).

The regressions in Table 2 demonstrate that NHRIs with more institutional safeguards tend to receive higher marks from the GANHRI. We also investigate whether NHRIs function differently in democracies and in authoritarian regimes. To separate our sample into democracies, on the one hand, and transition and authoritarian regimes on the other, we identify states with a polity score of one or higher as democracies. ${ }^{92}$ We find that the correlation between more institutional safeguards (of any type), and NHRI effectiveness is much stronger for democracies than for authoritarian and transition regimes. All our regression models are based on Ordinary Least Squared regression (OLS). Therefore, results are easy to interpret, as each variable's coefficient indicates the expected effect a one-unit change in the independent variable has on the dependent variable. For example, a democratic state's average grade over time, on a four-point scale, is expected to be .12 points higher for each additional safeguard that the NHRI incorporates (as compared to 0.06 points for other states). Another way to interpret this coefficient is to compare countries with many NHRIs safeguards (in the top 10 percent) to countries with few NHRI safeguards (in the bottom 90 percent). Among democracies, we expect countries in the top 90 percent of formal NHRI safeguards to be a full grade higher on average than states in the bottom 10 percent.

TABLE 2

NHRIs With More SAFEguards Get Higher Average Grades

\begin{tabular}{lcccccc}
\hline & \multicolumn{3}{l}{$\begin{array}{l}\text { Dependent Variable: } \\
\text { NHRI Grade }\end{array}$} & \multicolumn{5}{c}{$\begin{array}{c}\text { Dependent Variable: } \\
\text { Expert Survey Score }\end{array}$} \\
\hline & $(1)$ & $(2)$ & $(3)$ & $(4)$ & $(5)$ & $(6)$ \\
\hline & All & Dem & Auth & All & Dem & Auth \\
\hline \multirow{3}{*}{ Total No. of Safeguards } & $0.06^{*}$ & $0.12^{* * *}$ & 0.01 & 0.03 & 0.02 & 0.03 \\
& $(0.03)$ & $(0.04)$ & $(0.05)$ & $(0.03)$ & $(0.05)$ & $(0.06)$ \\
Democracy Score & 0.01 & 0.01 & -0.04 & $0.04^{*}$ & $0.17^{* *}$ & 0.00 \\
& $(0.02)$ & $(0.07)$ & $(0.08)$ & $(0.02)$ & $(0.07)$ & $(0.09)$ \\
Human Rights Score & -0.04 & 0.06 & -0.12 & 0.05 & 0.06 & -0.02 \\
Logged GDP per Capita & $(0.06)$ & $(0.07)$ & $(0.10)$ & $(0.06)$ & $(0.07)$ & $(0.12)$ \\
& -0.02 & -0.16 & 0.14 & -0.13 & -0.01 & -0.24 \\
Naming and Shaming & $(0.11)$ & $(0.16)$ & $(0.18)$ & $(0.11)$ & $(0.16)$ & $(0.21)$ \\
& 0.08 & 0.15 & 0.04 & 0.08 & $0.24 *$ & 0.03 \\
INGOs Score & $(0.06)$ & $(0.12)$ & $(0.08)$ & $(0.06)$ & $(0.12)$ & $(0.10)$ \\
& 0.26 & 0.41 & $0.65^{*}$ & $0.38^{*}$ & -0.02 & 0.53 \\
NHRI After 1992 & $(0.22)$ & $(0.31)$ & $(0.36)$ & $(0.22)$ & $(0.32)$ & $(0.41)$ \\
& -0.26 & -0.30 & 0.00 & $-0.40^{*}$ & -0.38 & -0.28 \\
Constant & $(0.22)$ & $(0.25)$ & $(0.42)$ & $(0.22)$ & $(0.25)$ & $(0.48)$ \\
& 1.50 & 0.25 & -1.55 & 1.05 & 1.89 & 0.87
\end{tabular}

\footnotetext{
${ }^{92}$ Models presented in the appendix demonstrate that the results are robust to changes in the cut-point between democracies and autocracies. More specifically, when we compare stable democracies (scoring over five on the polity score) to all other countries, we find similar patterns.
} 


\begin{tabular}{lllllll} 
Observations & 65 & 41 & 24 & 62 & 39 & 23 \\
R-squared & 0.19 & 0.30 & 0.40 & 0.27 & 0.31 & 0.29 \\
\hline Standard & & & & & &
\end{tabular}

Standard errors in

parentheses

$* * * \mathrm{p}<0.01, * * \mathrm{p}<0.05, * \mathrm{p}<0.1$

We next turn to investigate which NHRI safeguards contribute most to higher effectiveness scores. Our cumulative index (where we simply add up the total number of safeguards) could conceal as much as it reveals, if some safeguards are very important even in authoritarian regimes, while others are useless. As described in Part I above, we have constructed four indexes, based on administrative law theory and on NHRI-specific writings; additional details are available in the online appendix.

Our main finding is that investigatory powers are particularly likely to contribute to NHRI effectiveness. Table 3 suggests that NHRIs that have more formal safeguards related to investigating human rights appear to be especially effective relative to other NHRIs. More specifically, NHRIs that have more investigative safeguards are more likely to receive higher grades and higher expert survey scores than NHRIs lacking these safeguards.

We also find that investigatory powers are important across NHRIs, but particularly likely to contribute to NHRI effectiveness in democratic states. In a democratic country, an NHRI with an additional investigative safeguard is likely to receive a .25 point increase in the GANHRI's average grade (on a four-point scale). An NHRI in a democratic country with an additional investigative safeguard is also likely to receive a .22 point increase in its average expert survey score (five-point scale). The relationship between more safeguards related to investigations, and higher NHRI grades and scores is very robust, and holds across different country types, with different types of controls included and excluded, whether or not we include outlier NHRIs. We conduct a large variety of robustness checks in the online appendix, and these results hold up.

In contrast, the relationships between the other indexes we study and more effective NHRIs are not robust to alternative specifications. It is very possible that NHRIs with greater formal independence and NHRIs with a more inclusive mandate are more effective in particular types of contexts, as Table 3 suggests, but the correlations we see are too tentative to make firm generalizations.

TABLE 3

NHRIs With More InVEstigative SAFEguards Get Higher AVERAge Grades AND ExPERT SURVEY SCORES

\begin{tabular}{|c|c|c|c|c|c|c|}
\hline & \multicolumn{3}{|c|}{$\begin{array}{l}\text { Dependent Variable: } \\
\text { NHRI Grade }\end{array}$} & \multicolumn{3}{|c|}{$\begin{array}{l}\text { Dependent Variable: } \\
\text { Expert Survey Score }\end{array}$} \\
\hline & (1) & $(2)$ & (3) & (4) & $(5)$ & (6) \\
\hline & All & Dem & Auth & All & Dem & Auth \\
\hline Investigate Index & $\begin{array}{r}0.14^{*} \\
(0.07)\end{array}$ & $\begin{array}{l}0.25^{* *} \\
(0.10)\end{array}$ & $\begin{array}{c}0.10 \\
(0.11)\end{array}$ & $\begin{array}{l}0.16^{* *} \\
(0.07)\end{array}$ & $\begin{array}{l}0.22 * * \\
(0.11)\end{array}$ & $\begin{array}{c}0.14 \\
(0.10)\end{array}$ \\
\hline
\end{tabular}




\begin{tabular}{|c|c|c|c|c|c|c|}
\hline Independence Index & $\begin{array}{c}0.04 \\
(0.08)\end{array}$ & $\begin{array}{c}0.16 \\
(0.10)\end{array}$ & $\begin{array}{c}0.03 \\
(0.18)\end{array}$ & $\begin{array}{c}0.01 \\
(0.08)\end{array}$ & $\begin{array}{l}-0.03 \\
(0.10)\end{array}$ & $\begin{array}{c}0.29^{*} \\
(0.16)\end{array}$ \\
\hline \multirow[t]{2}{*}{ Promotion Index } & 0.08 & 0.09 & -0.24 & -0.17 & -0.08 & $-0.89 * * *$ \\
\hline & $(0.14)$ & $(0.18)$ & $(0.32)$ & $(0.14)$ & $(0.16)$ & $(0.28)$ \\
\hline \multirow[t]{2}{*}{ Inclusiveness Index } & 0.15 & $0.33 * *$ & -0.24 & -0.07 & -0.16 & -0.19 \\
\hline & $(0.11)$ & $(0.12)$ & $(0.28)$ & $(0.11)$ & $(0.12)$ & $(0.24)$ \\
\hline \multirow[t]{2}{*}{ Democracy Score } & 0.01 & -0.04 & 0.00 & $0.05^{* *}$ & $0.22 * * *$ & 0.11 \\
\hline & $(0.03)$ & $(0.07)$ & $(0.09)$ & $(0.03)$ & $(0.07)$ & $(0.07)$ \\
\hline \multirow[t]{2}{*}{ Human Rights Score } & -0.03 & 0.06 & -0.14 & 0.03 & 0.05 & -0.09 \\
\hline & $(0.06)$ & $(0.07)$ & $(0.10)$ & $(0.06)$ & $(0.07)$ & $(0.09)$ \\
\hline \multirow[t]{2}{*}{ Logged GDP per Capita } & 0.07 & 0.05 & 0.06 & $0.11 *$ & $0.24 * *$ & 0.08 \\
\hline & $(0.06)$ & $(0.13)$ & $(0.09)$ & $(0.06)$ & $(0.12)$ & $(0.08)$ \\
\hline \multirow[t]{2}{*}{ Naming and Shaming } & -0.24 & -0.31 & 0.31 & $-0.37^{*}$ & $-0.53 * *$ & 0.52 \\
\hline & $(0.22)$ & $(0.26)$ & $(0.51)$ & $(0.22)$ & $(0.23)$ & $(0.43)$ \\
\hline \multirow[t]{2}{*}{ INGOs Score } & 0.26 & 0.44 & 0.68 & 0.30 & -0.14 & $0.76^{* *}$ \\
\hline & $(0.22)$ & $(0.31)$ & $(0.40)$ & $(0.21)$ & $(0.29)$ & $(0.34)$ \\
\hline \multirow[t]{2}{*}{ NHRI After 1992} & 0.00 & -0.10 & 0.26 & -0.03 & 0.12 & 0.11 \\
\hline & $(0.12)$ & $(0.17)$ & $(0.20)$ & $(0.11)$ & $(0.15)$ & $(0.18)$ \\
\hline \multirow[t]{3}{*}{ Constant } & 0.87 & -0.91 & -1.53 & 1.17 & 1.66 & -1.28 \\
\hline & $(1.43)$ & $(1.81)$ & $(3.26)$ & $(1.44)$ & $(1.86)$ & $(2.77)$ \\
\hline & $0.14^{*}$ & $0.25 * *$ & 0.10 & $0.16 * *$ & $0.22 * *$ & 0.14 \\
\hline Observations & 65 & 41 & 24 & 62 & 39 & 23 \\
\hline R-squared & 0.23 & 0.40 & 0.51 & 0.37 & 0.50 & 0.68 \\
\hline
\end{tabular}

Standard errors in

parentheses

$* * * \mathrm{p}<0.01, * * \mathrm{p}<0.05, * \mathrm{p}<0.1$

Even though the relationship between more investigatory safeguards and higher NHRI grades and survey scores is very robust, the statistical analyses we have presented can only demonstrate correlations. We next explore qualitative evidence to identify the causal mechanisms at work.

\section{ASSESSING NHRI EFFECTIVENESS: CASE STUDIES}

In this section, we develop paired case studies from Asia Pacific and South America to deepen exploration of how the presence (or absence) of protective and promotional design features contribute to NHRI effectiveness. Case studies allow us to go beyond the correlations just described, which link the presence of design attributes to effectiveness assessments. Case studies illuminate whether and how these safeguards are employed in different contexts, and allow us to better understand why particular safeguards could lead to more effective NHRIs. We establish the plausibility of effectiveness claims through two techniques: careful within-region case selection and extensive within-case process tracing. ${ }^{93}$ This involves investigating a series of logically interconnected propositions about how formal safeguards are used in different contexts,

${ }^{3}$ See Linos, How to Select and Develop International Law Case Studies, supra note 58; Linos \& Carlson, supra note 58; GEORGE \& BENNETT, supra note 26. 
how governmental actors respond, what substitutes are invented, with a view to causally linking particular outcomes to particular safeguards, and not to background conditions.

How might institutional design attributes improve human rights outcomes? If an NHRI is given a mandate to receive complaints or advise on legislation, does it carry out such actions frequently and effectively, or does its mandate go unutilized? Do NHRI activities provoke governmental responses, and if so, is there mostly governmental backlash, or also a positive response? Do human rights observers praise or criticize the NHRI, and do these assessments relate to the NHRI's formal institutional structure? How do NHRI heads themselves assess the institutional framework in which they work-do they see it as an aid, a hindrance, or as irrelevant? And what happens with NHRIs that lack important institutional safeguards? Can creative leadership carry out important activities even in the absence of an explicit mandate, or does the lack of formal safeguards significantly compromise their efforts? Finally, do we see dynamic effects, where virtuous (or vicious) cycles develop over time?

In an ideal world, we would compare otherwise identical NHRIs that differ only in the presence (or absence) of particular design safeguards. In practice, country cases tend to differ along multiple dimensions. One way to address this is to try to pick shadow cases conservatively. That is, shadow cases (i.e. cases lacking the safeguards we study) should be no less democratic, no less respectful of human rights, and no poorer than our main cases (cases with the safeguards we study). This is because each of these factors (and especially democracy) could make it easier for an NHRI to carry out its functions effectively, and we want to avoid attributing to formal safeguards what should be attributed to a favorable context.

In addition, in an ideal world, the presence (or absence) of such safeguards would be randomly assigned. Random assignment would help us set aside a plausible alternative explanation: that NHRIs with more formal safeguards are set up by governments that are especially keen to improve human rights, and would improve human rights performance regardless of NHRI activities.

An unusual feature of NHRI design allows us to move closer to this random assignment ideal than is typical for observational work. In the early 1990 s, the UN proposed a template for NHRI design - the Paris Principles. This template emphasized promotive functions, and deemphasized protective functions. This was done by mistake-Paris Principle drafters were not aware of a robust Ibero-American human rights ombudsman tradition with strong protective functions. ${ }^{94}$ Because this international template was highly influential, NHRIs set up after Paris were much more likely to include promotive functions, and much less likely to include protective functions, than NHRIs set up earlier. ${ }^{95}$ We therefore compare countries that adopted NHRIs shortly after Paris, to countries that adopted NHRIs shortly before Paris, as in many cases design choices are heavily influenced by international fashion.

\section{A. NHRIs With and Without Protective Safeguards in Latin America}

Our South American case studies in this section highlight the importance of protective design features, specifically the ability of NHRIs to handle individual complaints. We use a most-similar research design to study two otherwise similar cases that vary on the independent

\footnotetext{
${ }^{94}$ Linos \& Pegram, The Language of Compromise, supra note 7, at 599.

${ }^{95}$ Linos \& Pegram, Architects of Their Own Making, supra note 8, at 1110, 1121; Linos \& Pegram, supra note 7, The Language of Compromise, at 601-02.
} 
variable: complaint-handing powers (see Table 4). Importantly, the reason for variation on this design feature is quasi-exogenous. Most Latin American NHRIs, including the Peruvian case we study, included complaint-handling safeguards because they copied the Iberian Ombudsman template. These bodies were set up before the UN endorsed the Paris Principles. In contrast, the Chilean NHRI, set up after Paris, lacked this safeguard, because Chile followed the new dominant international model.

TABLE 4

Case Study SElection Overview

\begin{tabular}{|l|l|l|l|l|l|l|}
\hline & Date & Region & Office Type & $\begin{array}{l}\text { Independence } \\
\text { Safeguards }\end{array}$ & $\begin{array}{l}\text { Investigatory } \\
\text { Powers }\end{array}$ & $\begin{array}{l}\text { Promotional } \\
\text { Functions }\end{array}$ \\
\hline Chile & 2009 & $\begin{array}{l}\text { Latin } \\
\text { America }\end{array}$ & Commission & 4 & 2 & 3 \\
\hline Peru & 1993 & $\begin{array}{l}\text { Latin } \\
\text { America }\end{array}$ & Ombudsman & 5 & 5 & 3 \\
\hline
\end{tabular}

As with all such comparative exercises, Chile and Peru do not match perfectly and differ in important respects with regard to democratic performance. Notably, the Peruvian NHRI was established in the 1993 Constitution under an autocratic regime. It began operations in 1996, with the country transitioning to a fragile democracy in 2000 . The Chilean office began work in 2010 in a comparatively robust democratic setting, with Chile having transitioned to democracy over twenty years earlier. However, the challenge of human rights protection raises pressing concerns in both contexts. Given that Peru displays a weaker attachment to democratic practices and respect for rights, if context drove results, we would expect the Peruvian NHRI to be less effective than the Chilean body. Indeed, given the adverse democratic and rule of law conditions confronted by the Peruvian office it can be considered a "least likely case" for success. ${ }^{96}$ This expectation does not materialize.

Broadly, as summarized in Table 5, our case study of Peru highlights how the NHRI's ability to receive individual complaints has been an important source of authority. The Peruvian Ombudsman has proven adept at scaling up individual complaints to intervene in national policy debates and pushing for redress of systemic and structural rights violations. In contrast, the Chilean experience illustrates how a lack of complaint-handling powers has hampered the protective function of the NHRI. Notwithstanding important interventions on matters of national interest, the Chilean office has struggled to consolidate its image as a bridge between the state and citizen.

${ }^{96}$ John Gerring, Is There a (Viable) Crucial-Case Method?, 40 ComP. POL. STUD. 231, 234 (2007). 
TABLE 5

Summary of LATIN AMERICAN CASE STUdies

\begin{tabular}{|c|c|c|}
\hline & $\begin{array}{l}\text { Peruvian Human Rights } \\
\text { Ombudsman }\end{array}$ & $\begin{array}{l}\text { Chilean National Institute } \\
\text { for Human Rights }\end{array}$ \\
\hline $\begin{array}{l}\text { Investigatory } \\
\text { safeguards possessed } \\
\text { by the office? }\end{array}$ & $\begin{array}{l}\text { Power to investigate; Can } \\
\text { compel evidence/testimony; } \\
\text { Security facilities; Can refer } \\
\text { complaints; } \\
\text { complaints. }\end{array}$ & $\begin{array}{l}\text { Power to investigate; Can } \\
\text { refer complaints. }\end{array}$ \\
\hline $\begin{array}{l}\text { Why does the NHRI } \\
\text { have (or lack) } \\
\text { investigatory powers? }\end{array}$ & $\begin{array}{l}\text { No global model available-so } \\
\text { Peru copied Iberian } \\
\text { Ombudsman which had these } \\
\text { safeguards }\end{array}$ & $\begin{array}{l}\text { Chile copied new global } \\
\text { model (Paris Principles) which } \\
\text { lacked these safeguards }\end{array}$ \\
\hline $\begin{array}{l}\text { Does the NHRI make } \\
\text { use of its powers to } \\
\text { receive and } \\
\text { investigate individual } \\
\text { complaints? }\end{array}$ & $\begin{array}{l}\text { Yes. Very high volume of } \\
\text { complaints received and } \\
\text { processed. } \\
\text { complaints to generate political } \\
\text { impact. }\end{array}$ & $\begin{array}{l}\text { Yes. In the one area where } \\
\text { NHRI has investigatory } \\
\text { powers (torture) NHRI is very } \\
\text { active. } \\
\text { NHRI also active where given } \\
\text { powers-has made good use } \\
\text { of promotional powers. }\end{array}$ \\
\hline $\begin{array}{lr}\text { Do local actors } \\
\text { attribute } & \text { NHRI } \\
\text { success/failure to } \\
\text { presence (or absence) } \\
\text { of investigatory } \\
\text { safeguard? }\end{array}$ & $\begin{array}{l}\text { Yes. Observers highlight how } \\
\text { complaint-handling has } \\
\text { enabled the NHRI to address } \\
\text { systemic violations, as well as } \\
\text { build broad-based public } \\
\text { support. }\end{array}$ & $\begin{array}{l}\text { Yes. Observers attribute } \\
\text { challenges confronted by } \\
\text { NHRI to a lack of } \\
\text { investigatory capabilities. }\end{array}$ \\
\hline $\begin{array}{l}\text { How does government } \\
\text { respond to NHRI use } \\
\text { of its investigation } \\
\text { powers? }\end{array}$ & $\begin{array}{l}\text { Initially, Fujimori government } \\
\text { welcomes peripheral activity } \\
\text { (e.g. challenges to utility } \\
\text { pricing) but resists challenges } \\
\text { to core state interests (e.g. } \\
\text { security). Transition to } \\
\text { democracy lessens resistance } \\
\text { initially, although conditions } \\
\text { have deteriorated markedly } \\
\text { since } 2003 \text {. }\end{array}$ & $\begin{array}{l}\text { NHRI has encountered robust } \\
\text { resistance from conservative } \\
\text { politicians and the security } \\
\text { sector to its work on torture. } \\
\text { Successive and severe budget } \\
\text { cuts between } 2011 \text { and } 2013 \\
\text { are indicative of a lack of } \\
\text { political support for the office. }\end{array}$ \\
\hline $\begin{array}{l}\text { Does } \\
\text { presence/absence of } \\
\text { institutional } \\
\text { safeguards create } \\
\text { virtuous/vicious } \\
\text { feedback loops? }\end{array}$ & $\begin{array}{l}\text { Yes. Volume of individual } \\
\text { complaints grew over time as } \\
\text { complaint resolution gets } \\
\text { media publicity. Effective } \\
\text { investigative action by the } \\
\text { NHRI has reinforced } \\
\text { credibility of the office and its } \\
\text { leadership. }\end{array}$ & $\begin{array}{l}\text { Yes. Absence of complaint- } \\
\text { handling powers has } \\
\text { weakened NHRI in budget } \\
\text { negotiations. } \\
\text { investigative jurisdiction has } \\
\text { also diminished public } \\
\text { engagement and visibility of } \\
\text { the office. }\end{array}$ \\
\hline
\end{tabular}




\section{B. Peruvian Human Rights Ombudsman}

Established in 1993 by the autocratic regime of President Alberto Fujimori (1990-2000) in an effort to placate international critics, the Peruvian NHRI (human rights ombudsman) nevertheless quickly became, practically, the sole democratic state agent of accountability. ${ }^{97}$ Following democratic transition in 2000, the NHRI adapted to its new institutional context, described as holding "a solid political position not only in public life in general, but also with regard to the respect that it commands from other state institutions." 98 As evidenced in this study, and affirmed elsewhere, ${ }^{99}$ the authority of the Peruvian ombudsman hinges in large part on its ability to instrumentalize an individual complaints mechanism to facilitate citizen access to administrative redress, as well pursue high-impact accountability activities.

\section{Explaining the robust investigative powers of the Peruvian NHRI}

The Peruvian office is included in the 1993 Constitution. Constitutional provisions of independence and powers are robust. The NHRI's mandate comprises two primary areas: to defend the constitutional and fundamental rights of persons and to oversee the performance of the state administration. ${ }^{100}$ Public entities are legally obliged to cooperate with its investigations. ${ }^{101}$ Although the NHRI has no powers of enforcement, it can initiate a range of legal actions. ${ }^{102}$ The office can also present draft legislation, advise on existing legislative projects, and issue annual reports and recommendations. ${ }^{103}$ Importantly, powers of investigation include authority to launch investigations ex officio or on receipt of complaints. ${ }^{104}$

A political act of good faith to the international community, the 1993 Constitution contained a variety of democratic innovations. The new NHRI did not provoke widespread discussion, enjoying as it did both domestic antecedent within the prosecutor's office and strong international support. ${ }^{105}$ The World Bank Lima office was particularly engaged in lobbying for the office, providing $\$ 31.6$ million to be distributed between the judiciary and the NHRI in late 1997. ${ }^{106}$ The introduction of the office to the Peruvian context can be placed in a wider international trend toward global diffusion of liberal regulatory structures during the 1990 s. $^{107}$

\footnotetext{
${ }^{97}$ See Thomas Pegram, Accountability in Hostile Times: The Case of the Peruvian Human Rights Ombudsman 1996-2001, 40 J. LATIN AM. STUD. 51 (2008).

${ }^{98}$ Uggla, supra note 14, at 446.

99 Thomas Pegram, Weak Institutions, Rights Claims and Pathways to Compliance: The Transformative Role of the Peruvian Human Rights Ombudsman, 39 OXFORD DeV. STUD. 229, 236 (2011).

${ }^{100}$ Constitución Política del Perú [Political Constitution of Peru], Dec. 31, 1993, Art. 162.

${ }^{101}$ Law No. 26520, Art. 26, Ley Orgánica de la Defensoría del Pueblo (Organic Law of the Office of the Ombudsman), Agosto 8, 1995 (Peru).

${ }^{102} I d$. Art. 9.

${ }^{103}$ Id. Arts. 9, 27.

${ }^{104} I d$. Art. 9 .

${ }^{105}$ Interview with Samuel Abad, former Deputy Ombudsman for Constitutional Affairs, Defensoría del Pueblo (Peruvian NHRI), in Lima, Peru (July 14, 2005).

${ }^{106}$ Email from Daniel Cotlear, Country Sector Leader, The World Bank, to author (Feb. 21, 2006, 04:04 EST) (on file with author).

107 See Thomas Pegram, Diffusion Across Political Systems: The Global Spread of National Human Rights Institutions, 32 Hum. RTS. Q. 729 (2010). See generally KATERINA LinOS, THE DEMOCRATIC FOUNDATIONS OF Policy Diffusion: How HeAlth, FAmily AND EMPloyment Laws SpREAD ACross CounTries (2013); Katerina Linos, Diffusion Through Democracy, 55 AM. J. POL. SCI. 678 (2011).
} 
It is widely accepted among Latin American experts that Article 54 of the 1978 Spanish Constitution provides the "true paradigm" for the Iberian human rights ombudsman. ${ }^{108}$ The Spanish ombudsman emulates the Swedish classical ombudsman in granting extensive investigative prerogatives and complaint-handling powers. But in a novel twist, it also incorporates human rights as an explicit standard of control. The legacy effect of this international diffusion story is apparent in the design and reception of the Latin American Ombudsman, initially viewed as "an institution of administrative law . . . responsible for attending to cases of maladministration in order to achieve, through persuasion, remedy for those citizens affected." 109 Its human rights function was not well-understood.

There appears to be a general consensus among observers that Fujimori and his advisors had little notion of the role that the NHRI would eventually play in upholding the constitutional order and human rights. ${ }^{110}$ As the first Ombudsman elaborates:

You have to understand, in 1993 nobody really understood what the Ombudsman was and even less, gave it any importance. I had lived in Mexico and Central America, where the institution first began - in Guatemala. From this experience, I had a good idea of its potential. ${ }^{111}$

The main goals of the regime having been achieved, little attention was paid to such a peripheral innovation. ${ }^{112}$ In addition, the NHRI was considered a potentially useful addition to their economic objectives. The incorporation of such a modern institution dedicated to affirming citizens' rights would, it was hoped, symbolize a break with a succession of highly discredited administrations, as well as ameliorate the social cost of neoliberal policies. ${ }^{113}$ Despite the presence of formal democratic protections, once the constitution of 1993 began to function, it quickly became apparent that the "rules of the game" were distinctly in Fujimori's favor. ${ }^{114}$ Nevertheless, as the following section details, the Peruvian NHRI did not play by the Fujimori regime rules, tapping instead into a powerful source of independent authority derived from its ability to receive complaints.

\section{The impact of robust investigative powers on the Peruvian NHRI}

Activating its mandate to investigate individual complaints emerged as a core strategic focus for the Peruvian NHRI. The office has experienced a progressive increase in caseload,

108 Jorge Santistevan, El Defensor del Pueblo en Iberoamérica (The Ombudsman in Latin America), in RETOS Actuales de las Instituciones Nacionales de Protección y Promoción de los Derechos Humanos (CurRent Challenges of National Institutions for the Protection AND Promotion of HuMAN Rights) 27, 31 (2004).

${ }^{109}$ Id. at 28. Across Latin America, all NHRIs adopted before the Paris Principles resembled the Spanish Ombudsmen in institutional design — these include Guatemala (1985), Mexico (1990), Honduras (1990), Colombia (1991), El Salvador (1991), Costa Rica (1992), Paraguay (1992), Argentina (1993), and Peru (1993).

${ }^{110}$ Email from Jorge Santistevan, former Ombudsman (1996-2000), Defensoría del Pueblo Perú (Peruvian NHRI), to author (Feb. 22, 2006, 14:28 GMT) (on file with author).

${ }^{111} I d$.

112 Interview with Abad, supra note 79.

${ }^{113}$ Interview with Marcial Rubio, former Minister for Education, Ministerio de Educación del Perú (Ministry of Education of Peru), in Lima, Peru (Sept. 7, 2005).

${ }^{114}$ CAtherine Conaghan, Fujimori’s Peru: Deception in the Public Sphere 25 (2005). 
from 16,478 cases in $1997,59,867$ in 2001 , and 130,616 in $2016 .{ }^{115}$ In part, this reflects an institutional supply and demand process. Increasing the supply of institutional channels often encourages demand, especially in a weak democratic setting where victims of human rights violations find that they have little recourse to justice.

The Peruvian NHRI has adapted its own working practices to manage complaint reception and investigation with a view to achieving impact, without being overwhelmed by the sheer volume of demand. Upon reception, the ombudsman operates a triage strategy with cases divided into (1) complaints (human rights violations requiring intervention), (2) petitions (potential violations related to omission by state officials or public service providers), and (3) consultations (cases received that fall outside the jurisdiction of the institution). Consultations made up 50 percent of total cases received in 2016, resulting in referral of individuals to the appropriate public entity. It is important to note that the formal obligation falling on the ombudsman is to attend and assist the complainant, but the duty of resolution falls on the public administration. ${ }^{116}$

Complaint-handling has posed both opportunities and challenges, particularly with regard to managing expectations in a context of institutional dysfunctionality. In meeting this challenge, complaint-handling has become an important focal point for informational campaigns, with the office issuing press releases informing the general public of complaints received and efforts to achieve their resolution. ${ }^{117}$ However, ombudsman officials acknowledge that more needs to be done to raise awareness of the office among the general population: "most Peruvians have a very unclear understanding of the state. Often, they only begin to gain that knowledge when they need help." 118

Civil society observers attribute the impact and legitimacy of the Peruvian NHRI in large part to high profile efforts to pursue resolution of individual and collective complaints. Indeed, the dramatic rise in complaints throughout the 1990s responds to high-profile and successful NHRI campaigns, such as the Ad Hoc Commission (the Commission). Established in August 1996, this ad hoc entity was charged with reviewing the sentences of thousands of innocent Peruvians in remand custody on alleged terrorism offences. The NHRI had been inundated with complaints from NGOs and prisoners' family members from day one. ${ }^{119}$ Credit for breaking a negotiation deadlock is largely attributed to the brinkmanship of the first Ombudsman, Jorge

115 See Defensoría del Pueblo Perú (Peruvian NHRI), Informes AnUAles (AnNuAl RePorts), available at http://www.defensoria.gob.pe/informes-publicaciones.php.

${ }^{116}$ Skype interview with Carlos Alza Barco, Director of the School of Government and Public Policy, Pontifical Catholic University of Peru (June 28, 2016).

117 See, e.g., Oficina de Prensa e Imagen Institucional, Defensoría del Pueblo Perú (Office of Press and Institutional Image, Peruvian NHRI), Defensoría del Pueblo Recogera Quejas de Pobladores en Chilca, San Vincent e Imperial (Human Rights Ombudsman Receives Complaints from the Community of Chilca, San Vicente, and Imperial) (Sept. 27, 2011), available at http://www.defensoria.gob.pe/modules/Downloads/prensa/notas/2011/NP277-11.pdf. See generally Notas de Prensa, Defensoría del Pueblo Perú (Press Release, Peruvian NHRI), Defensoría Advierte Riesgos en el Proyecto de ley de Reconstrucción (Ombudsman Warns of Risks in the Reconstruction Bill) (Apr. 23, 2017), at http://www.defensoria.gob.pe/portal-noticias.php.

118 Skype Interview with Federico Chunga, Chief of Staff, Defensoría del Pueblo Perú (Peruvian NHRI) (May 23, 2016).

${ }^{119} I d$. 
Santistevan. ${ }^{120}$ Images of released innocents received extensive media coverage, contributing to the profile of the ombudsman and cementing links with the Peruvian public. ${ }^{121}$

Cultivating a reputation for successful intervention upon complaint has also sheltered the NHRI from political attack as it has sought to expand its activities. ${ }^{122}$ Investigations pursued by the Peruvian ombudsman into complaints of human rights violations have often provoked governmental resistance, even hostility. Under autocratic government, a diverse set of political and civil violations were a significant part of total complaints received (disappearances, judicial malpractice, police misconduct, and prison conditions). Civil society organizations and international monitors provided vital support, as evident in the success of the Commission initiative. In turn, the ombudsman worked with non-governmental organizations (NGOs) to build legal cases on behalf of victims of alleged torture and other violations. ${ }^{123}$ The reactive element of the office's mandate proved fundamental, with the NHRI well-placed to scale up individual complaints to address systemic concerns, including the military justice system, torture, judicial reform, and freedom of the press. Perhaps most notoriously, the NHRI, in coordination with church groups and NGOs, exposed a systematic campaign of forced sterilization of indigenous women, resulting in international condemnation. ${ }^{124}$

Routine complaints also addressed a wide variety of governmental functions. A consistent 50 percent or more of all complaints during the 1990s concerned official omission or neglect, such as delays in paying pensions, wages, and social benefits. ${ }^{125}$ Complaints targeting newly privatized public services were also considerable, averaging 10 percent, and focused on steep tariffs, quality of service, and access. ${ }^{126}$ One former official recalls the dramatic effect of informing complainants that they were under no obligation to pay unfair or incorrect water charges prior to disputing the amount: "Suddenly, we had fifteen hundred complaints, the people were suddenly empowered against the administration. It was truly a cultural change and the complaints served to achieve this." ${ }^{127}$ On such issues the office also pursued investigations conducive to official cooperation and even endorsement. ${ }^{128}$ In turn, media exposure and national campaigns generated many more complaints.

Forceful rights advocacy on the part of the NHRI post-transition to democracy in 2000 has underpinned its enduring public support, but also provoked powerful adversaries. Under the transition government of Valentin Paniagua (2000-2001) the Peruvian ombudsman emerged as a key advisor on government policy. ${ }^{129}$ However, a brief democratic spring proved short-lived, with government relations deteriorating rapidly under the administrations of President Alan

120 See Gino Costa, Dos Años de la Comisión Ad-Hoc: Resultados y Perspectivas (Two Years of the Ad-Hoc Commission: Results and Perspectives), 1 ReV. De LA Defensoría DEL PueBlo 127 (1998).

${ }^{121}$ Pegram, Accountability in Hostile Times, supra note 97, at 74.

${ }^{122}$ A similar dynamic is apparent with respect to INDECOPI, the Peruvian administrative agency responsible for intellectual property and consumer protection. See Laurence R. Helfer, Karen J. Alter \& M. Florencia Guerzovich, Islands of Effective International Adjudication: Constructing an Intellectual Property Rule of Law in the Andean Community, 103 AJIL 1, 12 (2009).

${ }^{123}$ Interview with Ana Leyva, Environmental Officer, FEDEPAZ, in Lima, Peru (Aug. 23, 2005).

${ }^{124}$ See María Mamerita Mestanza Chávez v. Peru, Case 12.191, Inter-Am. Comm'n H.R., Report No. 71/03, OEA/Ser.L/V/II.118 (2003).

${ }^{125}$ Defensoría Del Pueblo (Peruvian NHRI), Informe ANuAl (ANNUAl REPORT) 339 (1998).

${ }^{126}$ Id.

127 Skype interview with Carlos Alza Barco, supra note 116.

${ }^{128}$ Defensoría del Pueblo Insta a Sunat Colaborar en Procesos Judiciales Sobre Alimentos (Ombudsman Urges Sunat to Collaborate in Trials Concerning Food), EXPRESO (Nov. 18, 1999) (on file with author).

${ }^{129}$ See Pegram, Weak Institutions, Right Claims and Pathways to Compliance, supra note 99, at 236. 
Garcia (2006-2011) and President Ollanta Humala (2012-2016), both of whom were themselves implicated in serious human rights violations.

The ombudsman has refused to back down in the face of government obstruction on highprofile issues ranging from forced sterilization to torture, transparency reform, and military conscription. ${ }^{130}$ A 2012 legislative decree enforcing military conscription through public lottery and imposing substantial fines for non-compliance provoked a flood of complaints to the ombudsman. ${ }^{131}$ In response, the office issued a legal opinion declaring the decree unconstitutional and called for its suspension until the Ministry of Defense had conducted a review. This proposal was rejected. The ombudsman then successfully argued an emergency petition (amparo) before the Superior Court in Lima, suspending the lottery. This successful action was strongly denounced by the president himself. ${ }^{132}$ Nevertheless, hostility does not characterize interactions with the executive in other policy areas. ${ }^{133}$

More generally, in recent years the ombudsman has continued to pursue resolution of complaints, making use of new pockets of cooperation. The ombudsman publicizes data on the level of official cooperation with recommendations stemming from complaints. Time series data published by the office itself from 2002 to 2007 reveals that 59.7 percent of all complaints actioned "received a positive response" from the corresponding state agency. ${ }^{134}$ This figure stood at 67 percent in 2016. Such actions have also led to emulation effects within the public administration, with the National Pension Office (ONP) establishing its own complaint reception and resolution unit, which regularly meets with ombudsman technical personnel to expedite cases. Complaints to the ombudsman against the ONP have subsequently fallen by almost 50 percent. ${ }^{135}$

The NHRI has continued to scale up individual complaints to address systemic concerns, reflecting an evolving rights landscape. A growing volume of complaints refer to structural violations of an economic, social, and environmental nature. ${ }^{136}$ Tackling such issues often entails a different mode of intervention, with the ombudsman pursuing resolution principally through dialogue and technical cooperation, as opposed to (what would likely be protracted) legal action. Importantly, timely intervention on local issues has also reinforced the profile of the office as responsive to the needs of inhabitants. In the wake of devastating flooding in Peru in early 2017,

${ }^{130}$ Interview with Eduardo Vega, former Ombudsman (2011-2016), Defensoría del Pueblo Perú (Peruvian NHRI), in Brussels, Belgium (June 4, 2015).

${ }^{131}$ Legislative Decree No. 1146, Legislative Decree Amending Act No. 29248, Military Service Act, El Peruano (Dec. 11, 2012) (Peru).

132 See J. Cok, Ollanta Humala Criticó al Poder Judicial y a la Defensoría por Suspender Sorteo del Servicio Militar (Ollanta Humala Criticized the Judiciary and the Ombudsman for Suspending the Military Service Lottery), DIARIO CORREO (June 18, 2013), at http://diariocorreo.pe/politica/ollanta-humala-critico-al-poder-judicial-y-a92990.

${ }^{133}$ Presidente Ollanta Humala Oficializó Categorización de Sierra del Divisor como Parque Nacional (President Ollanta Humala Officialized Categorization of Sierra del Divisor as a National Park), MINISTERIO DEL AMBIENTE $\begin{array}{lllllll}\text { MinisTRY OF } & \text { THE } & \text { ENVIRONMENT) } & \text { (Nov. } & 7, & \text { 2015), }\end{array}$ http://www.minam.gob.pe/peruclimatico/2015/11/07/presidente-ollanta-humala-oficializo-categorizacion-de-sierradel-divisor-como-parque-nacional; see also Supreme Decree No. 014-2015-MINAM (Nov. 9, 2015) (Peru).

${ }^{134}$ See Defensoría Del Pueblo PERÚ (PERUVIAN NHRI), supra note 115.

135 Skype Interview with Fernando Castañeda, Ombudsman for Constitutional Affairs, Defensoría del Pueblo Perú (Peruvian NHRI) (June 13, 2016).

${ }^{136}$ DEFENSORÍA DEL PUEBlo (PERUVIAN NHRI), INFORME ANUAL (ANNUAL REPORT) (2014) 
the ombudsman was quick to coordinate an emergency response in response to complaints by those affected. ${ }^{137}$

Our Peruvian case study demonstrates a range of positive feedback loops attributable to an NHRI's ability to receive individual complaints. It has provided impetus for the ombudsman to enhance access and availability of services to the public; special protection to designated vulnerable groups; and informational campaigns through the media. ${ }^{138}$ It has also served to legitimate the organization in the eyes of the public. The intention behind the creation of the NHRI may have been to install a palliative institutional placebo. However, astute media engagement on complaint resolution has established a robust institutional image of efficacy. Success and publicity in fields such as utility regulation has further empowered the ombudsman to enter sensitive policy domains, including security, as well as move from individual complainthandling to demands for systemwide reforms.

There are also important interaction effects in play, in particular between complainthandling and decentralization of operations. The ombudsman was established with a plan to "progressively introduce offices in each departmental capital throughout Peru."139 There are currently thirty-eight decentralized offices located throughout the country. In 2016, 63 percent of complaints were received by regional offices outside Lima. ${ }^{140}$ Growth in the volume of complaints, coupled with the resource demands of decentralization, has also provided the ombudsman with important leverage in budget negotiations. Budget increases from $\$ 4.4$ million in 2001 to $\$ 13.6$ million in 2009, in a context of public sector cuts, is attributed to the office's decentralized reception of complaints ${ }^{141}$ and the negotiation skills of successive ombudsmen. ${ }^{142}$ The office's budget in 2016 was $\$ 18.1$ million. ${ }^{143}$

In a country where the state has traditionally neglected the institutional sphere of representative democracy, the logic pursued by NHRI officials to empower citizens against the public administration by encouraging them to claim their "right to complain" has had a powerful cultural impact. ${ }^{144}$ The ombudsman has consistently enjoyed among the highest public approval ratings of any state institution. ${ }^{145}$ According to one civil society observer:

137 See Defensoría del Pueblo Perú (Peruvian NHRI), Reporte de Intervenciones Defensoriales

(REPORT ON DEFENSE INTERVENTIONS) (2017), available at
http://www.defensoria.gob.pe/emergenciasydesastresnaturales/images/repo_interv_dp.pdf.

${ }^{138}$ Skype interview with Fernando Castañeda, supra note 135.

139 Law No. 26520, Art. 32, Ley Orgánica de la Defensoría del Pueblo (Organic Law of the Office of the Ombudsman), Agosto 8, 1995 (Peru).

140 Defensoría del Pueblo (Peruvian NHRi), Informe Anual (ANnuAl RePort) 32 (2016).

${ }^{141}$ Interview with Walter Alban, former Ombudsman, Defensoría del Pueblo Perú (Peruvian NHRI), in Lima, Peru (June 23, 2008).

${ }^{142}$ Interview with Ismael Muñoz, Professor of Economics, La Catolica University, in Lima, Peru (June 19, 2008).

143 See Defensoría del Pueblo Perú (Peruvian NHRI), supra note 115 (budget data available in annual reports.); see also Xe, Current and Historical Rate Tables, at www.xe.com/currencytables (For historical conversion rates).

${ }^{144}$ Skype interview with Carlos Alza Barco, supra note 116.

${ }^{145}$ See Pegram, Accountability in Hostile Times, supra note 97, at 74; Pegram, Weak Institutions, Right Claims and Pathways to Compliance, supra note 99, at 234. 
The ombudsman has gained public support above all because it listened to the people. In a country where nobody has ever listened to the people, the very fact that someone could go to their offices and be heard was very important. ${ }^{146}$

The success of the NHRI has also set in motion less desirable feedback loops. The office has been subject to attempts by congress to install partisan individuals, thwarted repeatedly by public outcry, most dramatically resulting in street protests in 2013. ${ }^{147}$ However, in September 2016, with the Fujimori-aligned Popular Force (Fuerza Popular) party commanding an absolute majority in Congress, the NHRI finally succumbed to political pressure. ${ }^{148}$ The successful candidate was appointed through an opaque procedure with no opportunity for public consultation and is linked to past controversies. ${ }^{149}$

However, despite widespread misgivings, the office continues to function effectively, as is indicated in its rapid response to devastating floods in early 2017. In December 2016, it received the highest public approval rating of any state institution. ${ }^{150}$ Problematic appointments may, under adverse conditions, prove difficult to ward against, irrespective of formal institutional design. However, as this comparative study highlights, such an outcome is neither inevitable nor irreversible. Formal safeguards support and protect an ombudsman committed to the effective functioning of the institution. The Peruvian NHRI has achieved much and the protection imperative underlying each of the thousands of complaints it continues to receive remains undiminished, as does its public support.

\section{Chilean National Institute of Human Rights}

The Chilean NHRI lacks explicit investigative faculties, such as the ability to compel evidence or receive individual complaints. In large part, this is due to the office being established in accordance with the Paris Principles, which only weakly recommends these protective features. Even though the Chilean office was set up in a less challenging political environment than in Peru, it has not been able to consolidate its protective profile or remedy important systemic protection deficits. By comparing these two cases, the study substantiates the important effects on institutional outcomes of formal provisions of investigation, particularly individual complaint-handling.

\section{Explaining the limited investigative powers of the Chilean NHRI}

Chile emerged from a protracted period of authoritarian government and systematic human rights violations in 1990. Human rights defenders point to the legacy effects of this experience in a lack of progress in enhancing access to justice and the entrenched exclusion of

\footnotetext{
${ }^{146}$ Interview with Marcial Rubio, supra note 113.

147 Carlos Noriega, Golpe de los Indignados en Perú (Blow of the Indignados in Peru), PÁGINA12 (July 25, 2013), at https://www.pagina12.com.ar/diario/elmundo/4-225231-2013-07-25.html.

148 Fujimoristas Hold Key to Ombudsman Election, PERU SUPPORT GROUP (Sept. 3, 2016), at http://www.perusupportgroup.org.uk/article-1173.html.

${ }^{149}$ New Ombudsman Threatens to Downplay Human Rights Protection, PERU SuPPORT GrouP (Sept. 18, 2016), at http://www.perusupportgroup.org.uk/article-1186.html.

${ }^{150}$ The ombudsman received an approval rating of $52 \%$ in December 2016 , as compared to $18 \%$ for the judiciary, at http://www.andina.com.pe/agencia/noticia-el-51-confia-el-gobierno-segun-encuesta-pulso-peru-datum643652.aspx.
} 
traditionally marginalized groups within Chilean society. ${ }^{151}$ Torture and arbitrary detention persists and Chile also displays one of the highest levels of incarceration in Latin America. ${ }^{152}$

At the close of 2009 the Chilean Senate approved the creation of the National Institute for Human Rights (INDH). ${ }^{153}$ Robust legal prerogatives regarding grave human rights violations and custodianship over the Chilean Truth and Reconciliation Commission's legacy reflect its regional and domestic setting. But a formal orientation toward promotion over protection, and the omission of important protection faculties is a significant departure from the Iberian human rights ombudsman. Independence provisions also do not follow regional precedent, lacking constitutional entrenchment, the INDH is comprised of a director and seven councilors, including two appointed by the president. ${ }^{154}$

The Chilean Institute stands alone among its regional NHRI peers, with no explicit provision to receive complaints. ${ }^{155}$ What explains the lack of complaint-handling powers in this case? Political opposition to a robust human rights structure is informed, above all, by powerful conservative political forces. A dense institutional apparatus served as the pretext to dismiss the need for a human rights ombudsman. In contrast, progressive forces argued that such a body was essential. In the end, progressives and conservatives compromised on legislation that mirrored the international template closely; it included almost everything strongly recommended in the Paris Principles, but excluded other features that were common in Latin America but not strongly recommended in the international template.. Chile's NHRI incorporated safeguards strongly recommended in the Paris Principles, but left out the weakly recommended complaint-handling mechanism. ${ }^{156}$ In related work, we explain how legislative debate centered on the Paris Principles, and how the Chilean government pointed to the international template to justify key omissions, notably the exclusion of complaint-handling. ${ }^{157} \mathrm{We}$ also document civil society activists and UN officials, including the UN Representative of the High Commissioner for Human Rights in Latin America who took the unusual position of arguing against the adoption of the UN-promulgated Paris Principles, and in favor of regional models. ${ }^{158}$

Nevertheless, these advocates lost, and the legislation does not grant the NHRI an explicit mandate to receive, process, investigate, or adopt recommendations with respect to individual complaints. Opponents to complaint-handling continue to assert that Chile's institutional framework sufficiently robust. Others claim that the absence of formal authorization does not preclude effective complaint-handling. However, as the next section details, the Chilean experience throws such claims into doubt. Evidence supports the counterfactual claim that explicit provision for complaint-handling is likely to have significantly enhanced the impact of the Chilean Institute.

${ }^{151}$ Universidad Diego Portales, Informe Anual de Derechos Humanos de la Universidad Diego Portales (ANNUAL REPORT ON HuMAN RightS BY THE DiEGO PORTALES UNIVERSITY) 559-60 (2008).

${ }^{152}$ Karinna Fernández Neira \& Par Engstrom, Torture Incidence and Prevention in Chile: 1985-2014, in DOES TORTURE PREVENTION WORK? 143 (Richard Carver \& Lisa Handley eds., 2016).

${ }^{153}$ Law No. 20405, Law of the National Institute of Human Rights, Diciembre 10, 2009, Diario Oficial [D.O.] (Chile).

${ }^{154}$ Law No. 20405, Art. 6, Law of the National Institute of Human Rights, Diciembre 10, 2009, Diario Oficial [D.O.] (Chile).

${ }^{155}$ Id. Art. 3(5).

${ }^{156}$ Linos \& Pegram, The Language of Compromise, supra note 7 at 612.

${ }^{157} \mathrm{Id}$. at $612-13$.

${ }^{158} \mathrm{Id}$. at $613-14$. 


\section{The impact of limited investigative powers on the Chilean NHRI}

The INDH is not without investigative prerogatives. Notably, the Institute can initiate legal action before the courts with regard to five specific crimes: genocide, crimes against humanity, torture, forced disappearances, and illegal trafficking of migrants. ${ }^{159}$ The INDH has pursued multiple legal actions in defense of torture victims, with notable success. ${ }^{160}$ It has also, on its own initiative, interpreted its mandate to successfully launch a program of prison visits, including in response to complaints received by prisoners themselves. Civil society actors consider this work significant, especially in a context of impunity. ${ }^{161}$ Outside of a proscribed set of egregious violations, the powers of the Institute lie principally in the arena of agenda setting. The INDH has begun to experiment with expanding its remit beyond the strict parameters of its founding legislation, notably emulating practices developed by the Peruvian Ombudsman, including observation of social protests and initiating an ambitious decentralization program in 2015. Such efforts may help justify a formalization of complaint-handling powers. However, decentralization of operations, coupled with an absence of complaint-handling powers outside a proscribed set of crimes, may also generate negative feedback effects: above all, the inflated expectations of individuals seeking out the INDH as a venue of last resort, only to find that it can offer little meaningful redress.

The lack of explicit complaint-handling powers has posed significant challenges. In the end, the INDH can do little more than report the violation to the responsible state official. As one observer put it: "Because the law is ambiguous, the actions of the INDH are also ambiguous."162 The INDH is sensitive to this concern. In response, it has interpreted the instruction contained in Article 3(6) to "receive any information" as also including reception of complaints. A Citizens Attention Unit was established in 2015 and has begun to issue reports on complaints received, reporting 1,760 complaints attended to in the first half of the year. ${ }^{163}$ The largest set of cases (431) refers to maladministration, principally involving detainees and public service provision. The second largest set of cases (373) refers to historical violations.

The incipient practice of receiving complaints leads some NHRI officials to dismiss the absence of explicit complaint-handling authority as a "non-issue." 164 However, the volume of complaints received are strikingly low when compared to complaint volumes in Peru and other Latin American states whose NHRIs have formal complaint-handling mandates. Moreover, no

159 Law No. 20405, Art. 3(5), Law of the National Institute of Human Rights, Diciembre 10, 2009, Diario Oficial [D.O.] (Chile).

160 See, e.g., Natalia Cruces, Recurso de Amparo a Favor de Internos Contra Maltratos y/o Tortura de Gendarmería (Habeas Corpus in Favor of Inmates for Mistreatment and/or Torture by the Prison Service), LA IZQUIERDA DIARIO (June 11, 2015), at http://www.laizquierdadiario.com/Recurso-de-Amparo-a-favor-de-internoscontra-maltratos-y-o-tortura-de-Gendarmeria?id_rubrique $=1201$.

161 COMISIÓN Ética CONTRA la TORTURA (ETHICAL COMMISSION AgAINST TORTURE), ¡NO A LA TORTURA! A NADIE EN Ningún LUGAR Y EN NOMBRE DE NADA (NO TO TORTURE! TO NO ONE ANYWHERE AND IN NO ONE'S NAME) 163 (June 2011), available at https://notascect.files.wordpress.com/2011/06/2011-final-informecect_2011quimantc3ba.pdf.

${ }^{162}$ Skype Interview with Magdalena Garcés Fuentes, Human Rights litigator and former National Institute for Human Rights (INDH) official (Sept. 3, 2016).

163 InStituto Nacional De Derechos Humanos (NATiOnal Institute of Human Rights), Informe Atención de Personas (Report of CAre of People), Primer Semestre (First Semester) (2015) (on file with author) [hereinafter INDH 2015].

164 Commentary from Silvana Lauzán, Director of INDH Research Unit, at Diego Portales University, in Santiago, Chile (May 11, 2016). 
information is provided on complaint supervision, follow-up, or resolution. The INDH has used legal writs to partially circumvent this deficit, but only with respect to the specified crime of torture, with other violations of varying gravity falling by the wayside. Indeed, in 2010 the NHRI rejected official designation as the National Preventive Mechanism under the Optional Protocol to the Convention Against Torture (OPCAT) due to formal shortcomings. ${ }^{165}$

Formal structure limitations are acknowledged not only by NHRI staff, but also by the human rights community. Recognizing the important role of the INDH, Amnesty International (AI) nevertheless has called on the Bachelet government to establish a human rights ombudsman, noting the INDH's "continuing limitations, for example, the fact it can only pursue judicial actions in relation to those concrete cases defined by law." 166 Recent proposals to establish a sector-specific children's ombudsman, as well as an antidiscrimination body, also point to INDH deficiencies. Draft legislation for the children's ombudsman, tabled in 2015, was criticized for not contemplating "an autonomous complaints and claims system for children." 167 Domingo Lovera continues: "An 'individual complaints' [system] . . . can ensure that the voice of children is heard within our institutions. ${ }^{168}$ Exactly the principle problem affecting this group, is that for them the state administration is, generally, closed." In a study contemplating the creation of an antidiscrimination body, Albert Coddou McManus and Tomás Vial Solar argue that the INDH could take on this function but it would require legislative reform granting the body "powers or investigative faculties [and] reception of complaints or individual issues." "69 In short, when NHRI allies criticize the body and call for replacement institutions with complaint-handling powers, this underscores the importance of complaint-handling structures.

Specifically, observers highlight an important deficit in Chile's protection framework for human rights infractions that are not necessarily justiciable. Many of the complaints received by the INDH in 2015 fall into this category, including the withdrawal of welfare benefits to detainees, delays in pension administration, and medical negligence. ${ }^{170}$ In response, INDH officials point to the density of the institutional apparatus in Chile as providing significant, if not sufficient, pathways to remedy. ${ }^{171}$ However, agencies such as the Ministry of Interior, the pro bono Judicial Assistance branch, and the Nacional Service for the Consumer (SERNAC), may have nominal jurisdiction over human rights issues, but in reality they provide few effective remedies. ${ }^{172}$ Unlike in Peru, the Chilean NHRI also cannot rely on a highly mobilized human

165 InSTITUTO NACIONAL DE DEREChOS Humanos (NATIONAL InSTITUTE OF HuMAN Rights), InfORME ANUAL

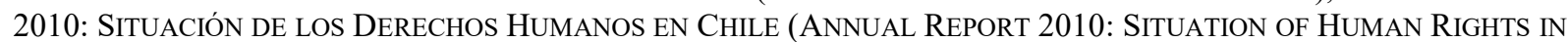
CHILE) 70 (2010).

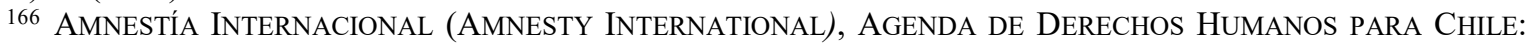
Periodo De Gobierno 2014-2017 (Human Rights Agenda For Chile: Government Period 2014-2017), available at $\mathrm{http}$ //amnistia.cl/wp-content/uploads/2015/02/Agenda-de-DDHH-para-Chile.pdf.

167 DOMINGO LOVERA \& UNICEF, IGUALDAD Y NO DISCRIMINACIÓN DE NIÑOS, NIÑAS Y AdOLESCENTES: NECESIDAD DE UN SisTEMA DE GARANTÍAS REFORZADAS (EQUALITY AND NON-DISCRIMINATION OF CHILDREN AND ADOLESCENTS: THE NEED FOR A SYSTEM OF ENHANCED GUARANTEES) 8 (2015), available at unicef.cl/web/wpcontent/uploads/2015/06/3-Garantias-reforzadas-31.pdf.

${ }^{168} \mathrm{Id}$. at 9.

169 Albert Coddou McManus \& Tomás Vial Solar, Estándares y Criterios para la Creación de un Órgano Antidiscriminación (Standards and Criteria for the Creation of an Anti-discrimination Body), ANUARIO DE DERECHO PÚBLICO (YEARBOOK OF PUBLIC LAW) 216, 233 (2013).

${ }^{170}$ INDH 2015, supra note 165.

${ }^{171}$ Skype interview with Silvia Lauzán, Director of Research Unit, Instituto Nacional De Derechos Humanos (National Institute of Human Rights) (Mar. 10, 2016).

${ }^{172}$ For example, although the Human Rights Program of the Ministry has a mandate to attend to serious human rights violations, it is unable to order reparations to victims or their families. 
rights community to engage in complaint supervision or effectively counter political backlash. ${ }^{173}$ As one former INDH functionary puts it:

The problem is acute in all of the cases which the INDH chooses not to take up or supervise, and there exist thousands of such cases in the country. In the background, no state institution exists which can take up many of these complaints, placing these individuals in a situation of absolute vulnerability. ${ }^{174}$

INDH officials do acknowledge such protection gaps, but insist that an obligation to receive and attend all individual complaints would quickly overwhelm their limited resources. ${ }^{175}$ This is a valid concern. Indicative of powerful opposition, the Institute was initially assigned $\$ 2.3$ million in 2010, but Congress allocated 34 percent less than the sum requested in 2011 and imposed further budget cuts in 2013. The absence of investigative powers has also likely had other negative effects, including hamstringing the INDH during budget negotiations. Many human rights ombudsmen, as evidenced in Peru, have seized upon their statutory requirement to attend to growing caseloads as necessitating greater resource allocation.

Opposition by conservative factions within Congress stems from the robust advocacy by the INDH on a wide range of high profile rights issues. ${ }^{176}$ In response, the institution has been subject to severe attacks. In May 2016, members of the right-wing Independent Democratic Union (UDI) party declared that the "human rights which [INDH Director] Señora Fríes promotes only serve to defend delinquents and masked men." 177 Subtler, but no less insidious attacks, have also been produced by private think tanks. ${ }^{178}$ Severe critiques of the limited effectiveness of the NHRI persist, in spite of a relatively favorable political environment. The INDH currently has a high-profile supporter in President Michelle Bachelet (2014-2018), as indicated by the appointment of a highly credible individual as the new INDH Director in 2016. ${ }^{179}$ However, a latent concern also arising from the absence of an explicit obligation to receive complaints focuses on INDH responsiveness being overly dependent upon the discretion of its executive (the Council and Directorship). The first Director, Dr. Lorena Fríes (2010-2016), is widely viewed as having performed well. However, the risk of capture is heightened by the fact that, similar to the Peruvian case, the INDH has been a lightning rod for political controversy.

${ }^{173}$ Many campaigning human rights NGOs disappeared during Chile's transition, viewed as out of step with the overriding objective of securing democracy. See Thomas C. Wright, Impunity, Human Rights, AND DEMOCRACY: CHILE AND ARGENTINA, 1990-2005, at 59 (2014).

${ }^{174}$ Skype interview with Magdalena Garcés Fuentes, supra note 164.

${ }^{175}$ Skype interview with Silvana Lauzán, supra note 166.

176 These include nationwide social protests, police violence, conflict between the state and the Mapuche people, and reconstruction following the earthquake of February 2010.

177 Juan Riquelme Díaz, La UDI Criticó Presupuesto del INDH de \$5 Mil Millones para "Defender a Encapuchados" (UDI Criticized \$5 Billion NHRI Budget for “Defending Masked Men”), EL MERCURIO (May 25, 2016), at http://www.soychile.cl/Valparaiso/Sociedad/2016/05/25/395441/La-UDI-critico-presupuesto-del-INDHde-5-mil-millones-para-defender-a-encapuchados.aspx.

178 José Francisco García \& Sergio Verdugo, Libertad y Desarrollo, Radiografía al Instituto Nacional de DD.HH (Libertad y Desarrollo, Radiography of the National Institute of Human Rights), INDH (2012), available at lyd.org/wp-content/uploads/2012/06/SI-INDH-versión-final.pdf.

${ }^{179}$ Movilh Celebra Elección de Branislav Marelic como Nuevo Director del INDH (Movilh Celebrates Election of Branislav Marelic as New NHRI Director), MOVILH (Aug. 2, 2016), at http://www.movilh.cl/movil-celebraeleccion-de-branislav-marelic-como-nuevo-director-del-indh. 
Our Chilean case study provides a powerful counterpoint to the Peruvian experience in highlighting the negative impact of omitting formal provisions of investigation, particularly complaint-handling. To be exact, individual complaints handling is formally limited to very grave violations - and it is only in these areas, notably torture, where the INDH has acted forcefully. Coupled with a highly restrictive mandate, this formal omission has hindered the ability of the Institute to consolidate its public profile as an accessible and effective rights protector. The NHRI has demonstrated ingenuity in seeking to overcome formal limitations. The absence of complaint-handling has made it difficult, however, for the Chilean office to execute basic functions, let alone expand its mandate or resist budget cuts. Observers also highlight additional vulnerabilities, including political pressure being brought to bear on the selection of cases and public disillusionment as individuals learn that the Institute cannot help them. In contrast to Peru where complaint-handling has served as a powerful instrument for consolidating profile and countering negative feedback, the Chilean NHRI has been denied this pathway to institutionalization. The study now turns to a different set of cases to examine the importance of a quite different set of formal provisions.

\section{NHRIs With and Without Promotion Safeguards in the Asia-Pacific Region}

We next turn to paired comparisons in the Asia-Pacific region, to study the presence (and absence) of promotive functions. Whereas our quantitative results revealed a robust correlation between investigatory powers and NHRI effectiveness, patterns were more mixed regarding promotive functions. Nevertheless, we investigate promotive functions through case studies, both because regressions can fail to reveal effects that only occur under particular circumstances, and because the UN Paris Principles place such emphasis on promotive powers.

We start with Malaysia. In this case, the NHRI was set up by an authoritarian regime in response to international pressure and there was little expectation that the office would be effective. Nevertheless, the NHRI was given all three promotive powers we study. Promotive powers came into fashion through the 1991 Paris Principles. ${ }^{180}$ Malaysia activated its NHRI soon thereafter, in 1999. They may have acceded to the international template because the governing regime did not see promotive powers as major threats. Nevertheless, we find that in this case, promotive powers allowed the NHRI to generate significant publicity around human rights concerns, even under adverse circumstances. However, it has proven more difficult to convert publicity into concrete reforms.

We also include the Philippines as a shadow case, to create a counterfactual and explore a similar commission without extensive promotive powers. The Philippine NHRI was set up in a setting that was no more hostile than the Malaysian context, and was generally similar in design. However, because it was activated in 1987, before the Paris Principles made promotive functions fashionable, it lacked a mandate to advise on legislation or to produce reports. Shadow cases should be selected so they differ on the main independent variable of interest, but are otherwise similar (see Table 6). The two NHRIs have comparable investigatory powers, but the Malaysian NHRI established after Paris has more extensive promotion powers.

That said, because case studies are never perfectly matched, and the number of cases is always small, we present them not to make robust causal inferences, but rather to probe the plausibility of the proposed mechanisms. A potential complication with our research design is that countries that established NHRIs before the international community pushed for them might

${ }^{180}$ Linos \& Pegram, Architects of Their Own Making, supra note 8, at 1121. 
have been more committed to seeing them succeed. Practically, this means that if anything, we should expect the Philippine NHRI to be more effective than its Malaysian counterpart, something that would lead us to underestimate (rather than overestimate) the effects of NHRI institutional safeguards.

TABLE 6

CASE StUdy OverVIEW

\begin{tabular}{|l|l|l|l|l|l|l|}
\hline & Date & Region & Office Type & $\begin{array}{l}\text { Independence } \\
\text { Safeguards }\end{array}$ & $\begin{array}{l}\text { Investigatory } \\
\text { Powers }\end{array}$ & $\begin{array}{l}\text { Promotional } \\
\text { Functions }\end{array}$ \\
\hline Malaysia & 1999 & $\begin{array}{l}\text { Asia- } \\
\text { Pacific }\end{array}$ & Commission & 3 & 5 & 3 \\
\hline Philippines & 1987 & $\begin{array}{l}\text { Asia- } \\
\text { Pacific }\end{array}$ & Commission & 2 & 5 & 1 \\
\hline
\end{tabular}

Our case studies allow us to show how institutional safeguards can be employed in different contexts, depending upon the commitment of NHRI leaders and opportunities encountered in governing structures. As summarized in Table 7, the Malaysian NHRI has produced a broad range of highly critical reports, ensuring media coverage, and facilitating civil society mobilization. Promotional activities have caused significant upset to ruling regimes, provoking strongly worded criticism. A lack of strong independence safeguards has led to outspoken commissioners being removed or their terms not renewed, and the NHRI had suffered multiple budget cuts. Despite adversity, the NHRI nevertheless has won some modest, but important, reform victories.

In contrast, in the Philippines, a lack of promotional protections has led the NHRI to focus on a different route to change-facilitating the prosecution of abuse perpetrators. This uphill battle produced few results. When one ambitious NHRI head briefly experimented with an alternative promotional strategy - as pursued in Malaysia - he was shut down by the country's Supreme Court, which found that the NHRI had exceeded its mandate. 
TABLE 7

Summary of Asia Pacific CASE Studies

\begin{tabular}{|c|c|c|}
\hline & $\begin{array}{l}\text { Iuman Rights Commission } \\
\text { f Malaysia (Suhakam) }\end{array}$ & $\begin{array}{l}\text { Philippines Commission on } \\
\text { Human Rights (CHR) }\end{array}$ \\
\hline $\begin{array}{l}\text { Promotional powers } \\
\text { possessed by the } \\
\text { office? }\end{array}$ & $\begin{array}{l}\text { dvise on legislation; annual } \\
\text { ports; } \\
\text { omotion. }\end{array}$ & Education and pr \\
\hline $\begin{array}{l}\text { Why does the NHRI } \\
\text { have (or lack) } \\
\text { promotional powers? }\end{array}$ & $\begin{array}{l}\text { Talaysia copied new global } \\
\text { odel (Paris Principles) which } \\
\text { quires NHRIs to possess a } \\
\text { nge of promotional powers. }\end{array}$ & $\begin{array}{l}\text { No global model was available } \\
\text { in 1987-so Philippines NHRI } \\
\text { designers drew inspiration } \\
\text { from public prosecutor model }\end{array}$ \\
\hline $\begin{array}{l}\text { Does the NHRI make } \\
\text { use of its powers to } \\
\text { advise on legislation, } \\
\text { issue reports, and } \\
\text { promote human rights } \\
\text { education? }\end{array}$ & $\begin{array}{l}\text { es. Promotional activities } \\
\text { ave been a centerpiece of the } \\
\text { HRIs activities since it began } \\
\text { perations in April } 2000 \text {. It has } \\
\text { everaged annual reports to } \\
\text { enerate political impact. }\end{array}$ & $\begin{array}{l}\text { Yes. In the one area where } \\
\text { NHRI has promotional powers } \\
\text { (education), NHRI has been } \\
\text { active. However, with some } \\
\text { exceptions, widely viewed as } \\
\text { having underperformed. }\end{array}$ \\
\hline $\begin{array}{l}\text { Do local actors } \\
\text { attribute NHRI } \\
\text { success/failure to } \\
\text { presence (or absence) } \\
\text { of promotional } \\
\text { safeguard? }\end{array}$ & $\begin{array}{l}\text { Yes. Observers highlight how } \\
\text { promotional campaigns have } \\
\text { forced the hand of government } \\
\text { (eventually) to address } \\
\text { systemic violations, as well as } \\
\text { providing a bridge between the } \\
\text { state and civil society. } \\
\text { However, others express } \\
\text { frustration at government } \\
\text { stonewalling. }\end{array}$ & $\begin{array}{l}\text { Yes. Observers attribute } \\
\text { challenges confronted by } \\
\text { NHRI to a legalistic approach } \\
\text { adopted by successive } \\
\text { chairpersons borne of a formal } \\
\text { design weighted toward a } \\
\text { prosecutorial model of } \\
\text { intervention. }\end{array}$ \\
\hline $\begin{array}{l}\text { How does government } \\
\text { respond to NHRI use } \\
\text { of its promotional } \\
\text { powers? }\end{array}$ & $\begin{array}{l}\text { The NHRI has confronted } \\
\text { official indifference and } \\
\text { backlash, especially on security } \\
\text { concerns. Progress has been } \\
\text { observed in other areas (e.g., } \\
\text { indigenous rights). The NHRI } \\
\text { adeptly exploited the political } \\
\text { opening presented by the } 2008 \\
\text { elections to press its advantage. }\end{array}$ & $\begin{array}{l}\text { Government has been } \\
\text { intermittently receptive to } \\
\text { education mandate, especially } \\
\text { training of security personnel. } \\
\text { However, the office has } \\
\text { encountered robust resistance } \\
\text { from the courts. Severe budget } \\
\text { cuts in } 1997 \text { and scheduled for } \\
2017 \text { are also indicative of a } \\
\text { lack of political support. }\end{array}$ \\
\hline $\begin{array}{l}\text { Does } \\
\text { presence/absence of } \\
\text { promotional powers } \\
\text { create virtuous/vicious } \\
\text { feedback loops? }\end{array}$ & $\begin{array}{l}\text { Yes. Effective use of its } \\
\text { promotional mandate has } \\
\text { emboldened NHRI leadership } \\
\text { and set expectations vis-à-vis } \\
\text { domestic support } \\
\text { constituencies. Promotional } \\
\text { activities have reinforced the }\end{array}$ & $\begin{array}{l}\text { Yes. Absence of robust } \\
\text { promotional powers has } \\
\text { weakened NHRI in terms of } \\
\text { accountability and popular } \\
\text { credibility. Experimentation } \\
\text { with promotional mandate in } \\
1994 \text { subject to official }\end{array}$ \\
\hline
\end{tabular}


credibility of the office, but backlash, prompting a retreat they have also provoked from such activity until 2008. official hostility.

\section{E. The Malaysian Human Rights Commission}

The autocratic government of Mahathir Mohamad (1981-2003) established the Human Rights Commission (Suhakam) in 1999, amidst growing domestic pressure for public accountability. ${ }^{181}$ The Malaysian NHRI displays important formal limitations, especially in terms of independence safeguards. Nevertheless, it has deployed a broad suite of promotional functions to, at times, effectively mobilize human rights concerns at the domestic level. Described as a "genuinely new institutional initiative in accountability," the office has adopted positions markedly different to government on a range of human rights issues. ${ }^{182}$ In contrast to the Philippine experience, robust promotional powers have enabled the Malaysian NHRI to engage in a broad array of high-impact activities and deflect political attacks. Third party mobilization, individual leadership, and international pressure emerge as important additional factors in explaining the relative success of the Malaysian office.

\section{Explaining the robust promotional powers of the Malaysian NHRI}

Suhakam is established in legislation and includes a mandate to promote human rights through education: advise on legislation; recommend ratification of international instruments; and issue reports based on public inquiries. ${ }^{183}$ Receptiveness to international pressure is apparent. By 1999, the Paris Principles were widely accepted as the benchmark standard for NHRI design. As Amanda Whiting remarks, "Malaysia could have claimed to conform to those standards or argued against them, but it was unthinkable to ignore them."184

Despite declarations by the foreign minister at the time that Suhakam "was firmly based on the Paris Principles," 185 the office displays a number of restrictions that are problematic from a Paris Principles-compliance perspective. It is unique among NHRIs in initially granting only a two-year term in office with no security of tenure; it is accountable to the minister of foreign affairs; appointment is on recommendation of the prime minister; and it labors under a restricted human rights mandate (those rights included in Part II of the Constitution). ${ }^{186}$

Government may have viewed Suhakam as principally an international public relations exercise. However, NHRI adoption in Malaysia would also be informed by the popular demands of civil society to rein in rampant abuses of state power. ${ }^{187}$ The creation of Suhakam was

\footnotetext{
${ }^{181}$ Human Rights Commission of Malaysia Act (Act No.597/1999) (Malaysia).

182 Garky Rodan \& CARoline Hughes, The Politics of AcCountability in Southeast Asia: The DOMINANCE OF MORAL IDEOLOGIES 62 (2014).

${ }^{183}$ Human Rights Commission of Malaysia Act, supra note 183. See also Li-ann Thio, Panacea, Placebo, or Pawn? The Teething Problems of the Human Rights Commission of Malaysia (SUHAKAM), 40 GEO. WASH. INT'L L. REV. 1271 (2009).

184 Amanda Whiting, Situating Suhakam: Human Rights Debates and Malaysia's National Human Rights Commission, 39 STAN. J. INT’L L. 59, 74 (2003).

${ }^{185} \mathrm{Id}$. at 75

${ }^{186}$ Human Rights Commission of Malaysia Act, supra note 183.

187 Garry Rodan \& Caroline Hughes, The Politics of Accountability in Southeast Asia: The DOMINANCE OF MORAL IDEOLOGIES 58 (2014).
} 
announced in March 1999; by July, legislation to establish the Human Rights Commission was before parliament; and it opened its doors in early 2000. The pace of legislative developments, and lack of consultation, aroused suspicions about government motive — but also spurred on civil society organizations to closely scrutinize the NHRI, a practice which has persisted. Observers initially held out little hope for Suhakam. ${ }^{188}$ However, as documented in the next section, the fate of the NHRI has proven more complex (and more compelling) than many would have predicted. This is largely due to the astute activation of formal promotional powers in the face of governmental resistance to independent scrutiny.

\section{The impact of robust promotional powers on the Malaysian NHRI}

Promotional activities have been a centerpiece of Suhakam activities since it began operations in April 2000. Suhakam has made particularly good use of its explicit power to publish special reports based on public inquiries. In an early signal of autonomy, Suhakam issued a special report in mid-2001 on Freedom of Assembly, calling for the abolition of police permits at public rallies in the context of a draconian Internal Security Act (ISA). Prime Minister Mahathir strongly criticized the report for ignoring security concerns. Its review of the ISA was widely circulated within $\mathrm{NGO}$ and $\mathrm{UN}$ forums with some advocates calling it an "incredible report." 189

A series of public inquiries from 2006 to 2009 have impacted the media, with Suhakam documenting human rights abuses and making robust recommendations to the authorities. This included issues of deaths in custody, freedom of assembly, excessive force by police, unlawful arrest, and violations of indigenous rights by transnational corporations. ${ }^{190}$ Having established its credibility, Suhakam has also used the threat of public inquiries to spur public authorities such as the police into action, with commissioners stating that the court of public opinion is "more powerful than any court."191

Suhakam has also made inroads into activating its legislative advisory function. The Commission was consulted in the passing of the Anti-Trafficking in Persons Bill in May 2007. It was involved in a 2001 amendment to the Constitution that introduced gender into the list of discrimination prohibitions. However, it has been notably less successful in achieving ratification of international human rights treaties. ${ }^{192}$ Indicative of official resistance, when Suhakam organized a "closed-door discussion" on the ISA in 2008 with relevant government agencies, all the officials declined to attend. ${ }^{193}$

The NHRI has actively pursued its human rights promotion and education function, regularly organizing workshops and conducting road shows throughout the national territory to raise awareness on human rights and the role of Suhakam. ${ }^{194}$ Importantly, it has expanded its

\footnotetext{
188 Thio, supra note 185 , at 1275.

${ }^{189}$ Ken Setiawan, Promoting Human Rights: National Human Rights COMmissions in Indonesia AND MALAYSIA 158 (2013).

190 See SUHAKAM public inquiry reports, at http://www.suhakam.org.my/pusat-media/sumber/laporansiasatan-awam.

191 Thio, supra note 185 , at 1303.

192 As of September 2016, Malaysia has only ratified two treaties, the Convention on the Elimination of all Forms of Discrimination Against Women and the Convention on the Rights of the Child.

${ }^{193}$ SETIAWAN, supra note 191, at 160-61.

${ }^{194}$ Carolyn Evans, Human Rights Commissions and Religious Conflict in the Asia-Pacific Region, 53 THE INT'L \& COMP. L. Q. 713, 720 (2004).
} 
promotional activities beyond the civil-political to include social, economic, and cultural rights that fall outside its jurisdiction, not being in the Constitution or regarded as justiciable in Malaysia. Indeed, it has sought to redress what it views as an "imbalance," arguing "both sets of rights need to be treated with equal importance." 195 It has also sought to inculcate human rights norms among public officials through training programs.

In 2012, Suhakam launched its most audacious promotional campaign yet, undertaking its first national public inquiry into land rights of indigenous people. ${ }^{196}$ National public inquiries are non-judicial inquiries into systemic or widespread human rights abuses. As Meg Brodie notes, "all national inquiries seek to create change: to stop systemic or widespread abuse, and to encourage the internalization of human rights norms." ${ }^{\text {"197 }}$ In short, they are perhaps an NHRI's most powerful promotional instrument. Over the course of two years, Suhakam sought to "examine the root causes of the problems relating to native customary right to land and to recommend appropriate solutions to the problem." 198 A highly detailed report was published in 2013, receiving significant domestic and international coverage. ${ }^{199}$ The prime minister's cabinet announced in June 2015 the establishment of a Cabinet Committee to oversee implementation of recommendations stemming from the inquiry. ${ }^{200}$

Civil society observers and experts highlight the importance of formal promotional powers in understanding the positive impact of the Malaysian NHRI. At the same time, progress has been subject to government stonewalling, with the NHRI initially labeled a "toothless tiger" by some in the NGO community. ${ }^{201}$ Civil society observers give the NHRI a mixed score card through its first decade in operation. While it robustly intervened on issues of legal protections and the rule of law, it was more reticent to involve itself in investigating human rights violations in the context of political freedoms, ethnic conflict, and religious conflict. ${ }^{202}$ Relations between some human rights organizations and Suhakam have, at times, been characterized by hostility from both sides. ${ }^{203}$ However, other NGOs have acknowledged Suhakam "as a bridge between us and the establishment." 204

The variable success of the NHRI over time has also been significantly marked by the ebb and flow of highly committed leadership. Suhakam did defy expectations in the period immediately following its inception. In part, this can be attributed to the appointment of former Deputy Prime Minister Musa bin Hitam (1999-2002) as chair. Musa was Malaysia's special

\footnotetext{
195 Thio, supra note 185 , at 1310

${ }^{196}$ SUHAKAM, REP. OF THE NATIONAL INQUIRY INTO THE LAND RiGHTS OF INDIGENOUS PEOPLES (Apr. 2013), available at http://www.suhakam.org.my/pusat-media/sumber/laporan-siasatan-awam.

${ }^{197}$ Meg Brodie, Uncomfortable Truths: Protecting the Independence of National Human Rights Institutions to Inquire, 38 U.N.S.W. L.J. 1215, 1219 (2015).

198 See SUHAKAM, Suhakam to Conduct a National Inquiry into the Land Rights of Indigenous Peoples in Malaysia (May 13, 2011), available at http://nhri.ohchr.org/EN/Themes/BusinessHR/Business\%20Womens\%20and\%20Childrens\%20Rights/SUHAKAM $\% 20$ BI\%20FINAL.CD.pdf.

${ }^{199}$ Malaysia Must Protect Environment, Indigenous Rights as It Reduces Poverty - UN expert, UN NEWS CENTRE (Dec.18, 2013), at http://www.un.org/apps/news/story.asp?NewsID=46774\#.WP1Ktojysvg.

200 Loh Foon Fong, Cabinet Forms Committee on Indigenous Right, STAR (June 17, 2015), at http://www.thestar.com.my/news/nation/2015/06/17/cabinet-approves-indigenous-lands-rights.

${ }^{201}$ Elizabeth Wong, Release the ISA-6, NATIONAL HuMAN RightS SOCIETY (HAKAM) PrESS RelEASE (Apr. 10, 2003).

202 SETIAWAN, supra note 191, at 134.

${ }^{203} \mathrm{Id}$.

204 Thio, supra note 185, at 1336.
} 
envoy to the UN, leading the Malaysian delegation to the UN Commission on Human Rights from 1993 to 1998. Despite a record of robustly defending the government's rejection of the "western perception" of human rights, ${ }^{205}$ Musa emerged as a surprisingly vocal rights advocate, especially regarding abuses by security personnel. Motivated Suhakam commissioners have invoked their governing law to pursue impactful promotional activities. However, other commissioners have been content to do little or sought to ingratiate themselves "as a partner of the government." 206

Commission inquiries have rarely enjoyed the support of government officials, with relations characterized more by indifference and conflict. The Malaysian political elite has traditionally adopted a hostile stance toward international human rights norms, as indicated by a poor ratification record. Notwithstanding, in the words of one observer, "Suhakam certainly . . . launched headlong into its educational function and pride[d] itself on raising public awareness of human-rights issues." 207 This is significant. However, while Suhakam "has been given the freedom to conduct its activities" that "is also where it ends." 208

An audacious beginning inevitably provoked backlash. The first indication of government pushback came with the appointment of Abu Talib Othman as chair in 2002. A former attorney general with a problematic rule of law record, his appointment was greeted with dismay by the NGO community. ${ }^{209}$ In anticipation of Othman's arrival, one final act by the Commission had been to begin experimenting with its public inquiry power. Published in 2001, the first inquiry's highly critical finding of excessive use of force by police against peaceful demonstrators was widely publicized. ${ }^{210}$ The commissioners responsible for the inquiry did not have their terms renewed. ${ }^{211}$ Other outspoken commissioners were similarly removed. ${ }^{212}$ In a further effort to muzzle the NHRI, the majority government party blocked discussion of Suhakam's first annual report in parliament - a practice which persists to this day. ${ }^{213}$

Relations with civil society during this period became fraught with Suhakam reassigned to the jurisdiction of the Prime Minister's Department in 2004, raising doubts over its autonomy. ${ }^{214}$ However, by the end of the decade the political winds were again blowing against the ruling National Front coalition. In 2008, the National Front retained power but suffered its biggest loss in electoral history. Observers put the result down to growing popular discontent over the failure of institutions like Suhakam to safeguard human rights and democracy. ${ }^{215}$

${ }^{205}$ Kieran Cooke, Asians Challenge West on Human Rights, FinANCIAL TiMES (June 11, 1993).

206 SETIAWAN, supra note 191, at 139.

207 Thio, supra note 185 , at 1299.

208 SETIAWAN, supra note 191, at 139.

${ }^{209}$ Leong Kar Yen, Abu Talibs Appointment Will Render Suhakam Meaningless: Aliran, MALAYSIAKINI (Apr. 15, 2002), at https://www.malaysiakini.com/news/11107.

${ }^{210}$ K. Kabilan, Suhakam Slams Police for Rights Abuses in Kesas Highway Assembly, MaLAYSIAKINI (Aug. 20 2001), at https://www.malaysiakini.com/news/4387.

${ }^{211}$ Thio, supra note 185 , at 1295.

212 The ASian NGOs Network On NAT'L Human Rights Inst., 2008 ANNI RePORT ON THE PERFORMANCE AND ESTABLISHMENT OF NATIONAL HUMAN RIGHTS INSTITUTIONS IN ASIA, 96 (2008) (on file with author).

213 THe ASIAN NGOS NETWORK ON NAT’L HumAn Rights InST., 2009 ANNI REPORT ON THE PERFORMANCE AND ESTABLISHMENT OF NATIONAL HUMAN RIGHTS INSTITUTIONS IN ASIA, 100 (2009), available at http://protectionline.org/files/2012/08/Report-on-the-Performance-and-Establishment-of-National-Human-RightsInstitutions-in-Asia-2009.pdf [hereinafter ANNI REPORT 2009].

${ }^{214} I d$. at 94.

${ }^{215} I d$. at 90. 
Notwithstanding its subdued public presence, the Commission began to flex its promotional muscles again as the 2008 elections approached. ${ }^{216}$

The decisive break for the NHRI came in 2008 with its reaccreditation at the UN up for renewal. This review served as a powerful focal point for mobilization by international and domestic supporters of an office that had raised expectations through effective promotional activities. Caught between domestic pressures for reform, a well-orchestrated campaign by Suhakam commissioners, alongside supportive local NGOs, and international calls for Paris Principles compliance, the Malaysian government eventually relented, legislating for significant changes to the NHRI's appointment procedures and extension of commissioners' term limits to three years. ${ }^{217}$ A new intake of commissioners in 2009 also gave cause for optimism, with all appointees coming from NGO backgrounds with the exception of the Chair, Tan Sri Hasmy Agam. Formally the government's Permanent Representative to the UN in New York, Hasmy nevertheless quickly demonstrated his commitment to independence and, importantly, began to deliver results. To many observers' surprise, Hasmy proved to be a committed and effective NHRI leader; according to a leading NHRI practitioner, "once appointed he took the role he was supposed to fulfill very seriously."218

Astute use of promotional powers by the Commission post-2009 within a more benign political climate has produced important feedback loops, and marked the rebirth of an effective Suhakam. In 2011, a coalition of NGOs organized a mass rally calling for electoral reform, dubbed "Bersih 2.0." Leading up to the rally, Suhakam issued robust statements in support of freedom of assembly and criticized the government's ban. In response to allegations of police violence, the Commission opened a public inquiry and, in a novel move, the Royal Malaysian Police (RMP) pledged their full cooperation. ${ }^{219}$ In response to allegations of violations in a repeat rally in 2012, dubbed "Bersih 3.0," the Commission opened another public inquiry. The final report strongly criticized the police, but also called upon demonstrators to act lawfully. ${ }^{220}$ Notably, during the "Bersih 4.0" of 2015, although once again declared illegal, the RMP conducted themselves peaceably on this occasion. ${ }^{221}$ As one NGO observer notes:

\footnotetext{
216 Thio, supra note 185 , at 1327.

217 Kieren Fitzpatrick \& Catherine Renshaw, National Human Rights Institutions in the Asia Pacific Region: Change Agents Under Conditions of Uncertainty, in Human Rights, StATE Compliance, AND Social CHANGE, supra note 13 , at 150, 163-64.

218 Skype Interview with Rosslyn Noonan, former Chief Commissioner, New Zealand Human Rights Commission (July 24, 2015).

219 The Asian NGOs Network on National Human Rights Inst., 2012 ANNI Report ON THE

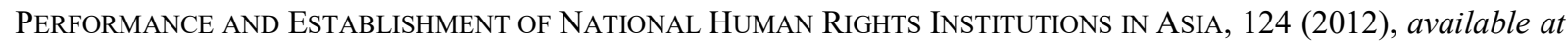
http://www.forum-asia.org/uploads/books/2012/nov/05033_ANNI\%202012.pdf.

${ }^{220}$ See SUHAKAM, SUHAKAM's FINDINGS FROM THE PUBLIC INQUIRY INTO THE INCIDENTS DURING AND AFTER THE PUBliC ASSEMBLY OF 28 APRIL 2012 (Apr. 17, 2013), available at http://www.suhakam.org.my/wpcontent/uploads/2013/11/SUHAKAM-PRESS-STATEMENT_SUHAKAMS-FINDINGS-FROM-THE-PUBLICINQUIRY-INTO-THE-INCIDENTS-DURING-AND-AFTER-THE-PUBLIC-ASSEMBLY-OF-28-APRIL2013_Released-on-17-April-2013.pdf.

${ }^{22} 1$ SUARAM, Human Rights ReP. 2015 Overview: Civil AND Political Rights 3 (2015), available at http://www.suaram.net/wordpress/wp-content/uploads/2015/12/SUARAM-HR-OVERVIEW-2015-combinedver1.pdf.
} 
These public inquiries [into the Bersih campaign] mattered because it engaged with an issue on a national scale. . . . I commend Suhakam for responding in a very timely manner to the issues, the critical issues which are gripping the country. ${ }^{222}$

Improved standing in international and domestic non-governmental circles appears to have also been noticed by government, with the minister for parliamentary affairs accepting "in principle" that Suhakam's annual report should be discussed in plenary. ${ }^{223}$ The attorney general's chamber invited the Commission to advise on draft legislation, including the 2011 Public Assembly Bill and the Security Offices (Special Measures) Act (SOSMA). ${ }^{24}$ ISA was finally repealed in 2012, replaced by SOSMA. Suhakam has cautiously welcomed this development. ${ }^{225}$ The Commission has also been instrumental in getting the government to withdraw reservations from the Convention on the Rights of the Child and Convention on the Elimination of all Forms of Discrimination Against Women and in 2010 issued its strongest statements yet on Malaysia's poor ratification record:

Personally, I've always felt it's embarrassing that Malaysia has yet to ratify these conventions, especially the Convention Against Torture. We cannot condone torture. It's a long-haul fight. We will continue to engage with the government. I'll be happy if the government is willing to come on board. ${ }^{226}$

However, once again, Suhakam confronts a hostile government in a deteriorating rights context under the administration of Prime Minister Najib Razak (2009-present). ${ }^{227}$ Slippage in civil and political protections is apparent with the passage of the Prevention of Terrorism Act (2015). Suhakam has not shied away from confrontation. 228 In late 2015, the government announced that Suhakam's budget would be cut by 50 percent. ${ }^{229}$ Many observers concur that this likely the government sending the message "don't bite the hand that feeds you." 230 However,

222 Skype Interview with Joses Kwan, East Asia Programme Associate, Forum-Asia (Sept. 23, 2015).

${ }^{223} \mathrm{Id}$.

${ }^{224}$ ANNI REPORT 2009, supra note 215, at 125.

225 Anisah Shukry, Suhakam Joins Call for Review of ISA Replacement Law, MALAYSIAN INSIDER (Apr. 16, 2012), at https://blog.limkitsiang.com/2012/04/16/suhakam-joins-call-for-review-of-isa-replacement-law.

${ }^{226}$ Gan Pei Ling, Suhakam Chief: "We're an Independent Entity," NuT GRAPH (Aug. 30, 2010), at http://www.thenutgraph.com/suhakam-chief-\%E2\%80\%9Cwere-an-independent-entity\%E2\%80\%9D （quoting Suhakam Chief, Tan Sri Hasmy Agam).

${ }^{227}$ SUARAM, HuMAN RightS REPORT 2015 OvERVIEW: Civil AND POLITICAL Rights (2015), available at http://www.suaram.net/wordpress/wp-content/uploads/2015/12/SUARAM-HR-OVERVIEW-2015-combinedver1.pdf.

${ }^{228}$ Suhakam Rubbishes 'Narrow Approach' to Interpret, Understand Human Rights, MALAYSIAN INSIDER (Aug. 20, 2015).

229 Suhakam Seeks Answers from Putrajaya After Drastic Budget Cuts, MALAYSIAN InSIDER (Nov. 10, 2015), available at https://sg.news.yahoo.com/suhakam-seeks-answers-putrajaya-drastic-050232095.html.

${ }^{230}$ Khoo Ying Hooi, Suhakam Budget Cuts, a Case of 'Don't Bite the Hand that Feeds You'?, MALAYSIAN INSIDER (Dec. 14, 2015), available at http://hakam.org.my/wp/index.php/2015/12/14/suhakam-budget-cuts-a-caseof-dont-bite-the-hand-that-feeds-you-khoo-ying-hooi. 
many actors, both domestic and international, ${ }^{231}$ have rallied to Suhakam's defense and mounting pressure may have had some effect. ${ }^{232}$ As the director of a prominent Malaysian NGO states:

After 15 years of struggle, Suhakam has obtained some degree of recognition by Malaysians. While their success was not without flaws, the impact they have in the human rights discourse in Malaysia cannot be dismissed easily. ${ }^{233}$

Our case study illustrates that the qualified successes of the Malaysian NHRI have been achieved despite adverse background conditions, and despite circumscribed independence safeguards. Ambitious NHRI commissioners have made use of extensive promotional powers to introduce diverse human rights issues onto the national agenda, forcing the legislature and the executive to respond, empowering like-minded civil society and international actors, and on occasion, when openings in the governing regime have appeared, shaping important legislative initiatives. At the same time, the NHRI has not consistently been able to translate extensive publicity into concrete actions, and has on occasion, and appropriately in our view, been recommended for downgrade to " $\mathrm{B}$ " within the peer review process.

\section{F. Philippine Commission on Human Rights}

We next turn to the Philippines to create a counterfactual, where the NHRI lacks extensive promotional powers, because it was established shortly before the Paris Principles popularized these powers. Even though the Philippine NHRI was set up under no less hospitable circumstances than in Malaysia, and had additional independence safeguards, it was unable to mobilize national opinion as effectively as the Malaysian NHRI. This is, in part, because of its formal structure; when an entrepreneurial NHRI head experimented with expanding promotional activities, the Philippine Supreme Court shut down this strategy, by ruling that the NHRI had exceeded its jurisdiction. Philippine NHRI leaders turned their energies to other strategiesabove all, helping the legal system with human rights investigations-where the NHRI has some limited, but clearly established institutional competencies. This alternative pathway was unsuccessful, however.

\section{Explaining the limited promotional powers of the Philippine NHRI}

The Philippine Commission on Human Rights (CHR) was established in May 1987, in the wake of the overthrow of the Marcos dictatorship (1972-86). It embodies the strong emphasis placed in the new 1987 constitution on civil liberties. ${ }^{234}$ The design of the CHR is oriented toward legal protection, vested with the power to cite individuals for contempt of court, provide

${ }^{231}$ Ida Lim, Global Embarrassment for Malaysia if Suhakam Loses 'Grade A' Status, Chief Warns, MALAY MAIL (Apr. 15, 2015), at http://www.themalaymailonline.com/malaysia/article/global-embarrassment-for-malaysiaif-suhakam-loses-grade-a-status-chief-war.

232 Suhakam: Putrajaya Has Agreed to Review our Budget Cut, MALAY MAIL (Nov. 16, 2015), at

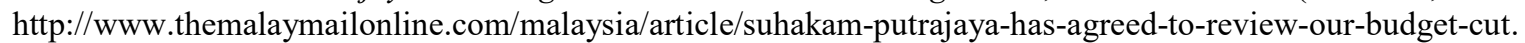

233 Elizabeth Zachariah, Suhakam Seeks Answers from Putrajaya After Drastic Budget Cuts, MALAYSIAN INSIDER (Nov. 10, 2015), available at http://hakam.org.my/wp/index.php/2015/11/10/suhakam-seeks-answers-fromputrajaya-after-drastic-budget-cut (citing Sevan Doraisamy, Suaram Executive Director).

${ }^{234}$ CONST. (1987), Art. XIII, sec. 18 (Phil.). 
legal aid to individuals, access all places of detention, provide compensation to victims, and grant immunity from prosecution. ${ }^{235}$

On the promotive side, the CHR lacks explicit powers to produce reports or advise on legislation. It is directed to "[e]stablish a continuing program of research, education, and information to enhance respect for the primacy of human rights" and further promotional prerogatives can be inferred from a mandate to "[r]ecommend to the Congress effective measures to promote human rights . . ." and to "[m]onitor the Philippine Government's compliance with international treaty obligations on human rights." ${ }^{\text {"236 }}$ During the 1986 debate on the CHR law, Commissioner Rosario Braid expressed concern at the lack of specificity on CHR promotional powers. ${ }^{237}$ However, the bill sponsors argued that reference to "a continuing program of education" was sufficient. ${ }^{238}$ A legal control mandate is further emphasized in the requirement that a majority of commissioners be members of the bar. ${ }^{239}$

A combination of domestic and international drivers contributed to the government's decision to establish the first NHRI in Southeast Asia. The CHR was a direct response to what happened in the Marcos era, as stated by one of the bill's sponsors in the 1986 congressional deliberations: "The commission has a very specific function which is the protection of civil and political rights. Due to the experience of fourteen years of martial rule, we want to . . provide this very specific body with the function to ensure the safeguarding of these rights." 240 Reflecting domestic demand, in its first year of operation, the Presidential Commission on Human Rights (PCHR) had already begun receiving complaints, including seven hundred cases of alleged human rights violations filed by the leading NGO, Task Force Detainees of the Philippines (TFDP)..$^{241}$

In contrast to the Malaysian experience, established six years prior to UN endorsement of the Paris Principles, international influence on CHR design is marginal. Deliberations were influenced by a 1984 UN resolution, but this only provides a blanket recommendation to establish or strengthen such institutions. ${ }^{242}$ One of the first official acts of President Corazon C. Aquino (1987-1992) was to establish the PCHR in 1986, succeeded by the CHR a year later. Reflecting the personal commitment of the executive to the CHR, legislative drafters were highly expert, chaired by a Supreme Court Justice. However, lacking international guidelines and informed by their legal formalist training, the resulting CHR is an awkward fusion of omitted

${ }^{235} I d$.

${ }^{236} \mathrm{Id}$.

${ }^{237}$ Commissioner Rosario Braid, quoted in Deliberations of the Constitutional Committee, at 78-79 (Aug. 26, 1986), available at http://www.ombudsman.gov.ph/UNDP4/wp-content/uploads/2013/03/HR-Legislative-AgendaResource-book-1.pdf.

${ }^{238}$ Commissioner Abraham F. Sarmiento, quoted in Deliberations of the Constitutional Committee, at 79 (Aug. 26, 1986), available at http://www.ombudsman.gov.ph/UNDP4/wp-content/uploads/2013/03/HR-LegislativeAgenda-Resource-book-1.pdf.

${ }^{239}$ CONST. (1987), Art. XIII, sec. 17 (Phil.).

${ }^{240}$ Commissioner Edmundo O. Garcia, quoted in Deliberations of the Constitutional Committee, at 51 (Aug. 26, 1986), available at http://www.ombudsman.gov.ph/UNDP4/wp-content/uploads/2013/03/HR-Legislative-AgendaResource-book-1.pdf.

${ }^{241}$ Jefferson Plantilla, Elusive Promise: Transitional Justice in the Philippines, in HuMAN Rights DialoguE 1.8 (SPRING 1997): “Transitional JustiCE IN EAST ASIA AND ITS IMPACT ON HuMAN Rights," (Carnegie Council for Ethics in International Affairs, 1997), available https://www.carnegiecouncil.org/publications/archive/dialogue/1_08/articles/553.html/:pf_printable.

242 Abraham F. SARMiento, Journey of A RetiRed Supreme CourT Justice 24 (2008) [hereinafter SARMIENTO 2008]. 
promotional powers, investigative prerogatives, and no enforcement authority. As the next section examines, the prosecutorial orientation of the CHR, while not precluding promotional activities, has led to pushback to alleged agency overreach and powerfully shaped the working practices of the organization.

\section{The impact of limited promotional powers on the Philippine NHRI}

A formal orientation toward a prosecution function has had a powerful impact on the activities of the Philippine NHRI. Against a backdrop of rampant human rights violations and serious failings in the Philippine judicial system, it is unsurprising that the CHR would orientate itself in this direction, neglecting its limited promotional faculties. Initially, the Department of Justice regularly deputized CHR lawyers to assist in the prosecution of human rights cases. CHR personnel dutifully filed 1,509 cases of alleged human rights violations before the courts between 1987 and 1990. However, the CHR faced a formidable obstacle in the form of rampant judicial misconduct. Only eleven cases resulted in sanctions against the perpetrators. ${ }^{243}$ After three years of operation, the CHR could "boast few real results." 244

Compared to the Malaysian NHRI, the CHR's promotional remit lacks specificity and omits key powers. As a result, the Philippine office initially made little use of its promotional authority. It was conspicuously silent on high profile human rights violations, including the notorious 1987 Lupao Massacre. The CHR claimed that it could not investigate such abuses "in an environment of war." 245 The CHR also became bogged down in legal petitions, including private disputes over property and theft, quickly draining the institution of strategic direction. Observers lamented this strategic decision, especially when "[p]rivate persons are subject anyway to existing laws on prosecution of criminal offenders." 246

Civil society observers became exasperated with an NHRI lacking enforcement authority and apparently unwilling to experiment with its limited promotional remit. The Commission had lost precious time to establish its credentials:

Although the CHR may be able to regroup its forces after several early political snafus, precious time has been lost. The Commission has few recommendations for prosecution and even fewer convictions to show for hundreds of complaints received. . . . Acting effectively, the CHR could have a tremendous impact in the Philippines today by exposing perpetrators of human rights abuses and, thereby, deterring future abuses. ${ }^{247}$

Formal limitations on human rights promotion was compounded by poor CHR leadership. The first Chair, Mary Concepcion Bautista (1988-1992), a criminal litigator by training, endorsed a legalistic paradigm in CHR operations. Bautista also quickly lost credibility. In response to a critical Amnesty International report, Bautista falsely claimed that "[t]here are no political prisoners in the Philippines because the Aquino government does not tolerate human

243 Belinda Aquino, The Human Rights Debacle in the Philippines, in IMPUNITY AND HuMAN RIGHTS IN InTERNATIONAL LAW AND PRACTICE 231-42 (Naomi Roht-Arriaza ed., 1995).

${ }^{244}$ Barbara A. Frey, Commission on Human Rights: Advocate or Apologist, in THE PHILIPPINES: A HUMAN RigHTS SCRAPBOOK 25 (Minnesota Lawyers International Human Rights Committee, 1989).

245 PhilipPines: A COUNTRY STUdy 231-32 (Ronald E. Dolan ed., 1991).

246 SARMIENTO, supra note 242, at 29.

${ }^{247}$ Frey, supra note 246, at 28-29. 
rights violations." ${ }^{248}$ In reality, violations, and especially forced disappearances, had markedly increased compared to $1987 .{ }^{249}$ Such problematic conduct did not go unnoticed. ${ }^{250}$

Legal formalism among CHR professionals also hampered the NHRI's potential effectiveness. The vast majority of personnel recruited by Bautista entered from the legal profession, establishing a particular community of practice. Many CHR lawyers were illdisposed to conduct investigations into human rights crimes. ${ }^{251}$ As Abraham Sarmiento observes, "[i]n those exceptional cases that the CHR sets out to the fields the CHR has been noted for a lack of 'vigor' in finding out the truth." ${ }^{252}$ Former Commissioner Paulynn Sicam recalls being the only non-lawyer in the CHR when she joined the CHR in 1991: "They gave me information and education. "You are not a lawyer, so we will give you a non-lawyer's job. They looked down on me because I wasn't a lawyer." 253 In short, a formal mandate that emphasized investigation and deemphasized promotion shaped early hiring in favor of lawyers.

Marginal to CHR strategic priorities, ironically the new office for public information and education "turned out to be the most active branch of the commission." 254 This area of activity was even met with some receptiveness by the authorities, with CHR police human rights training becoming mandatory in 1995. A Memorandum of Understanding to establish an Inter-Agency Chamber of Human Rights was signed in 1995 between the Department of Justice, the Department of National Defence, and the Department of the Interior. Human Rights Action Centers were established in around 42,000 villages nationwide. Through creative expansion of a limited education mandate, the CHR had "found a way to actually overcome those limitations ... . contained formally in our charter." ${ }^{255}$ This activity was so successful that the Commission even received the 1994 UNESCO Prize for the Teaching of Human Rights. ${ }^{256}$

However, expanding promotional activity confronted serious challenges. Some observers questioned whether training of security personnel was the best use of resources, when it could be used for "mobilizing training organisations such as the academe and NGOs; and monitoring, advocacy and public reporting . . .."257 Alleged violations by the police remained high throughout this period. ${ }^{258}$

While the NHRI's charter included one promotional function - education-it lacked two other powers often found in other NHRI charters: the power to advise on legislation, and to produce annual reports. In terms of advising on legislation, the office had no formal jurisdiction and there is little evidence of CHR impact on human rights law during this period. The death

\footnotetext{
${ }^{248}$ LeOnARd Davis, ReVolutionary Struggle in the PhilipPines 178 (1988).

249 Gerard Clarke, The Politics of NGOs in South-East Asia: Participation and Protest in the PHILIPPINES 185 (1998).

250 The Carter Ctr., Investigating Abuses and Introducing Safeguards in the Democratization Process 76-77 (July 1992), available at https://www.cartercenter.org/documents/1209.pdf.

${ }^{251}$ Frey, supra note 246. at 27.

252 SARMIENTO 2008, supra note 236, at 32.

253 Skype interview with Paulynn Sicam, former Commissioner (1991-1994), Commission on Human Rights (June 27, 2016).

${ }^{254} I d$.

${ }^{255}$ Interview with Gwen Pimentel Gana, Commissioner, Commission on Human Rights (June 30, 2016).

2561994 UNESCO Prize for the Teaching of Human Rights, awarded to the CHR and José Zalaquett Daher, Paris (Jan. 26, 1995).

257 Center for Public Resource Management, Inc. (CPRM), Institutional Review \& Performance ASSESSMENT: COMMISSION ON HUMAN RIGHTS 37 (2003).

${ }^{258}$ U.S. DePARTMENT OF STATE, 2000 COUNTRY REPORTS ON HuMAN Rights PRACTICES, PhilipPINES (2001), available at $\mathrm{http}: / / \mathrm{www} . \mathrm{state} . g o v / \mathrm{j} / \mathrm{drl} / \mathrm{rls} / \mathrm{hrrpt} / 2000 / \mathrm{eap} / 764 . \mathrm{htm}$.
} 
penalty was reinstated in 1993 and progressively expanded to a range of offenses until a moratorium was declared in 2000. The government took few effective steps to reform the police, military, or judicial system. ${ }^{259}$ The CHR did develop a practice of occasionally preparing reports despite being under no formal obligation. However, reports appeared erratically and were not published for public scrutiny, a practice which has persisted. ${ }^{260}$

The CHR's lacklustre performance was doubly frustrating for NGO observers given that the Aquino administration offered a window of opportunity for human rights advocacy with implicit governmental support. This window would be firmly shut with the arrival of Aquino's successor, President Fidel Ramos (1992-1998). A former chief-of-staff of the armed forces, Ramos was himself accused of abuses during the period of martial law under Marcos. Although civil and political rights violations decreased slightly under Ramos, violations of vulnerable groups surged. ${ }^{261}$

However, as government support for human rights faded, the CHR was about to dramatically rediscover its mission under new leadership. A former Ambassador to the United Nations and a recognized "human rights advocate,"262 Sedfrey Ordoñez (1992-1995) became CHR chairperson in 1992 following the sudden death of Bautista. He brought with him a deep understanding of the internal machinery of government. Change in direction was evident early on. With political prisoners once again a hot button issue in 1993, Ramos's administration erroneously credited the CHR with asserting that "there have been no new cases of political detention since July 1992 . . ." In contrast to his predecessor, Ordoñez was quick to repudiate the official statement and confirm the statistics of the campaigning NGO, the TFDP. ${ }^{263}$ Nevertheless, relations with Ramos also likely involved some complicated political footwork, with Ordoñez publicly endorsing the president's record on other occasions. ${ }^{264}$ Under Ordoñez, the CHR issued a series of hard-hitting special reports into systemic violations on the basis of a wide range of human rights investigations. ${ }^{265}$ In 1994, Ordoñez announced that "the commission will intensify its human rights education campaign" despite budget limitations. ${ }^{266} \mathrm{He}$ also used his connections to solicit the cooperation of allies within the state. ${ }^{267}$

However, the CHR's formal limitations would prove to be the undoing of this short-lived experiment. Just as Ordoñez was expanding the Commission's promotional mandate, the Supreme Court intervened to clip his wings. In January 1994, the Court ruled that the CHR's founding law limited the body to investigating civil and political rights only. ${ }^{268}$ Dispute centered

${ }^{259}$ U.S. Department of State, 1997 Country Reports on Human Rights Practices, Philippines (1998).

${ }^{260}$ Interview with Gwen Pimentel Gana, supra note 257 (GPG: "You don't need to be allowed, but there's no formal . . . requirement to submit a report." TP: "Could I get the annual reports?" GPG: "I'm not sure. . . Maybe we have a summary, but not annual reports."). See also CPRM, supra note 259, at 39.

${ }^{261}$ Lalaine Sadiwa, Philippines, in Human Rights In DeVEloping CounTRIES: YeArboOK 1995, at 298 (Peter Baehr, Hilde Hey, Jacqueline Smith \& Theresa Swineheart eds., 1995).

262 SARMIENTO 2008, supra note 244, at 39.

${ }^{263}$ CLARKE, supra note 251, at 187.

${ }^{264}$ See Gov't Commission, NGO Differ in Appraisal of Ramos Rights Record, UCANEws (Aug. 25, 1993), at http://www.ucanews.com/story-archive/?post_name=/1993/08/25/govt-commission-ngo-differ-in-appraisal-oframos-rights-record\&post_id=43873.

${ }^{265}$ See Government Commission Reports Children's Rights Widely Violated, UCANEWs (July 2, 1993).

${ }^{266}$ Bleak Prospects for Human Rights Progress Seen at Present, UCANEWS (Jan. 18, 1994), at http://www.ucanews.com/story-archive/?post_name=/1994/01/18/bleak-prospects-for-human-rights-progress-seenat-present\&post_id $=44600$.

${ }^{267}$ Skype Interview with Paulynn Sicam, supra note 255.

${ }^{268}$ See Simon Jr. v. CHR, G.R. No. 100150 (S.C., Jan. 5, 1994) (Phil.). 
on the deliberations of the constitutional drafters in 1986, with the CHR claiming that "it was not the intention of the (Constitutional) Commission to create only a paper tiger limited only to civil and political rights." However, the Supreme Court disagreed, noting that "it is readily apparent that the delegates envisioned a Commission on Human Rights that would focus its attention to the more severe cases of human rights violations." 269 The lone dissenting opinion of Justice Teodoro Padilla argued that, regardless, "the CHR should be given a wide latitude to look into and investigate situations which may (or may not ultimately) involve human rights violations."270

As a parting shot, in late 1995, Ordoñez issued Resolution No. A95-069 stating CHR operational priorities as: "investigative monitoring of incidents and/or conditions obtaining in the country which are violative of concerns in both areas of civil and political rights and economic, social and cultural rights [ESCR]." However, speaking in 2008, then CHR Chairperson Leila de Lima, laments how "[the CHR's] powers in relation to ESCR in general . . . have been considerably curtailed by jurisprudence." She goes on, "we are unfazed by the Simon decision, we intend to pursue the issue and challenge this again in the courts." ${ }^{271}$ A proposed new legislative charter for the CHR "would elaborate and make [the ESCR mandate] more specific . . . so that there are no more arguments on the matter." ${ }^{272}$ Reflecting on this episode, former Commissioner Sicam recalls: "We always wanted to be bigger than we were, because . . . people came to us with all sorts of cases. How do you send people away who look at you as a court, well not a court, but as an office of last resort?"273

Ordoñez's failed experiment set in motion unfortunate feedback loops, with the CHR reverting to a strong emphasis on legal protection activities. In 2002, an estimated 63.5 percent of the CHR's budget was allocated to such activities, with only 8.3 percent dedicated to "research, information and other human rights promotion activities." 274 Persistent concerns have surrounded investigation activities which threaten to jeopardize the independence of the Commission, with the focus falling on the violation itself, as opposed to the conduct of the enforcement agency. ${ }^{275}$

As with the Malaysian case, NHRI leadership has continued to be highly consequential in shaping the fortunes of the office. Ordoñez was not reappointed in 1995. Under the leadership of Aurora Navarette-Reciña (1996-2002) and Purification C. Valera Quisumbing (2002-2008), the profile of the CHR plummeted. Navarette-Reciña, a judge and criminal litigator by training, was widely viewed as a "disastrous appointment." 276 Against a backdrop of massive human rights violations during the administration of President Gloria Macapagal Arroyo (2001-2010), ${ }^{277}$ the CHR once again disappeared from view. ${ }^{278}$ The fragile gains made under Ordoñez unravelled, with interagency cooperation breaking down and the CHR subject to severe budget cuts in

\footnotetext{
${ }^{269} I d$.

${ }^{270}$ Padilla, J., dissenting in Simon Jr v. CHR, supra note 270.

${ }^{271}$ Leila de Lima, remarks delivered at The CHR on the Occasion of the Right to Food Forum (Oct. 1-3, 2008).

${ }^{272}$ Interview with Gwen Pimentel Gana, supra note 257.

${ }^{273}$ Skype Interview with Paulynn Sicam, supra note 255.

${ }^{274}$ CPRM, supra note 259 , at 35.

${ }^{275} \mathrm{Id}$.

${ }^{276}$ Skype Interview with Paulynn Sicam, supra note 255.

${ }^{277}$ ANNI REPort 2009, supra note 215, at 161-64..

${ }^{278}$ CPRM, supra note 257 , at 35.
} 
1997.279 No major CHR educational achievements are reported during the period 1997 to $2007 .^{280}$

The appointment of a new CHR Chairperson in 2008 was met with disappointment by human rights NGOs. ${ }^{281}$ However, President Arroyo quickly lived to regret this decision. ${ }^{282} \mathrm{~A}$ former election lawyer with no human rights experience, Leila de Lima inspired little confidence. Under de Lima's leadership the CHR once taunted as a "toothless tiger," began to roar, "transformed into a high-profile watchdog. ${ }^{283}$ De Lima proved to be a formidable public advocate who quickly had the president "on the ropes." 284 Her leadership strategy represented a significant departure for the CHR, reflecting on her term as chair:

Some have called me a controversial public figure. I will not and cannot deny. Back when I was the Chairperson of the Commission of Human Rights, public advocacy was our most effective and important weapon against the then prevailing culture of silence and impunity ...."285

With de Lima's actions described by observers as "courageous and impressive, probably unprecedented," 286 the CHR took up the mantle left by Ordoñez and began to actively pursue a promotional mandate. Indicative of CHR impact, one of the first acts of President Benigno Aquino III (2010-2016) was the signing of the Anti-Torture Act into law, accompanied by the new CHR Chair, Loretta Rosales (2010-2015). However, again, official support for human rights rapidly diminished. The CHR now faces its biggest test amidst the human rights crisis engulfing the country under President Rodrigo Duterte (2016-). Isolated within the political establishment, the CHR has been directly targeted by Duterte. ${ }^{287}$ The CHR budget was subsequently slashed by 40 percent. ${ }^{288}$ In December 2016, the CHR bravely launched an investigation into "claims by President Rodrigo Duterte that he personally killed drug suspects while mayor in Davao," making international headlines. ${ }^{289}$

The qualified failure of the Philippine NHRI has been strongly informed by the relative lack of formal promotional powers. A formal legalist orientation set in motion a path trajectory

${ }^{279}$ Li-ann Thio, Implementing Human Rights in ASEAN Countries: Promises to Keep and Miles to Go Before I Sleep, 2 YAle HuM. RTS. \& DEV. L.J. 1, 71 (1999).

${ }^{280}$ Ana Elzy E. Ofreneo, Director, Commission on Human Rights, Policies on Human Rights Education in the Philippines (2013), available at https://www.ihrec.ie/download/pdf/plenary_theme_1elzy_ofreneo.pdf.

${ }^{281}$ Forum-Asia/PAHRA, Dissatisfaction with the CHR Chair Appointment (May 15, 2008).

282 Skype Interview with Paulynn Sicam, supra note 255.

${ }^{283}$ Howie Severino, Leila de Lima: GMA News. TV's Public Servant of the Year, GMANEwS.TV (Dec. 31, 2009, 13:47 PHT), at http://www.gmanetwork.com/news/story/180559/news/specialreports/leila-de-lima-gmanewstv-s-public-servant-of-the-year.

${ }^{284}$ Skype Interview with Paulynn Sicam, supra note 255.

${ }^{285}$ Elfren S. Cruz, Leila de Lima: Justice Without Fear or Favor, PhilstAR GlobAl (Aug. 30, 2015, 12:00 PHT), at www.philstar.com/opinion/2015/08/30/1493911/leila-de-lima-justice-without-fear-or-favor.

286 Carlos Conde, Is Leila de Lima for Real?, GMA NEWS (May 28, 2008, 21:13 PHT), at http://www.gmanetwork.com/news/story/97855/opinion/is-leila-de-lima-for-real.

${ }^{287}$ Karlos Manlupig \& Tarra Quismundo, Duterte Calls HR Chair Idiot, INQUIRER (May 27, 2016, 3:27 PHT), at http://newsinfo.inquirer.net/787771/duterte-calls-chr-chair-idiot.

${ }^{288}$ Christian V. Esguerra, CHR Claims Budget Dep't Nearly Halved its Funding Request, ABS-CBN (Aug. 25, 2016, 19:09 PHT), at http://news.abs-cbn.com/news/08/25/16/chr-claims-budget-dept-nearly-halved-its-fundingrequest.

289 Philippines Leader Duterte Faces Investigation over Killings Claim, BBC (Dec. 22, 2016), at http://www.bbc.com/news/world-asia-38403977. 
which marginalized the promotive function of the NHRI, which would have likely yielded more success. Ambiguity over a limited set of promotive powers has been compounded by poor leadership and a legalistic culture of practice. This case affirms the importance of certain types of promotional functions for securing institutionalization. In their absence, the CHR has failed to have the sustained national impact observed in the Malaysian case. However, similar to the Malaysia experience, individual leadership can make a difference. Individual CHR heads have, at different times, deviated from the norm and compelled powerful actors to respond to egregious human rights violations. Nevertheless, formal authority in key promotional areas provides an important safeguard for sustaining such efforts. In this case, formal authorization would have precluded the damaging Supreme Court challenge to CHR jurisdiction.

\section{CONCLUSION}

NHRIs have emerged within the international human rights system as a possible missing link between ambitious international standards and highly uneven human rights practices on the ground. Propelled by UN promotional efforts and, more recently, novel treaty compliance arrangements, these national monitoring structures represent a transformation in the human rights landscape. NHRIs can now be found in over 120 countries, in every continent and sub-region of the world, and are common in both democratic and authoritarian regimes. Building on earlier work demonstrating the surprising diffusion and influence of the non-binding UN-endorsed 1991 Paris Principles on NHRI institutional design, ${ }^{290}$ this article has examined when and why NHRIs are effective. The stakes are high, above all, for those who have suffered rights violations at the hands of government or security forces, yet find that they have little recourse to justice.

An important prior quantitative study offers a measure of optimism; it concludes that countries that set up NHRIs perform better on critical physical integrity measures, such as freedom from torture, extrajudicial killing, political imprisonment, and disappearance, than countries that lack NHRIs. ${ }^{291}$ However, qualitative case studies reveal surprising variation among NHRIs, praising some for robust, even heroic, protection efforts, while condemning other bodies as sham institutions. ${ }^{292}$

This study is the first systematic assessment of the determinants of NHRI success or failure around the world. We collected fine-grained quantitative data on twenty-two formal institutional design features of all NHRIs around the world, focusing on four critical dimensions: independence safeguards, investigatory powers, promotion functions, and inclusiveness. We assessed NHRI effectiveness using both NHRI grades and our own original expert survey data. We combined this quantitative research with in-depth case studies of carefully matched country pairs.

Broadly, our study demonstrates that formal institutional safeguards influence human rights outcomes, in part because formal institutional design remains relatively stable over time. Whereas governments can often resist NHRI advocacy by pulling on other levers - notably by manipulating personnel appointments and cutting budgets - they find it harder to change formal safeguards. In turn, formal safeguards structure the initial hiring and priorities of NHRIs, shape

${ }^{290}$ Linos \& Pegram, Architects of Their Own Making, supra note 8, at 1110, 1121; Linos \& Pegram, The Language of Compromise, supra note 7, at 589, 601-02.

291 See Cole \& Ramirez, supra note 17.

292 See supra text accompanying notes 29-31. 
modes of resistance, and contribute to the development of positive or negative feedback loops over time.

Our study suggests that one institutional safeguard above all, the power to initiate, execute, and complete investigations on receipt of complaints, stands out as particularly important in enabling NHRI effectiveness, including in developing country settings displaying weak rule of law. Other design features strongly promoted by international NHRI templates, such as independence safeguards and broad promotional powers, may not correlate generally with more effective organizational outcomes across countries, but emerge as important under certain conditions, as evidenced in our case studies. More specifically, our case studies of Malaysia and the Philippines suggest that promotional powers can help an NHRI draw extensive publicity to human rights concerns. However, under inauspicious circumstances, and in the absence of other powers and safeguards, publicizing human rights concerns does not always suffice to prompt the executive to improve conditions on the ground, and can even lead to backlash. In the pages that follow, we outline the implications of our findings for major debates in the fields of administrative law, human rights, and international organization.

\section{A. Contributions to Administrative Law}

Should formal design occupy a privileged position in administrative law scholarship? Formal rules both constrain and enable independent agencies: they work both as a limit on permissible activities, and as a basis for justification of independent action. In the paragraphs that follow we present three mechanisms through which formal rules can influence outcomes, even in adverse circumstances, in which authoritarian regimes try to constrain independent agencies. First, we argue that formal rules have structured initial hiring and priority-setting, leading the NHRIs to emphasize some types of work over others, and perhaps limiting its own vision and ambition. Second, formal rules have shaped avenues of resistance to NHRI advocacy; opponents of the NHRI have been more likely to accede to NHRI efforts that clearly fall within its formal mandate, and more likely to challenge activities that are not clearly within the NHRI's mandates. Third, formal rules contribute to the generation of positive (and negative) feedback cycles over time, leading some NHRIs to develop deep-rooted societal support, while others face criticism for their limited efforts.

\section{How formal rules structure initial hiring and priorities}

Formal rules can have a powerful impact upon organizational identity, informing the way in which personnel perceive their institutional mission, professional duties, and relationship to diverse constituencies. We observe that formal rules have exerted an influence over NHRI staff actions early on, by shaping the NHRI's self-understanding of its role, its priorities, and its staffing needs. For example, in Peru, NHRI staff understood a broad complaint-handling mandate as enabling, whereas in Chile, NHRI staff understood a narrow complaint-handling mandate as a constraint. ${ }^{293}$ Whereas Peruvian officials were happy to accept a broad range of complaints, including for relatively small matters such as errors in water bill calculations, Chilean officials felt obliged to turn down many serious complaints that did not reach the torture threshold. This straightforward, if somewhat rigid, interpretation of a narrow legal mandate,

\footnotetext{
${ }^{293}$ See supra Parts III.B. and III.C.
} 
shows Chilean NHRI officials constraining themselves even before any opposition that they were overreaching could emerge.

While formal rules often demarcate limits and prescribe certain actions as required or impermissible, formal rules can also shape conduct within these limits by serving as guidelines for desirable behavior. Contrast the early years of the Malaysian NHRI, whose formal mandate included promotional powers, with the early years of the Philippine NHRI, whose formal mandate lacked many of these powers. In these early years, the Malaysian NHRI issued several hard-hitting reports that garnered very high publicity, while the Philippine NHRI defaulted into a low publicity strategy. They only hired one staff member with educational outreach expertise, instead focusing on hiring lawyers, guided in part by a formal mandate that explicitly granted the NHRI investigatory powers, but was silent on important promotional tasks. Because its guiding charter and leadership focused on prosecutions, not publicity, the Philippine NHRI remained relatively quiet in its early years, wasting a valuable window of opportunity in which Corazon Aquino emphasized human rights abuses perpetrated by her predecessor.

\section{How formal rules structure resistance strategies}

We argue that formal rules have also influenced the forms that resistance take to independent agencies tasked with holding government to account. Many formal NHRI safeguards focus on NHRI independence; when these are lacking, governments can undermine the entire NHRI structure. For instance, the Malaysian NHRI's hard-hitting reports provoked widespread criticism from the government. In addition to criticizing individual reports, Malaysian leaders did not reappoint particularly troublesome commissioners, in part because this was permitted by the NHRI's formal design - the unusually short two-year terms found in the Malaysian NHRI's charter coupled with the authority of the prime minister to recommend members. ${ }^{294}$ However, notably, retaliatory action in this case would rebound against the government when a powerful coalition of NHRI supporters successively lobbied for term limits to be extended in 2008, as part of a significant structural reform package.

Formal design features often place specific activities within an NHRI's mandate. Absent explicit authorization, ambitious NHRI heads can see their efforts stymied when they act in ways that can be challenged as exceeding their mandate. For instance, the Philippine NHRI lacks a broad-ranging promotion mandate. When an enterprising commissioner started campaigns to fight the evictions of street vendors, the Supreme Court held that the NHRI had exceeded its mandate, and should instead "focus its attention to the more severe cases of human rights violations." 295

\section{How formal rules contribute to positive and negative feedback loops}

By shaping the choices of agency advocates and opponents from the earliest stages onward, formal rules contribute to the development of positive and negative feedback loops over time. ${ }^{296}$ Here we can contrast the broad complaint-handling powers granted to the Peruvian

\footnotetext{
${ }^{294}$ See supra text accompanying note 186.

${ }^{295}$ See supra text accompanying notes at 268-69.

${ }^{296}$ For an in-depth account of feedback loops in constructivist and acculturation models of human rights, see Ryan GoOdman \& DereK Jinks, Socializing States: Promoting Human Rights through InTERnAtional LAW (2013).
} 
NHRI with the much narrower powers granted to the Chilean NHRI. As the case study material shows, complaints started to trickle in early on to the Peruvian Ombudsman, but as they received some form of resolution, and considerable publicity, their annual volume grew dramatically, to over 130,000 in 2016. In addition, the NHRI received a lot of positive press coverage. As a result, an attempt by the political elite to capture the NHRI in 2013 was met with street protests from Peruvians who placed their trust in this one responsive institution. ${ }^{297}$

In turn, not only was the Peruvian NHRI's budget not cut, but it increased over time to accommodate its growing caseload, increasing from \$4.4 million in 2000 to \$18 million in 2016. In addition, the Peruvian NHRI has changed widespread attitudes toward the state. By offering access and redress to individual citizens and by publishing statistics on other parts of the government that were quick (or embarrassingly slow) to address citizen problems, the NHRI allowed Peruvians to envision the possibility of an accountable bureaucracy. That said, following the 2016 democratic elections, with Fujimori supporters effectively taking control of the legislature via a supermajority, the NHRI was dealt a significant blow with the appointment of an individual as ombudsman with alleged links to the political elite. In short: a robust formal mandate enhances, but does not guarantee, the prospects that an NHRI will build support and resist challenges over time.

Contrast the success of the Peruvian NHRI with the difficulties encountered by the Chilean NHRI. Because of its narrow mandate, the Chilean NHRI acted upon few complaints. This lack of action on complaints was then used by Chilean legislators as the basis to cut the NHRI's budget; it was widely portrayed as either ineffectual or duplicating the function of other state agencies, and had struggled to build broad-based, plural domestic support. Indeed, even among expected supporters, such as human rights advocates, we observe resistance. Human rights observers highlight how the NHRI has been hamstrung by formal constraints, and have lobbied for the creation of competing bodies with complaint-handling powers-specialized bodies such as a children's ombudsman. The INDH itself rejected its official designation as the National Preventive Mechanism under OPCAT in 2010 due to formal shortcomings. In short, initial formal mandates can end up having significant long-term effects on agency integrity and performance.

\section{B. Bringing Human Rights into Administrative Law Scholarship}

We also contribute to administrative law scholarship by highlighting the distinct operation of formal design in the human rights field. Unlike issue-areas such as public utilities, environmental, or antitrust regulation, that are generally modeled as games between three players - the state, the regulator, and the firm - human rights pose a different regulatory challenge. International human rights treaties often pit the interests of the authorizing principal (individual states and their officials) against the regulator (the NHRI). The risk of regulatory capture is thus particularly acute in the human rights field; we are not worried that a regulated industry will capture the regulator, but we are worried that the regulated executive and legislative branches will capture the regulator. ${ }^{298}$ To clarify: human rights violations are often perpetrated by the government itself, and are often authorized by top leaders in the state's most powerful branches, including the executive, the police, and the military. Constraining an autocrat or a top

297 See supra text accompanying note at 147.

298 Tom Pegram, Regulatory Stewardship and Intermediation: Lessons from Human Rights Governance, 670 ANNALS AM. ACAD. POL. \& SOC. SCI. 225, 233-34 (2017). 
military commander might be even harder than the typical challenge outlined in the capture literature-i.e. limiting the influence of a politically powerful utility company, mining company, or pharmaceutical company. This study expands the substantive boundaries of administrative law to the human rights arena, to interrogate design effects in this regulatory setting, a setting that displays unusual delegation arrangements as well as high distributive and value conflict. ${ }^{299}$

\section{Implications for human rights scholarship}

In turn, the study extends the predominant focus in administrative law on advanced industrialized countries to assess what happens to supposedly stable assumptions surrounding formal effect when regulatory innovations travel to developing country settings. Our quantitative findings show that formal rules matter most in democratic settings, but also have some effects in authoritarian states. And our case studies elaborate on why formal rules still have some purchase even in transition states and under authoritarian conditions.

This insight also bears on a lively debate in the human rights compliance literature. ${ }^{300}$ Consistent with Simmons's observation that treaty ratification has its largest effects in democratizing regimes as opposed to stable democracies or autocracies, ${ }^{301}$ we document high compliance effects, mediated by effective domestic mechanisms, in transitional settings. However, we add some nuance to understanding regime-specific treaty effects. First, we highlight variation in treaty effects via NHRI impact within transitional regime settings. This likely reflects the heightened sensitivity of domestic compliance mechanisms, as opposed to international instruments, to prevailing local institutional environments. ${ }^{302}$ Second, our Chilean case study suggests that treaty ratification may have limited effects in stable democratic settings, not only because the bar is already set high in terms of human rights protection, but because robust rule of law frameworks serve to mask isolated, but significant, human rights protection deficits, especially for vulnerable and marginalized groups within society Third, our findings highlight some significant, albeit circumscribed, openings for domestic treaty effects even under authoritarian conditions. However, it is important to note that our cases are not "stable autocracies." As we have documented elsewhere, NHRIs established in dictatorships, such as Bahrain, Iraq, and Saudi Arabia, are invariably governmental façade human rights bodies. ${ }^{303}$

\section{Implications for human rights practice}

This article also highlights the direct policy implications of human rights scholarship: explaining how specific institutional design safeguards have helped to empower NHRIs and constrain unchecked authoritarian governments' abusive practices. In particular, we find that

299 See Sean Gailmard, Politics, Principal-Agent Problems, and Public Service Motivation, 13 INT'L PUB. MGMT. J. 35 (2010).

${ }^{300}$ See Geoff Dancy \& Christopher J. Fariss, Rescuing Human Rights Law from International Legalism and its Critics, 39 HuM. RTS. Q. 1-36 (2017).

${ }^{301}$ See SIMMONS, supra note 2.

302 See Jana von Stein, Making Promises, Keeping Promises: Democracy, Ratification and Compliance in International Human Rights Law, 46 BRIT. J. POL. SCI. 655-79 (2016) (importance of credible domestic enforcement in mediating treaty effects).

303 See Linos \& Pegram, The Language of Compromise, supra note 7, supplementary material at https:/www.cambridge.org/core/journals/international-organization/article/the-language-of-compromise-ininternational-agreements/873071FBCA998D07A3FB96DB96120782\#fndtn-supplementary-materials. 
while some formal design features operate differently across contexts, others, and especially investigative prerogatives, are important in a broad range of settings. This section highlights the effect of two specific safeguards in more depth: complaint-handling and promotion powers.

We find very robust support for our conjecture that complaint-handling powers contribute to NHRI effectiveness in both democratic and authoritarian settings. As we outline in our theory, to date complaint-handling has been a controversial aspect of NHRI structures. Prominent critics worry that individual complaints can easily overwhelm small agencies, and direct their energies away from grave, systematic abuses toward small-bore problems of relatively well-positioned individuals. We find however, that complaint-handling is a very powerful tool, because it allows NHRIs to offer direct redress to individuals alleging violations and thus to make at least one part of the state accessible and responsive to its inhabitants.

We also illustrate the ability of NHRIs to convert political capital derived from effective handling of individual complaints into a powerful base of public support. The importance of public support in the work of the NHRI echoes recent research on the ability of international judges to influence state behavior, spotlighting the importance of diffuse support among domestic and international interlocutors in subordinating powerful actors to the rule of law. 304 We also document positive feedback effects, including rising complaints serving as a justification for budget increases. These findings are compatible with other research that highlights the importance of complaint reception for torture prevention across sixteen country studies, especially when coupled with express authority to refer complaints to prosecutors. ${ }^{305}$

In turn, the significance of promotional powers, especially for NHRIs operating in hostile settings, reinforces recent calls in the scholarship for a reappraisal of non-coercive managerial strategies of influence which might slowly yield important results over time. ${ }^{306}$ In the short term, promotional work can succeed in getting human rights issues onto the national agenda. However, this alone is only a first step: it is telling that the Malaysian NHRI, which has expansive promotional powers but few other safeguards, is often criticized for failing to turn major publicity into concrete policy reform. ${ }^{307}$ Nevertheless, establishing a gap between expectations and official practice may in itself prove beneficial to mobilization and efforts to force the government's hand over time.

These findings also have significant policy implications. The international standards governing NHRI design, the Paris Principles, strongly recommend that all NHRIs include promotional powers, but only weakly recommend complaint-handling. ${ }^{308}$ It is unlikely that the Paris Principles will be redrafted to include a recommendation that all NHRIs have complainthandling powers. This is because advocates worry that the reopening of negotiations on the Paris Principles could lead to a weakening of the document. ${ }^{309}$ Nevertheless, as we recommend below, the GANHRI SCA, the UN-affiliated NHRI peer review mechanism, offers an alternative route toward placing pressure on governments to maintain complaint-handling powers where NHRIs already exist, and build them into existing or soon to be established national institutions.

\footnotetext{
304 See Karen Alter, The New Terrain of International Law: Courts, Politics, Rights (2014).

305 See Richard Carver \& Lisa Handley, Identifying What Preventative Mechanisms Work, in DoES TORTURE PREVENTION WORK? 90 (Richard Carver \& Lisa Handley eds., 2016).

306 INTERDISCIPLINARY PERSPECTIVES ON INTERNATIONAL LAW AND INTERNATIONAL RELATIONS: THE STATE OF THE ART (Jeffrey L. Dunoff \& Mark A. Pollack eds., 2013).

${ }^{307}$ See supra text accompanying notes 192-93, 202.

308 For further insight into the negotiations which informed the Paris Principles see Linos \& Pegram, The Language of Compromise, supra note 7.

${ }^{309}$ MORTEN KJÆRUM, NATIONAL HUMAN RightS INSTITUTIONS IMPLEMENTING HUMAN Rights 9 (2003).
} 


\section{Contribution to Debates on International Organizations}

The question of NHRI organizational effectiveness also poses a direct challenge to the credibility of their principle supporter: the United Nations. The UN human rights apparatus finds itself embattled - at the mercy of obstructive member states, saddled with dwindling resources, and enjoying few effective policy tools to directly enforce human rights protections, especially where these are needed most. ${ }^{310}$ Persistent violating behavior by "false positives," states that commit to UN treaties with no intention of complying, threaten to bring the entire system into disrepute. ${ }^{311}$ In response, the United Nations has sought to strengthen a diverse body of global administrative human rights law, exemplified by more intrusive norm frameworks, enhanced access to UN procedures, and the formal coordination of dedicated institutional mechanisms at the national level. ${ }^{312}$ NHRI promotion and strengthening forms a key plank of an ambitious UN strategy of compliance via orchestration. ${ }^{313}$ This development in global regulatory governance reflects an often underappreciated trend toward international organizations taking a lead in changing "the international sources of law, their substantive content, and the actors that make them, including states themselves." 314

Against a challenging backdrop, the diffusion of NHRIs around the world marks a big success for the United Nations. Almost 120 countries now have NHRIs, and the vast majority of these closely follow the UN-sponsored Paris Principles. ${ }^{315}$ Moreover, the United Nations has begun building on the success of NHRIs by giving NHRIs formal speaking rights and incorporating them into treaty structures - notably as national preventive mechanisms under the OPCAT. ${ }^{316}$ The establishment of ex novo structures has also set in motion important design feedback effects, serving as a focal point for mobilizing compliance levels above an expected baseline, as witnessed in Malaysia with the upgrading of Suhakam's structure in line with the Paris Principles in 2009. However, conversely, the influence of an international template may also have fueled a perverse "race to the middle," with advocates for a more robust protective Chilean NHRI in line with the regional norm undermined by the basic NHRI model, as endorsed by the United Nations. ${ }^{317}$ Despite concerns about the (sub)optimality of the international template, the very fact that an Assembly resolution shaped the form of administrative agencies around the world is a major support for theories suggesting that the United Nations can wield important influence as a norm entrepreneur.

At the same time, the ultimate test of United Nations' influence does not concern the diffusion of NHRIs, but the diffusion of effective NHRIs. After all, a large literature in sociology

\footnotetext{
310 See HAFNER-BURTON, supra note 83.

311 See SIMMONS, supra note 2.

${ }^{312}$ Kingsbury, Krisch \& Stewart, supra note 9. See also Nico Krisch, The Pluralism of Global Administrative Law, 17 EUR. J. INT'L LAW 247-78 (2006).

313 See Tom Pegram, Global Human Rights Governance and Orchestration: National Human Rights Institutions as Intermediaries, 21 EUR. J. INT'L RELATIONS 595 (2015); Pegram, Regulatory Stewardship and Intermediation, supra note 298.

314 See José E Alvarez, INTERNATIONAL ORGANIZATIONS AS LAW-MAKERS 588 (2005).

${ }^{315}$ Linos \& Pegram, The Language of Compromise, supra note 7, at 615.

${ }^{316}$ Linos \& Pegram, Architects of Their Own Making, supra note 8, at 1110; Pegram, Regulatory Stewardship and Intermediation, supra note 300, at 298.

317 GOODMAN \& JINKS, supra note 298.
} 
suggests that formal design is often decoupled from actual functions. ${ }^{318}$ By showing that formal design features are in fact connected to greater effectiveness, this study documents a particularly strong influence of the United Nations. Formal rules have provided NHRI practitioners and their supporters with a rare lever of influence over instituting structures at the national level, but as noted, adopting states retain significant prerogatives over the resulting NHRI form, as well as the individuals who populate the organization.

The United Nations has few levers other than formal design recommendations to influence NHRI behavior-for instance, it cannot directly appoint NHRI staff members, or contribute significantly to NHRI financing. This greatly increases the importance of issuing the correct formal design recommendations. ${ }^{319}$ As our analysis shows, the formal design safeguards we studied are most closely linked with NHRI effectiveness in democratic states. This raises an important question for further research: is any formal design recommendation more likely to work in democratic settings, simply because these states tend to follow the rule of law more generally? Or are we basing our design safeguards too heavily on what works in industrialized countries, and a different set of safeguards would be more likely to work in developing country settings?

Our study highlights one particular limitation of the UN-promoted Paris Principles - the de-prioritization of protective functions, and especially complaint-handling powers. How can one best ensure that the UN template is updated in light of current knowledge? Amending the Paris Principles seems unlikely; a large literature on international agreements suggests that these are quite sticky. While binding agreements can be particularly hard to modify, even amending a nonbinding agreement, such as the General Assembly resolution creating the Paris Principles, would require significant efforts to reach consensus among diverse UN members, and NHRI advocates worry that in the process, key recommendations might be watered down. However, another avenue for reform seems promising: the SCA, the peer review monitoring mechanism that grades NHRIs. Lacking a direct means to implement policy, the UN system has strongly promoted the role of the SCA as a third-party monitor of NHRI design integrity and performance. Delegation of monitoring duties to a third party can enhance compliance, especially where - as is the case of the SCA - a central body collects information from diverse sources and issues highly specific assessments in the form of letter grades to individual NHRIs. ${ }^{320}$ In recent years, the SCA has sought to ratchet up the specificity of the Paris Principles still further through authoritative interpretations. ${ }^{321}$

A growing literature on indicators suggests that ranking mechanisms are very powerful levers, as they help focus the attention of key decision-makers as well as broader audiences. ${ }^{322}$

318 See Katerina Linos, The Democratic Foundations of Policy Diffusion: How Health, Family, And EMPloyment LAws SpREAD Across Countries 13-35 (2013); Ryan Goodman \& Derek Jinks, How to Influence States: Socialization and International Human Rights Law, 54 DUKE L.J. 621 (2004).

319 This finding echoes research on treaty design effects highlighting the important distinction between precise but shallow commitments that require specific but insignificant departures from the status quo, and commitments that are both precise and deep, requiring states to take specific actions that significantly depart from what they would otherwise do. See Kal Raustiala, Form and Substance in International Agreements, 99 AJIL 581 (2005).

${ }^{320}$ Kenneth W. Abbott \& Duncan Snidal, Hard and Soft Law in International Governance, 54 INT'L ORG. 421, 428-29 (2000).

${ }^{321}$ International Co-ordinating Committee of National Institutions for the Promotion and Protection of Human Rights, ICC Sub-Committee on Accreditation General Observation (May 2013), available at http://nhri.ohchr.org/EN/AboutUs/Governance/Documents/ICC\%20SCA\%20General\%20Observations.pdf.

322 See Governance By IndiCATORS, Global POWER Through QUANTIFICATION AND RANKINGS (Kevin Davis, Angelina Fisher, Benedict Kingsbury \& Sally Engle Merry eds., 2012); Judith G. Kelley \& Beth A. 
Indeed, we have seen such transformations before; as one Malaysian commissioner indicated, the threat of downgrade led the Malaysian government to greatly expand the NHRI's powers. In his words, "[i]n hindsight, B stands for blessing in disguise." ${ }^{323}$ More generally, it is not unusual to have human rights courts and committees interpret the meaning of foundational documents progressively, and in so doing maintain their continued relevance..$^{324}$

We therefore end our study on an optimistic note. In developing the Paris Principles, the UN General Assembly used its principle leverage tool-normative influence-with far more specificity than is typical. In so doing, it triggered global diffusion of administrative agencies with highly specific safeguards. Many of these safeguards, we have found, contribute to greater NHRI effectiveness around the world, even in hostile contexts. While formal safeguards are not, in themselves, sufficient to bring about change, they can be of significant help, by structuring initial hiring and priorities, by reshaping resistance, and by triggering positive feedback loops.

Simmons, Politics by Number: Indicators as Social Pressure in International Relations, 59 AM. J. POL. SCI. 55 (2015).

323 Tan Sri Hasmy Agam, Chairperson, Malaysian Human Rights Commission (Suhakam), Strengthening National Human Rights Institutions: The Paris Principles and the ICC Accreditation System, Presentation at the Geneva Side Event on Accreditation (Mar. 21, 2012); see also ThOMAS PEGRAM, BRIDGING THE Divide: The

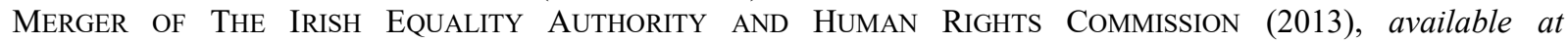
https://www.tcd.ie/policy-institute/assets/pdf/Studies_Policy_29_web.pdf.

${ }^{324}$ Laurence R. Helfer \& Erik Voeten, International Courts as Agents of Legal Change: Evidence from LGBT Rights in Europe, 68 INT'L ORG. 77, 85 (2014). 